\author{
LOCATING DISABBILITY: \\ People with Disabilities, their Movements and the Canadian Federal State \\ by \\ Fraser Cornell Valentine, BA (Hons.)
}

\begin{abstract}
A thesis submitted to
the Faculty of Graduate Studies and Research

in partial fulfilment of the requirements for the degree of
\end{abstract}

Master of Arts

in Canadian Studies

Carleton University

OTTAWA, Ontario

April 2, 1996

(C)copyright

1996, Fraser Valentine 
Natıo?al Library

of Canacia

Acquisitions and

Bibliographic Services Branch

395 Weslington Street

Ontawa, Ontario

K1A ON4
Bibliothèque nationale

du Canada

Direction des acquisitions et

des services bibliographiques

395. rue Wellington

Otrawa (Ontario)

Your the Votre reterence

Our five Norre seterence

The author has granted an irrevocable non-exclusive licence allowing the National Library of Canada to reproduce, loan, distribute or sell copies of his/her thesis by any means and in any form or format, making this thesis available to interested persons.
L'auteur a accordé une licence irrévocable et non exclusive permettant à la Bibliothèque nationale du Canada de reproduire, prêter, distribuer ou vendre des copies de sa thèse de quelque manière et sous quelque forme que ce soit pour mettre des exemplaires de cette thèse à la disposition des personnes intéressées.

L'auteur conserve la propriété du droit d'auteur qui protège sa thèse. Ni la thèse ni des extraits substantiels de celle-ci ne doivent être imprimés ou autrement reproduits sans son autorisation.

ISBN $\quad 0-612-13822-4$ 
Name fruser Cornell Valentine

Dissertation Abstracts International is arranged by broad, general subject categories. Please select the one subject which most nearly describes the content of your dissertation. Enter the corresponding four-digit code in the spoces provided.

\section{Canadian Studies}

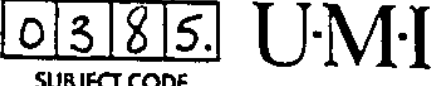

SUBEECT CODE

\section{Subject Categories}

\section{THE HUMANITIES AND SOCIAL SCIENCES}

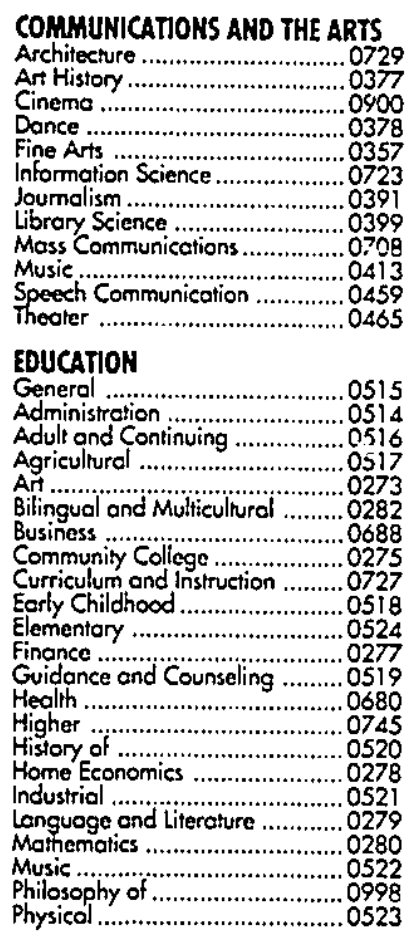

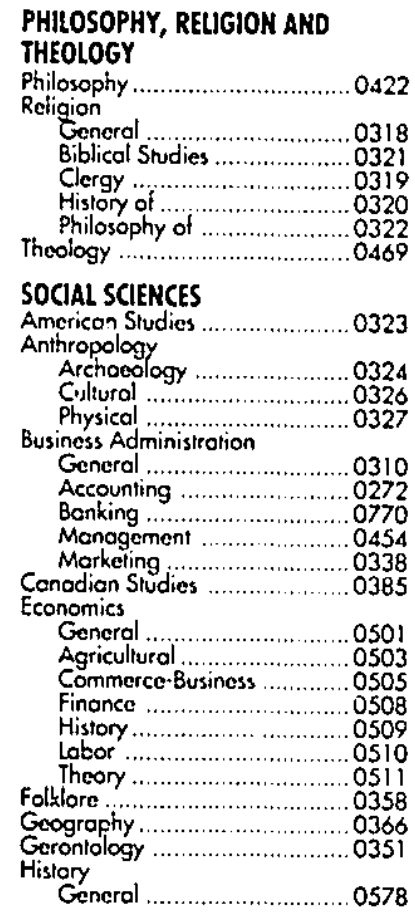

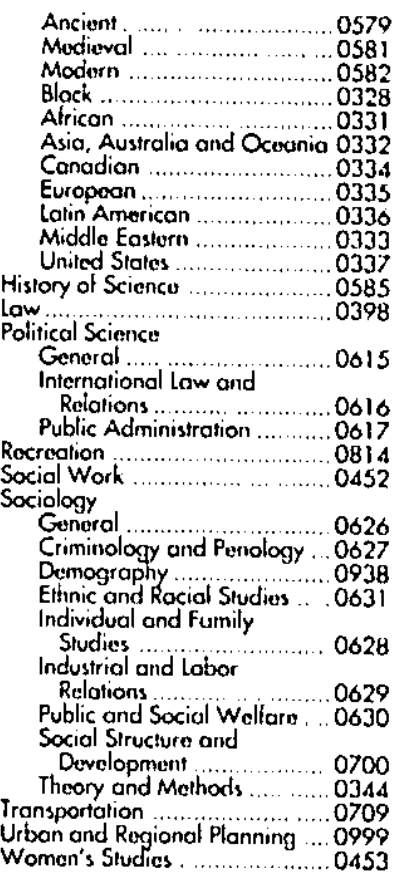

\section{THE SCIENCES AND ENGINEERING}

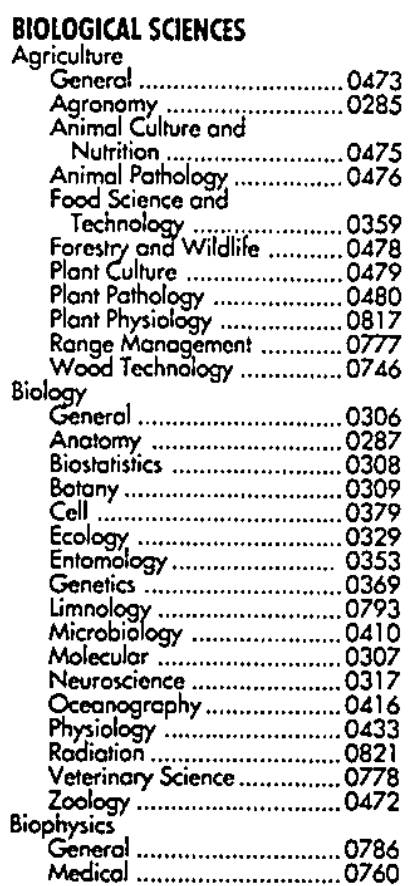

EARTH SCENCES

Biogeochemistry 0425

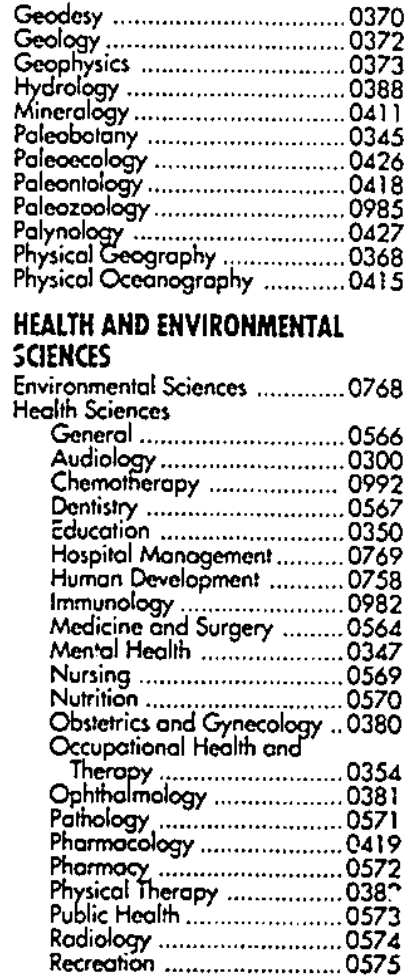

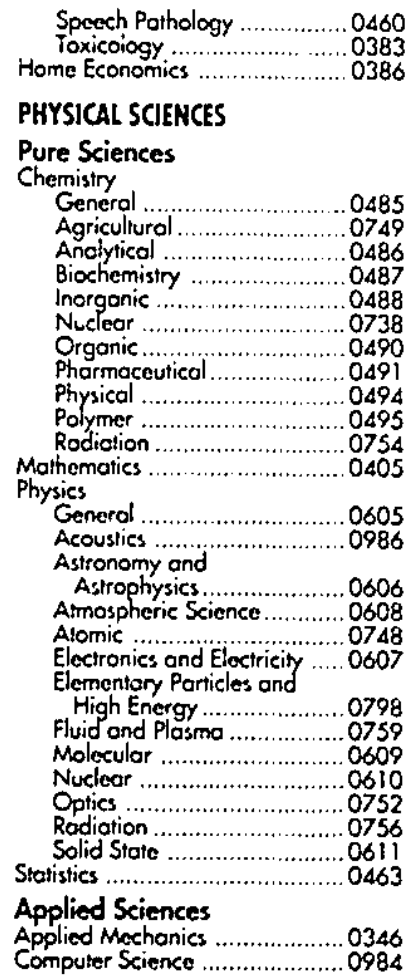

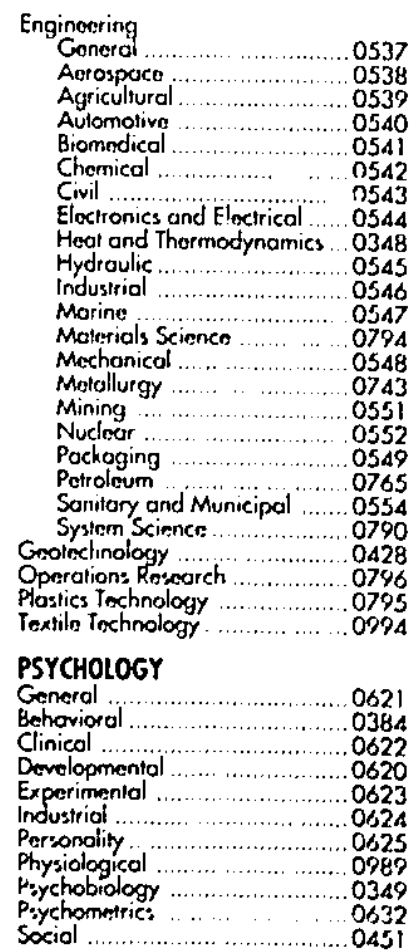


Thesis accompanied by 5 tapes which cannot be microfilmed. The hardcopy of the thesis is available upon request from Carleton University Library. 
The undersigned recommend to the Faculty of Graduate Studies and Research acceptance of the thesis

\begin{abstract}
"Locating Disability: People with Disabilities, their Movements and the Canadian Federal State"
\end{abstract}

submitted by Fraser Cornell Valentine, B.A. Hons. in partial fulfilment of the requirements for the degree of Master of Arts
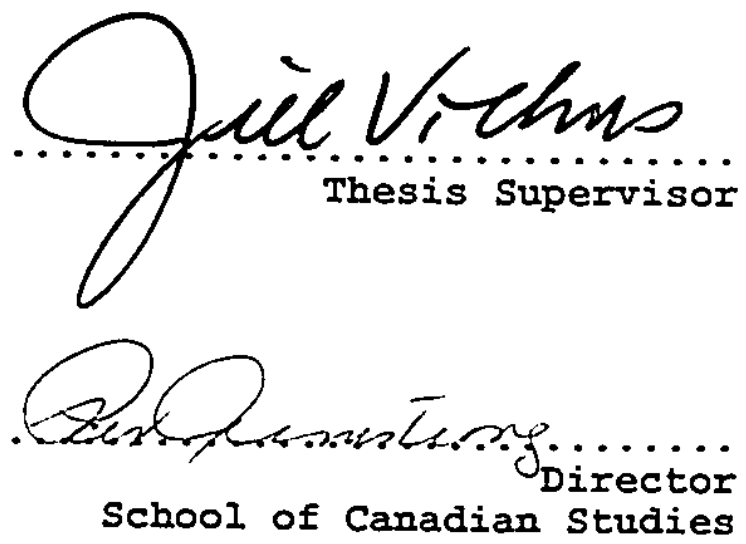

\author{
Carleton University \\ Ottawa, Ontario \\ May 1996
}


For my father,

Sandford Dolse Valentine 1929-1991 


\section{ABSTRACT}

To date, disability movements have been little studied and undertheorized by academic knowledge systems. This investigation is an attempt to begin the process of redressing these gaps. It focuses on the development of organizations by people with disabilities themselves which emerged in the 1970s to challenge the widely-held view that PIVDs are passive, 'sick', and political inactive; that is, not citizens.

By focusing on the self-knowledge of PWDs, this study traces the development of Canadian disability movements at the federal level, especially the Independent Living movement. Using a comparative analysis and through an examination of the political environments in which disability movements emerged this study argues that disability organizing has been influenced by factors unique to Canada. In particular, this investigation focuses on the positive relationship between Canadian disability movements and the federal state highlighting the importance of Canadian federalism, federal state structures and apparatuses, as well as, Canada's vast territory, northern climate and sparse population towards the development panCanadian disability movements.

Note: This thesis is also available on alternate format. 


\section{ACKNOWLEDGMENTS}

I am grateful to the Board of Directors and staff at the Canadian Association of Independent Living Centres (CAILC). The opportunity to work at CAILC proved essential to the completion of this study. I would like to thank in particular, Muriel Keeling (Calgary ILRC), Allan Simpson (Winnipeg ILRC), Henry Enns (DPI), and Traci Walters (CAILC) who challenged and supported my work throughout this process. As well, thanks to the many individuals involved in the IL movement who live throughout Canada. I'm proud to say that I have made many friends as a result of this project. Next, my thanks to Linda Brown and Luna Bengio from Human Resources Development Canada (HRDC) for making their files accessible to me. Finally, special thanks to Diane Driedger for her insight concerning the history of disability movements in Canada. Without Diane's unpublished research, this study would have been incomplete.

I am indebted to my supervisor Professor Jill Vickers, whose support and constant guidance have ensured that my work always reached the highest possible standard. Jill taught me how to research with integrity, borrow "respectfully" and "respectably" and write with precision. Although at times I didn't think I could accomplish all she expected me to, Jill nevertheless consistently provided me with opportunities to advance my academic pursuits. Thanks for everything Jill.

Writing this thesis often seemed insurmountable. During the many times in which I thought I could not and would not accomplish this task several individuals came to my rescue. Heather Webb, Victoria Angel and Katherine Manson collectively sat though many hours of what at the time seemed important, but in retrospect seems predictable. Pat Gentile has also offered support in more ways than I can describe. I certainly know we'll aiways be able to laugh together. Thanks also to the many individuals involved in the New Politics Project. Of course, my thanks to Michael-who came into my life mid-way through this process. I don't think he had/or has any idea what he's gotten himseif into.

Finaliy, my thanks to Pauiine Rankin, who has supported me both academically and personally since 1989 . Finding the words to express my friendship with Pauline is impossible. Over the years, I have attributed many roles to Pauline-teacher, mentor, colleague and friend. No matter which role, Pauline has always been a source of inspiration. Without her continued support (in both my personal and academic life), I am certain I would not have made it this far. Thanks, Pauline. 


\section{TABLE OF CONTENTS}

Abstract

Acknowledgments

List of Tables

List of Figures

Abbreviations

\section{INTRODUCTION}

Locating Disability:

People with Disabilities, their Movements and the Canadian Federal State

Purpose and Objective

Relevance of the Investigation

Overall Approach of the Investigation

Methodological Approach

Chapter Outlines

Notes

\section{CHAPTER ONE}

Disability Movements in Canada:

Identity, Citizenship and the Challenge of Disability

Introduction

People with Disabilities and Identity Politics

The Meaning of Disablement:

The Role of Modern Medicine and Social Science Research

People with Disabilities and the Politics of Citizenship

The Contemporary Welfare State and 
The Disability Rights Movement and

the Push to be Self-Defined 44

$\begin{array}{ll}\text { Conclusion } & 48\end{array}$

$\begin{array}{ll}\text { Notes } & 50\end{array}$

\section{CHAPTER TWO}

Disability Movements in Canada:

Making Choices, Choosing Strategies

Introduction

Disability Organizing in Canada:

Sketching the Periods of Mobilization

The Post-Medicalization Period:

An Historical Overview of Disability Organizing in Canada

Historical Overview of Disability Organizing

in the United States

The Same; but Different:

Transplanting the U.S. IL Movement into

Canadian Disability Organizing

Conclusion

Notes

\section{CHAPTER THREE}

Initiatives and Responses:

The Federal State and Disability Movements Since 1970

Introduction

Grounding Disability Movements in "Canadian Realities:"

Canadian Treatments of Movement Theory

Setting the Context:

The Canadian Federal State and Movements of

Persons with Disabilities 
Contradictory Actions:

The Federal Government's Response to the

Disability Movement Since 1980

A Case Study:

Federal Support for Independent Living in Canada 152

$\begin{array}{ll}\text { Conclusion } & 167\end{array}$

$\begin{array}{ll}\text { Notes } & 169\end{array}$

\section{CONCLUSION}

Disability Movements, the Canadian Federal State and the Future

An Overview of the Investigation 173

Key Findings of the Investigation $\quad 175$

Suggestions for Future Research 182

\section{APPENDICES}

Appendix A

183

Appendix B

BIBLIOGRAPHY 


\section{LIST OF TABLES}

TABLE 1 Historical Periods in the Classification of Disability in Canada (1600s-present)

TABLE 2 Canadian and International Non-Governmental

Organizations Representing People with Disabilities

TABLE 3 Canadian Provincial Consumer Disability Organizations in the 1970s

TABLE 4 Provincial Members of the Council of Canadians with Disabilities (1995)

TABLE 5 Comparison of Rehabilitation and Independent Living Models

TABLE 6 Members of the Canadian Association of Independent Living Centres (1995)

TABLE 7 Organizations Representing Persons with Disabilities in the United States (Pre-1960)

TABLE 8 Advocacy-based Disability Organizations of Persons with Disabilities in the United States (Post-1960)

TABLE 9 Central Pieces of U.S. 'Civil Rights' Legislation Affecting Persons with Disabilities

TABLE 10 Initiatives Undertaken by the United Nations Concerning People with Disabilities

TABLE 11 Central Focuses of the Citizenship Branch in the Secretary of State (1945-1989)

TABLE 12 Summary of Parliamentary Actions Concerning Persons with Disabilities

TABLE 13 Highlights of Federal Government Initiatives Affecting Persons with Disabilities Since 1980

TABLE 14 Grants and Contributions by the Disabled Persons Participation Program (1981-1997) 
TABLE 15a Funding Under the NSIPD by Federal Department and Agency (at time of Treasury Board 1991 decisions)

TABLE 15b Funding Under the NSIPD by Federal Department and Agency (after the 1993 restructuring of the federal bureaucracy)

TABLE 16 Federal Disability Initiatives which are Under Review or Slated for Elimination

TABLE 17 Roles and Responsibilities of the 'Special Initiative' Partners as Defined in the Terms of Reference 


\section{LIST OF FIGURES}

FIGURE 1 Dimensions of Disablement 22

FIGURE 2 Schematic of the Goal of the 'Special Initiative' 162 


\section{ABBREVIATIONS}

CAILC

CAP

CHST

CIDA

CiL

$\mathrm{COPOH} / \mathrm{CCD}$

DAWN

DPI

DPPP

EPF

HRDC

IL

ILC

ILRC

IYDP

NAC

NAND

NHW

NSIPD

PWDs
Canadian Association of Independent Living Centres

Canada Assistance Plan

Canada Health and Social Transfer

Canadian International Development Agency

Centre for Independent Living

Coalition of Provincial Organizations of the Handicapped/Council of Canadians with Disabilities

DisAbled Women's Network

Disabled Persons International

Disabled Persons Participation Program

Established Programs Financing

Human Resources Development Canada

Independent Living

Independent Living Centre

Independent Living Resource Centre

International Year of Disabled Persons

National Action Committee on the Status of Women

National Aboriginal Network on Disability

Department of National Health and Welfare

National Strategy for the Integration of Persons with Disabilities

People with Disabilities 
POS

SDPS

SOS

UN

UNDDP

VRDP

WPA
Political Opporiunity Structure

Status of Disabled Persons Secretariat

Department of the Secretary of State

United Nations

United Nations Decade of Disabled Persons

Vocational Rehabilitation for Disabled Persons

World Program of Action 


\section{INTRODUCTION}

\section{LOCATING DISABILITY: \\ People with Disabilities, their Movements and the Canadian Federal State \\ I}

\section{Purpose and Objective}

This thesis is a study of disability organizing in Canada through an examination of the Canadian Independent Living (IL) movement. Investigations into critical movements for change are not uncommon in the social sciences. U.S., European and some Canadian scholars, for example, have undertaken considerable research examining the impact on civil socicty of the women's, visible minority, ecological, peace, anti-poverty and to a lesser extent gay/lesbian movements. In general, this literature is sociological and interested in uncovering the nature of the movement actors (identity formation approach $)^{1}$ or the kind of environment which fosters movement activism (resource mobilization approach). ${ }^{2}$ Only recently have social scientists begun to investigate the way in which movements intersect and transform the political terrain. In this effort, Canadian experiences have been especially informative.

Critical movements for change or simply, movement politics are often referred to as 'new' social movements in European literature or alternatively 'social' movements in U.S. investigations. In this study, I reject both these terms and instead I adopt the term "critical movements for change" because I maintain, with Doug McAdam (1988), that referring to movements as 'social' delegitimizes their activities as political forces in society and because many critical movements are not 'new' in the European sense of being either 
counter-hegemonic or post-materialist. Instead, I argue that the term "critical movements for change" correctly encompasses both an understanding of movements as having both political and social meaning. Focusing on critical movements as political actors is important; indeed, Canadian political scientist Susan Phillips argues that movements have "a profound impact on the conduct and consequences of politics in Canada" (1994: 188).

Although there are now significant investigations concerning the politics of the ivomen's and First Nations movements in Canadian movement literature, ${ }^{3}$ the contemporary disabled persons' movement continues to be ignored. Disability is treated, if at all, as an 'add-on' to existing theoretical models designed to account for movement activity in Canada. Similarly in the U.S. and Europe, disability movements are virtually ignored. In Canada, two books have been written on Canadian disability groups; Diane Driedger's historical account of Disabled Peoples' International, The Last Civil Rights Movement (1989) and René Gadacz's sociological analysis of the Canadian consumer disability movement, Rethinking Disability $(1994)^{4}$. The political strategies, techniques and relationships of disability groups to one another, to other types of movement groups (e.g., women) and most important, to the Canadian state continue to be overlooked. This is somewhat ironic in studies that are often called 'new' social movements since of all movements studied, disability movements are genuinely 'new'. Most other critical movements for change are 'old', with initial waves of mobilization as early as the $1880 \mathrm{~s} .^{5}$

I have two primary objectives in this thesis. First, my aim is to contribute to the process of redressing the absence of material within movement scholarship on issues relating to the Canadian disability rights movement; second, I want to challenge the widely-held view that people 
with disabilities (PWDs) are passive, 'sick' and politically inactive; that is, not citizens. For reasons explored below, I have chosen to focus this study on the development of the Canadian Independent Living movement and its panCanadian organization, the Canadian Association of Independent Living Centres (CAILC), especially in its interaction with the Canadian federal state. This study is not an investigation of PWDs and their relationship to the medical community, but rather it addresses the more fundamental question of the reiationship PWDs have to Canadian society and to state institutions as autonomous poilitical actors.

\section{II}

Relevance of the Investigation

Canadian political scientist Susan Phillips argues that "[t]he international dimension of social movements has served to connect Canadians to peoples around the world because movements tend to promote a concept of citizenship as global, meaning that certain rights are regarded as universal in nature and should not be abrogated by any government" (my emphasis, 1994: 188). While Phillips' observation is useful, it nonetheless raises some interesting questions about the extent to which movements are grounded by space and time. In other words, as argued in 'new' social movement literature, do movements present "a global agenda" for participatory democracy or are their actions directly informed by the context from which they exist?

Although more research is being undertaken in this area, there remains a dearth of material in the social sciences to assist us in unraveling this important question. To that end, my investigation contributes to this field of research. I argue in this thesis that advocating a common global 
pattern of movement activism ignores, first, the heterogeneity of movements for change and perhaps more importantly, it ignores the impact of different states in shaping movements. By comparing Independent Living in Canada and the U.S., I will show that movements do not take a common form globally. Instead, political, economic and cultural differences result in considerable diversity among and between movements for change around the world despite some shared features and identities. This is similar to the findings of Vickers, Rankin \& Appelle who argue that "women's movements are shaped by the states in which they relate and by the political culture associated with those states" (1993: 18).

I will illustrate in this thesis that the Canadian disability movement is shaped by both the Canadian state and Canadian political culture by detailing how the IL. movement, which has its origins in the U.S. disability movement, changed as it crossed borders and began to operate in the Canadian federal political environment. Although the disability rights movement in Canada is relatively 'new', it is almost as multi-faceted and multi-layered as other older movements. The case study of the Canadian Independent Living movement will show the impact of the Canadian context on the character of the Canadian disabled persons' movement. Overall, this investigation offers six key findings:

- People with disabilities are political actors, but they cannot be so at the federal level without support from the government;

- Pan-Canadian disability movements, especially the Independent Living movement, were fostered by the federal state;

- The state-focused orientation of Canadian disability movements was positive for their development;

- The process of de-institutionalization of individuals has turned out to be more difficult than first anticipated; 
- Federalism, as well as, Canada's geography, territory, climate and sparse population impact movements, especially disability movements; and

- Neo-liberalism and de-centralization are significantly different processes.

\section{Why Focus on the Independent Living Movement?}

Diane Driedger's (1989) conceptual mapping of Canadian disability movements has influenced the focus and path of my investigation. 6 She argues that three branches or wings have been evident since the movement's emergence in the late 1960 s and 1970s-consumer disability organizations, the Independent Living movement and self-help groups (Driedger, 1989: 4). Consumer disability organizations monitor existing services provided to PWDs by governments, the medical community and rehabilitation services. As Driedger observes, they "assert that disabled persons have rights as citizens to services that enhance an independent living lifestyle" (1989: 4). Consumer groups advocate for PWDs wherever they and the services provided for them are located. Indeed, they advocate for the rise of a 'disabled consumer ethic' in which they emphasize their oppression o- marginalization as consumers of state services, rather than as workers in the labour market. ${ }^{7}$

The Canadian Independent Living movement rejects the rehabilitation paradigm and the medical model of disability as disease ${ }^{8}$ to offer a 'politicized' view of service delivery systems; that is, community-based systems in which PWDs are in control, not medical professionals. The movement embraces the 'disabled consumer ethic' and fights for accessible community-based services, as well as providing support, (some) services and skillsdevelopment training to individual PWDs living in the community. Selfhelp groups such as Alcoholics Anonymous emphasize self-reliance, but do not pursue a political agenda. They are primarily organized to achieve 
therapeutic goals and do not concern themselves with influencing other organizations, institutions or government. In this thesis, I focus on the IL movement and consumer disability organizations. I do not deal with selfheip groups whose approach is primarily self-focused and not involving social or political change.

Both the U.S. and Canadian Independent Living movements involve two components; a paradigm shift in service delivery modeis for PWDs and a political movement organized by persons with disabilities themselves. While the former has been given considerable attention in the human service disciplines (rehabilitation science, medicine), scant attention has been paid to the later. This political movement was 'invented' in the U.S. and was imported/transplanted to Canada. How has it changed in the process? What impact has it had on Canadian society and what impact has Canada had on Independent Living? What kind of relationship has the $\mathrm{IL}$ movement developed with the federal state and why? During this period of retrenchment of the welfare state, how will the $\mathrm{IL}$ movement position itself vis-à-vis the Canadian state? Why, for example, does Independent Living remain especially attractive to governments as a way of delivering state support to PWDs?

\section{A Brief History of Independent Living in Canada}

The Independent Living movement originated in the United States where, in 1972, the Berkeley Independent Living Centre was established by a group of students with disabilities. They realized that, once they graduated, the services they needed to maintain an independent lifestyle (i.e., attendant care, transportation, etc.) would no longer be available. ${ }^{9}$ The Berkeley Centre had been organized co-operatively and, because persons with disabilities were 
involved in the administration of services, it fundamentally altered existing service delivery systems which some observers suggest represents a "paradigm shift" in service delivery systems (DeJong, 1979). Briefly, the early beginnings of the IL movement in the U.S. represented a sense of 'rugged individualism'. As Gareth Williams observes, "[t]he core constituency of the independent living movement is young, male and 'fit'" (1983: 1005). By 1977, there were some 25 Centres for Independent Living (CILs) established in the United States.

In Canada, the consumer disability movement developed in the late1960s and eariy-1970s. By the early-1980s, however, an Independent Living movement had been imported by key actors in the consumer disability movement, in particular Henry Enns, and by its national association, the Coalition of Provincial Organizations of the Handicapped (COPOH). Currently the Canadian IL movement involves 22 local Independent Living Resource Centres (ILRCs) which act as community-based disability response Centres. The movement is guided by a 'philosophy' which emphasizes the right of PWDs as citizens to have access to resources ensuring that they have the ability to "examine options, to make choices, to assume responsibility to take risks, and finally, to have the right to make mistakes" (CAILC, 1994a). In short, the primary goals of $\mathrm{IL}$ are to ensure access to resources to facilitate the full participation of persons with disabilities in society (CAILC, 1994a). To that end, IL is concerned with the independence (i.e., control and selfdetermination) and integration (i.e., full access to community resources) of persons with disabilities into our communities. The movement represents a new attitude, a new set of organizing principles, and a new approach to service delivery, which aims to ensure access of persons with disabilities to housing, health care, transportation, employment, education, and mobility. 
These aims are achieved through self-help and peer support, research and development, and referral and advocacy (CAILC, 1989b; DeLoach et. al., 1983).

\section{III}

\section{Overail Approach of the Investigation}

I came to be interested in the Canadian Independent Living movement and more generally, the Canadian disability rights movement largely through the classroom, rather than from personal experience. I first came into contact with the IL movement as an undergraduate student while researching for a term paper. My consciousness about disablement, 10 however, arose from personal experience. In May of 1991, my father was diagnosed with Amyotrophic Lateral Sclerosis (ALS). He died five months later. During the course of his illness he became a wheelchair-user and required the support of an array of community-based, disability-related support systems, not to mention the continued support of my mother. While I was not living at home during this period, I soon realized that issues relating to disablement, went far beyond simply issues of architectural accessibility. I think too many of us think that the 'disability problem' is solved if you build a ramp. In other words, if you build it, they will come.

Disablement is a highly complex and contradictory process which affects people quite differently depending on a number of interrelated elements: age, sex, race, class, sexual orientation, and geographic location, including climate. In the months proceeding my father's death, I found that I was challenging myself to confront and unravel these complexities and contradictions. I needed to understand this highly variegated and multifaceted territory. While I do not think I am much closer to answering the 'big' questions about disablement in our society, I have gained insight into 
how the process of disablement is constructed. This thesis is concerned with this process and the ways PWDs, through the disabled persons' movement challenge the passive, 'sick', and apolitical role to which society assigns them. Although I have described the reasoning behind my interest in the disability movement, I have not explicitly positioned myself within this body of work.

In 1993, I was involved in an eight month practicum placement at the Canadian Association of Independent Living Centres (CAILC); the Canadian $\Pi \mathrm{L}$ movement's federal representative body. I chose to undertake a practicum as a complement to course work because my research interests were not adequately reflected in the course offerings at Carleton. The disability field is poorly researched and undervalued throughout Canadian society and Carleton has not developed significant course offerings on the topic. ${ }^{11} \mathrm{At}$ CAILC, I was responsible for researching and writing a document detailing the history of the organization which was published in 1994.12

Subsequent to my practicum placement with CAILC, I was hired to carry out research related tasks and policy/project development. In total, I worked at CAILC for three years. Through this experience, I had the opprortunity to meet many of Canada's first disability activists involved in both the disability consumer and Independent Living movements; many of whom have become friends. As well, I was able to visit a number of the ILRCs located across the country to see for myself how these Centres respond to the needs of persons with disabilities at the community-level.

During the course of this investigation, I had to define myself as an 'other', because university researchers, for the most part, are considered 'others' within the disability rights movement. In fact, PWDs have good reason to be suspicious of university researchers. Medical professionals and social scientists often define PWDs simply as 'objects' of their research, rather 
than individuals who have agency over their everyday lives. For this reason I support the position of the disability community concerning traditional research practices and have endeavoured, in this study, not to replicate traditional approaches. That said, I must acknowledge that my experiences involve little in common with PWDs. I am a white, able-bodied, university educated, middle-class, young male conducting research about people who, as a group, are politically, culturally and economically oppressed in Canadian society.

Nevertheless, with Iris Young (1990), I believe that oppression is a central category of political discourse so while oppressed groups are not oppressed to the same extent or in the same ways, "in the most general sense, all oppressed people suffer some inhibition of their ability to develop and exercise their capacities and express their needs, thoughts, and feelings" (1990: 40). In other words, understanding and empathy for oppression can cross boundaries of race, class, gender, ability, and sexual orientation so that links between and among 'oppressed groups' can be formed. As a gay man living in a heterosexist society I understand some aspects of the nature of oppression and marginalization. While persons with disabilities and gays and lesbians experience oppression differentiy, these groups of individuals nonetheless commonly "suffer some inhibition" in their daily lives.

The transfer of empathy and understanding among oppressed groups is an important element affecting the agenda setting for this research. The late Margaret Benston, in discussing feminist epistemology and the women's movement, has provided a useful model governing agenda setting for research on the lived experienced of oppressed individuals. She distinguished among three kinds of research: (1) research on people, in which the 'experts' determine what is important and the researched community is 
treated as an object; (2) research with people, in which the power relationship between the 'experts' and the researched community remains intact, but it is defined by a process which ensures that co-speration occurs and feedback concerning the research agenda is received; and (3) research by the people in which people gain self-knowledge on question they define themselves and the 'expert' carries out the role of facilitator, co-ordinator and, if necessary, compiler of results (Benston in Vickers, 1989: 20-1). Using Benston's model, this study falls within the parameters of the second kind of research; research with people. In the next section, I expand on this point by detailing my methodological choices.

\section{IV}

\section{Methodological Approach}

Since its inception, the Independent Living movement has been actively involved in challenging traditional research practices within the academy. Indeed, IL emphasizes individual autonomy and personal control in every facet of daily life-including research. Mary Brydon-Miller, in discussing some conceptual issues surrounding methodology and Independent Living in the U.S., observes that the movement employs a "participatory-action methodology" (1993: 126). The Canadian IL movement, like the U.S. movement, adopts the participatory research (PR) model. This model is similar to Benston's third kind of research; research by people. The Centre for Independent Living in Toronto (CILT), for example, published a discussion paper on the "politics of disability research" (Woodill, 1992: 1), entitled Independent Living \& Participation in Research (1992) which sets out a research agenda that fully embraces the participatory research model. CAILC published a research guidebook entitled, Choice, Flexibility and 
Control in Community Research (1994b) in which the federal organization clearly endorses a community-based, participatory research model. The fact that the movement I am studying takes a stand on epistemological issues meant that I had to pay particular attention to my research approach and nethodological choices.

Briefly, the participatory research model is a relatively new and potentially radical approach to research which is gaining somic popularity in the social sciences. Patricia Maguire (1987) argues that it constitutes more than a new set of techniques since it also involves a new way of conceptualizing the relationship between the researcher and the researched community. In short, it is designed to develop critical consciousness to improve the lives of oppressed individuals. Advocates of PR argue that the model is not paternaiistic. Instead, they conceptualize research as a three part process of social investigation, education and action which can result, they argue, in individuals who fully participate in their daily lives (Maguire, 1987; Park, 1993). In short, PR aims to initiate a collective research process to end oppression.

Although this approach has validity and has been used by researchers doing work at the doctoral level on Independent Living, ${ }^{13}$ I concluded that it coild not be the method for my investigation because I am not a person with a disability and hence cannot do "self-studies" on this subject. In addition, I concluded PR runs the risk of individualizing the issues under study by centering concern on a particular set of events, concerning a particular group of individuals, in a particular place, at a specific point in time. Useful though these smaller pieces of participatory research are for changing a particular context, they nonetheless produce no real sense of history and precluded a comparative analysis of Independent Living in different jurisdictions. Since 
my initial goal was to understand what happened to IL when it transplanted to Canada from the U.S., comparison was essential.

I aiso had concerns relating to the political and structural limitations of the university. If I had implemented a strict PR model for this investigation, my role would have been as a facilitator. But in the university, as a degree candidate, I am responsible for the production of this work and, therefore, I concluded I had to hold primary 'control' over the research project. Given that I must control the research, the research participants cannot; hence, this study could not operate within a PR framework. Thomas Heaney, in a collection of papers discussing PR in Canada and the U.S., asserts that "participatory research can be discussed, analyzed, studied, criticized, attacked, and even lauded within the university, but its practice cannot be genuinely legitimized there" (1993: 45). The use of participatory research in the university, Heaney continues, "is simply a contradiction of that system" (1993: 46).

Nonetheless, since the inception of this study I have maintained that the production of knowledge is an integral part of the empowerment process and if oppressed individuals (in this case PWDs) are not included in the research process then they have no role in affecting their own social, political and economic reality. To that end, I have endeavoured, in this study, to give status to the self-knowledge of PWDs. I do not believe that the process of researching and writing this thesis has made me the 'expert' on disability movements in Canada. Instead, this investigation highlights the selfknowledge of people with disabilities and challenges the idea that PWDs are passive, 'sick', and apolitical. As this study shows, disability movements are important actors in Canadian political discourse. 


\section{$\mathbf{V}$ \\ Chapter Outlines}

The first chapter is largely theoretical in scope. Attempts to theorize disablement are rare; consequently I have constructed a conceptual frameworks using material from political science, sociology, law, rehabilitation science, cultural studies and geography. My aim in this chapter is to detail how PWDs have been constructed as non-people and as noncitizens in Western democracies, and how disabled persons' movements challenged these normative understandings. I explore the meaning and material experience(s) of disablement and the way in which concepts of citizenship intersect with identity politics.

In chapter two, my discussion turns to the history, structure and crossnational diffusion of the Independent Living movement from the United States to Canada. I focus on the evolution of disability organizing in Canada by tracking first 'professional' organizations, and later the emergence of the provincial and federal consumer disability rights and Independent Living movements. In the second section, I compare Independent Living in the U.S. and Canada to uncover how Canadian disability movements re-defined and pursued their representation project (Rankin, 1995) through both institutions of the state and civil society. I account for the differences between the U.S. and Canadian IL movements through a discussion of the political opportunity structures (POS) in each country and the varying character of the welfare states in which the movements find themselves located.

Finally, in chapter three I explore the relationship between the Canadian federal state and disability movements. I begin by providing an overview of Canadian movement literature focusing on how this literature assists in explaining disability organizing. I focus on the importance of 
Canada's vast territory, northern climate and sparse population, as well as the importance of federalism for Canadian disability movements. Next, I consider the context in which disability movements emerged, using the analytic concept of POS by accounting for the favourable response of the federal government towards disability movements in the late-1970s and 1980s. Next, I detail the response of the federal government to the goals of Canadian disability movements through an examination of federal disability initiatives since 1980. Finally, in the last section of the chapter, I present a case study of the extension of federal support to the Canadian Independent Living movement. Through an examination of a central wing of the Canadian disability movement, I will show how the federal government directly contributed to the development of the movement. In fact, I will show that Canadian disability movements could not have emerged as panCanadian movements without the support of the federal state during the 1970s and 1980s. 
NOTES

${ }^{1}$ The identity formation processes of movements have been theorized by European scholars. See, for example, Alberto Melucci, Nomads of the Present: Social Movements and Individual Needs in Contemporary Society (London: Hutchinson Radius, 1989); Carol Boggs, Social Movements and Political Power, (Philadelphia: Temple University Press, 1986); R. Eyerman and A. Jamison, Social Movements: A Cognitive Approach (Cambridge: Polity Press, 1991).

2For treatments by U.S. scholars of the resource mobilization approach, see, Charles Tilly, As Sociology Meets History, (New York: Academic Press, 1981); and M. Zald and J.D. McCarthy (eds), The Dynamics of Social Movements, (Cambridge, Mass.: Winthrop Publishing, inc., 1979). More recently, attempts have been made to synthesize these approaches, see, for exampie, Aidon D. Morris \& Carol McClurg Meuller (eds), Frontiers in Social Movement Theory (New Haven, Conn.: Yale University Press, 1992); and Bert Klandermans and Sidney Tarrow, "Mobilization into Social Movements: Synthesizing European and American Approaches," International Social Movement Research 1 (1988): 1-38.

3 For Canadian treatments of movement theory, see, William Carroll (ed), Organizing Dissent: Contemporary Social Movement in Theory and Practice (Toronto: Garamond, 1992); and Susan Phillips, "New Social Movements in Canadian Politics: On Fighting and Starting Fires," James P. Bickerton and Alain-G. Gagnon (eds), Canadian Politics 2nd ed, (Peterborough: Broadview Press, 1994).

${ }^{4}$ Canadian disability organizing has also been dealt with in Evelyn Kallen, Label Me Human: Minority Rights and Stigmatized Canadians, (Toronto: University of Toronto Press, 1989); and jerome Bickenbach, Physical Disability and Social Policy, (Toronto: University of Toronto Press, 1993).

5The 'newness' of movement activity has been a much-debated theoretical territory within movement theory. The debates centre around questions of membership, ideology and the relationship movements have with traditional forms of political activity. My understanding of the 'newness' of movements has been influenced by Canadian political scientist, Lorna Weir, in which she argues that contemporary movement theory has been guilty of ahistorical approaches to understanding movement activity. See, Lorna Weir, "Limitations of New Social Movement Analysis," Studies in Political Economy 40 (Spring, 1993): 73-102.

GThe available research on the early development of the Canadian consumer disability movement is scarce. Nevertheless, I am indebted to Diane Driedger for providing me with a copy of an unpublished manuscript she researched and wrote detailing the eariy history of the movement. As well, Diane consistently supported my work and shared her knowledge about disability organizing in Canada. Without her research and personal comments, this study would have been incomplete.

${ }^{7}$ It is important to note that the central reason for this is simply because PWDs have been largely excluded from participating in the labour market. In 1986,60\% of Canadians with disabilities who were working age were unemployed (Canada. Statistics Canada, 1988).

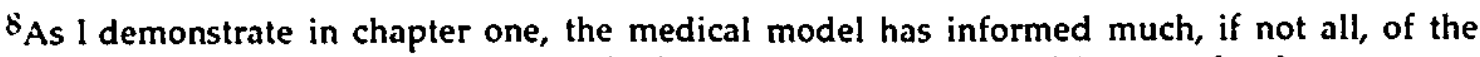
medical research and practices since the late-nineteenth century. Many myths about persons with disabilities can be attributed to the theories 'experts' (particularly medical experts) 
have developed. Historically, medicine has constructed an image of a person with a disability as compliant, inadequate and inept. This has placed undue emphasis on clinical diagnosis in the medical model. As a result, this understanding of disability has led to a partial and inhibited view of persons with disabilities. At a broader level, the medical model affects all persons who engage with the medical profession simply because the patient/doctor relationship has been founded on the 'validity' of the medical model.

${ }^{9}$ The first evidence of persons with disabilities living in a 'community-based' environment seems to point to the University of Illinois, when in 1962, four "severely disabled students" were "transferred from a campus-isolated nursing home to a modified home closer to campus" (Dejong, 1979: 437). The Berkeley Centre, however, is the first example of persons with disabilities organizing on their own behalf to manage the services that affected their daily lives.

10 My use of the term 'disablement' has been influenced by the work of Jerome Bickenbach. Bickenbach recognizes the importance of language in scholariy work and the debate which has persisted concerning the use of certain terms over others. Not discounting this debale, he concludes that the "disablement' is both an artificial and "reiatively neutral" term which can be used to denote an array of terminology including: 'impairment,' 'deficiency, 'medical problem,' 'dysfunctioning,' 'physical disability,' 'physical inability,' 'physical incapacily,' 'handicap,' and so on. See Bickenbach, (1993): 20-23.

${ }^{11}$ Currently, to my knowledge, there are two courses (one in Social Work and one in Law) on disability and related issues at Carleton.

12 See, Fraser Valentine, The Canadian Independent Living Movement: An Historical Overview (Ottawa: CAILC, 1994).

${ }^{13}$ For a discussion on the methodological issues arising from the implementation of a participatory research model on the Independent Living movement, see, Mary Brydon-Miller, "Breaking Down Barriers: Accessibility Self-Advocacy in the Disabled Community." In Voices of Change: Participatory Research in the United States and Canada. Peter Park, Mary BrydonMiller, Budd Hall and Ted Jackson (eds), (Toronto: OISE Press, 1993). 


\section{CHAPTER ONE}

\section{DISABILITY MOVEMENTS IN CANADA: \\ Identity, Citizenship and the Challenge of Disability}

\section{Introduction}

Scholars with disabilities have called for the creation of a new knowledge which moves beyond simply offering "descriptive and atheoretical accounts" of disability towards research which "take[s] both the issue of disability and the experiences of disabled people seriously in their own right rather than as marginal to both theoretical developments and empirical work" (Oliver, 1990: $\mathrm{x}$ ). There is evidence that this call slowly may be addressed. Emerging social science research which includes the selfknowledge of PWDs and their organizations is emerging in sociology (Scotch, 1984; Oliver, 1990; Morris, 1991; Gadacz, 1994), anthropology (Kallen, 1989); history (Driedger, 1989); law (Bickenbach, 1993); and cultural studies (Davis, 1995). Nonetheless, there is still little theoretical work about PWDs and their organizations as autonomous political actors. Political science has been little influenced by ideas about disablement and largely has ignored empirical and policy work on disabled persons' movements. Disablement is treated, if at all, as an 'add-on' to existing theoretical models accounting for movement activity in Canada, the United States and Britain. ${ }^{1}$ My goal in this chapter is twofold: (1) to highlight the fact that there is little material examining the theoretical nexus of PWDs as autonomous political actors able to advocate on their own behalf; and (2) to examine how PWDs and their organizations fundamentally have challenged traditional understanding of citizenship and identity politics. 
I begin by exploring the 'meaning of disablement', examining the construction of disability in western societies both as a concept and as a category. My focus is on the construction of the major factors which have influenced the normative understanding of disablement in western society. Next, I consider how these normative understandings of disablement have affected the 'personhood' of PWDs. My understanding of the concept of 'personhood' has been influenced by the work of Benedicte Ingstad and Susan Reynolds Whyte, two Scandinavian scholars who provide us with an anthropological investigation of disability from an international perspective. They argue: "If personhood is seen as being not simply human but human in a way that is valued and meaningful, then individuals can be persons to $a$ greater or lesser extent" (my emphasis, 1995: 11).2 In this section, I argue that the understanding of PWDs as inadequate and 'sick' resulted in their construction as 'non-people' and therefore, directly contributed to society's normative understanding of PWDs as non-citizens. I move to consider, generally, how states have dealt with PWDs over time focusing especially on the way in which the contemporary welfare state has elaborated the 'meaning of disablement' through administrative and legislative criteria. Finally, I conclude the chapter, by detailing how disability movements since the $1970 \mathrm{~s}$ have rejected the normative understandings of disablement and begun the process of reinterpretation and self-definition to include a consideration of how disablement intersects with factors such as race, class, sex/gender, sexual orientation and geographic location/climate. 


\section{I \\ People with Disabilities and Identity Politics}

Jane Jenson argues that "a full understanding of politics depends upon attention to and analysis of the politics of identity" (1994: 54). While I agree with Jenson that "Ip]olitics is always identity politics, even when they appear to be about other things" (1994: 55), politics is also about material wants and needs. In fact, for no other group is this more true than PWDs. "Our preferences, our actions, and even our expectations about what is political," Jenson continues, "are related to the notions we share about the collectivities to which we belong, about our identities as citizens, about what Canada is, about who our fellow citizens are, and about why they have rights" (1994: 55). For PWDs and their movements, however, the social science disciplines have largely ignored their position as political actors with citizenship rights expressing their material needs, wants and their identities. This is partly because most Canadians still do not yet fully understand the identities of PWDs as members of a collectivity and as citizens with individuals rights and entitlements to their material needs.

Disablement is little studied within the social sciences. In Canada, the United States and Britain neither the issue of disability nor the experience(s) of PWDs and their movements have been of central theoretical, policy, or empirical importance within academic knowledge systems. Although these issues have been given some prominence within medicine, social work, psychology and to a lesser extent within sociology, scholars who themselves have disabilities (Oliver, 1990) have argued that this work has been counterproductive because it resulted "in the issue of disability being seen as essentially a medical one and the experience of disability being contingent upon a variety of psychological adjustment processes" (Oliver, 1990: $\mathrm{x}$ ). This 
approach meant that within western societies the issue and experience(s) of disability and disablement have been individualized and medicalized, perpetuating the notion that disability stems from functional limitation involving personal misfortune and/or biological inferiority (Oliver, 1990); Bickenbach, 1993; Hahn 1989).

If the processes of politics can only be fully understood, as Jenson asserts, "when a political actors' own ideas about and definitions of themselves [sic] are given full consideration by political scientists" (1994: 54) then we know very little about the PWDs and their organizations as autonomous political actors within Canadian society. To understand the processes behind our flawed understanding of PWDs and their movements, I will consider the dominant models which have constructed disablement as both a normative concept and category.

\section{II \\ The Meaning of Disablement: The Role of Modern Medicine and Social Science Research}

What is disability? This relatively simple and obvious question has a highly complex and multi-faceted answer. As René Gadacz asserts “[d]isability can mean many things" (1994: 4). The rise of disabled persons' movements in the United States and Canada pushed PWDs, researchers, policy makers and medical professionals to view disability increasingly as a socially created category, a product of a series of complex political, economic and social relationships (Bickenbach, 1993). While I would not suggest that this 'push from the grassroots' has shifted official discourse about disability significantly, our understanding of disablement has broadened in recent years because of the self-assertion of movements of PWDs. Disablement remains constructed as a formal administrative category, a legal category, a multi-million dollar 
business activity, a research area and a set of medical conditions, but there is a growing awareness that disablement means much more.

As I discuss later in this chapter, three conceptually independent dimensions of disablement have recently emerged-impairment, disability and handicap ${ }^{3}$ - which are shown schematically in Figure 1 (WHO, 1980).

\section{FIGURE 1}

\section{Dimensions of Disablement}

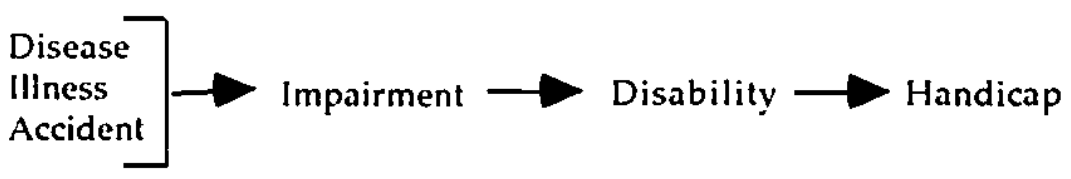

Source: Gadacz, (1994): 35

The linear nature of this schematic is deceiving. Disablement is not and should not be understood as a three step process-you are impaired, you have a disability, and you experience handicapping. Nonetheless, it does show that there is a growing awareness that disablement involves: (1) a conceptual concept; (2) a social process; and (3) a category of identification.

Movements of PWDs who organized on their own behalf have pushed researchers and medical professionals to understand that disability is neither wholly an 'attribute' of an individual nor an objective 'fact'. Instead, it is a socially created web of relationships, influences and forces. Sandra Carpenter, a disability researcher and activist, has referred to the multi-faceted nature of disablement as the "undefinable nature of the disability collective" involving "a slippery hodgepodge of conditions, diseases, genetic disorders and malformations" which are "all validated...by disabled individuals themselves, the cultures they come from and the times they live in" (1991: 25). PWDs are not a monolithic group. Instead, they are heterogeneous in 
terms of race, class, sex/gender, language, ethnicity, sexual orientation and geographic location/climate.

Perhaps more than any other group, PWDs have faced scholarly forces which constructed them as 'ugly'. Iris Marion Young argues that "[n]ineteenth and early twentieth century scientific, aesthetic and moral culture explicitly constructed some groups as ugly or [having] degenerate bodies, in contrast to the purity and respectability of neutral, rational subjects [the while bourgeois man]" (1990: 125). Much of the so-called disability research contributes to this assessment as researchers from numerous disciplines in the medical and social science fields tried to 'get to the bottom' of the disability 'problem' over the past 80 years. It is my contention that modern medicine and social science research have all contributed to the construction of PWDs as 'deviant' and passive and thus, apolitical beings or non-citizens in the contemporary welfare state. This literature imposed an identity (Anspach, 1979) on PWDs as passive and powerless, as well as 'ugly' and 'deviant'. The emergence of self-advocacy movements of PWDs, however, represents a powerful force to reconstitute and redefine PWD's "spoiled identities" (Gadacz, 1994: 9).

Bio-medical research (including medical and rehabilitation literature) has had a fundamental influence in the lives of PWDs. Biological determinism and scientific positivism have dominated North American thinking about disability throughout this century. Marcia Rioux argues that science and medicine were used as "political legitimation for differentiation and unequal treatment" of PWDs for most of this century (1994: 70). The North American eugenics movement used biological determinism to 'explain' differences and 'justify' such things as involuntary sterilization (Rioux, 1994; McLaren, 1990). PWDs, particularly those with cognitive 
disabilities suffered institutionalization and involuntary sterilization as a result of eugenics theories. ${ }^{4}$ Lise Noël, in her book Intolerance in which she undertakes a comparative interdisciplinary investigation of all relationships of domination and the parameters of identity in modern western societies, observes:

[S]cientific experts...sanctioned the principle that the authorities [had] the right to treat the bodies of the mentally handicapped without their consent by allowing them to be subjected to sterilization (1994: 57).

Positivism, functionalism and biological determinism have been the driving paradigms for the development of the medical model of disablement used by disciplines including medicine, rehabilitation, psychology and sociology. 5 Jerome Bickenbach characterizes the medical model as one which "holds that for a condition to qualify, medically speaking, as a disease, it must have a clinically ascertainable causal history that explains the mechanisms by which changes in the structure or functioning of the body are manifested in specific ways" (1993: 25). Within the biomedical model, therefore, a link is made between disease and medicine. Individuals are understood as 'sick' and having a medical 'defect' or 'problem' which can be 'cured' with the aid of medical science or alternatively, they are declared 'incurable' (as often occurred in the nineteenth century). ${ }^{6}$ In the twentieth century, however, the medical model has resulted in the definition of many impairments by socalled 'experts' and the adoption of agendas for action including programs of prevention, cure, pain control and rehabilitation (Bickenbach, 1993: 61-92).

McColl, Gerein and Valentine (forthcoming) have characterized a number of assumptions which underlie the medical model. First, the model assumes that the disabled individual has a "normative deviation in everyday functioning" which can be "objectively detected" through biomedical 
assessments (forthcoming). Next, the model has an inhibited view of PWDs because it assumes that individuals themselves are "ill-equipped to make decisions" (forthcoming) and it is the professionals who have the "information and skills" to make the required decisions. Third, the model assumes individuals can be reduced to a series of "subproblems associated with different body systems" (forthcoming). Consequently, PWDs are understood to be incomplete individuals. Finally, the medical model assumes that individuals must alwavs cooperate with medical intervention because it assumes PWDs have a responsibility "to pursue optimal functioning" and "to cooperate with service providers" (forthcoming). This approach is fueled by an understanding that no matter the 'cost' or individual 'pain' involved, medical intervention must get the individual back to 'normal'. As I detail later in this chapter, PWDs and their movements emerged largely to reject the assumptions contained in the medical model.

Michael Oliver's characterization of the medical model is similar to McColl et. al. He concludes the model "produces definitions of disability which are partial and limited and which fail to take into account wider aspects [economic, social, cultural, political] of disability" (1990: 5). Oliver identifies three further problems with the theoretical underpinning of most disability research: (1) that most research "ultimately reduce[s] the problems that disabled people face to their own inadequacies or function limitations"; (2) that the research "has failed to improve the quaiity of life for [PWDs], while doing no harm to the career prospects of the researchers"; and (3) that "the theoretical underpinnings of much research on disability have been so divorced from everyday experiences of disabled people that they have felt victimised [sic] by professionals..." (in Woodill, 1992: 7). 
René Gadacz suggests that, while the medical model may be a necessary mechanism for controlling the flow of patients and clients in and out of human service programs and services, it should not provide medical professionals with the power or right to control those aspects of an individual's life which are beyond medicalization-in particular, social, sexual, political and economic conditions (1994: 53-4). As ? discuss in chapter two, prior to the emergence of disability movements, the problems of, for example, dependency, low income, social isolation, and architectural inaccessibility were rarely discussed.

Evelyn Kallen (1989) observes that the medical model "heavily influenced" social science theories about disablement, especially in sociology. Most influential, have been U.S. theories about deviance and labeling. First developed by Beatrice A. Wright (1960), Erving Goffman (1961; 1963) and Constantina Safilios-Rothschild (1970), deviance theory was used to develop "an etiological explanation for deviant behaviour"7 which, like the medical model "focused on the [liability of the] individual," rather than, for example, the surrounding environment (Kallen, 1989: 26-7). Deviance, then, is a social label equally applied to individuals and groups, who are labeled by the majority because of an attribute which is real or perceived. As Bickenbach suggests, these individuals and/or groups, are viewed as "rule-breaking" or "norm-violating" (1993: 142) and are therefore considered in a hierarchically lower social-status position."

Goffman's application of deviance theory in his still influential essay Stigma (1963), was an initial attempt to characterize PWDs, not as deviants because of "voluntary" behaviour (which he considered criminals, drug users, and prostitutes to be), but instead as "involuntary deviants". Nonetheless, Goffman argued that, by definition, individuals with a stigma 
such as an impairment were considered "not quite human" (Goffman in Hahn, 1989: 374). Others followed Goffman by reasoning that the social stigma of disablement was pronounced. Bickenbach concludes that, "disablement is a socially created category applied to people with disabilities by 'normals' in order to discredit them indirectly by justifying prejudice, stereotyping, and misperceptions" (1993: 143). ${ }^{9}$ Indeed, the emergence of labeling theory or the labeling paradigm was in part derived from the deviance approach.

The labeling paradigm is a popular off-shoot of deviance theory which "stresses the importance of social categorization in the creation of forms of interaction and self-perception" (Bickenbach, 1993: 143). In other words, the process of labeling constructs an identity imposed by the majority on a minority individual or group. As Bickenbach notes, Howard Becker (1963), an early labeling theorist, argued that "the deviant is one to whom that label has successfully been applied; deviant behavior is behavior people so label" (1993: 144). Labeling therefore is seen as an important social process in which some individuals are characterized as 'abnormal' and therefore 'deviant'.

While this body of work has been useful and influential beyond the disciplinary boundaries of sociology, it has been criticized for methodological and theoretical problems (Farrell and Swigert, 1988). In particular, the theory is criticized because it is ill-defined and "far too mysterious...to have any explanatory power" (Bickenbach, 1993: 144). The theory stresses social processes but continues to conceptualize the 'problems' of impairment and stigma "as some sort of personal deviation" (Anspach, 1979: 767). The focus of deviance theory tends to be on the social, especially on individual pathology, structural-functional elements and therapeutic methodologies, 
rather than on the political (Horowitz and Liebowitz, 1968). Evelyn Kallen argues that,

[The] theoretical models that have conceptualized stigmatizedminority status as a function of 'deviancy' almost invariably have had the unintended consequence of reinforcing prevailing prejudices and stereotypes underlying minority stigmata (1989: xi).

Kallen is a bridge-builder between what initially appear as two disparate bodies of literature-medical and social science. She argues that neither sociological nor biomedical theories can ever be "value-free" and "purely scientific."10 Operating out of what she calls a 'minority-rights analysis', Kallen suggests that the central theoretical tools used by social scientists have been "flawed with an abiding tendency...to "blame the victim"" (1989: xi).

Lise Noël suggests that the social and human sciences have contributed to the discourse of otherness because it is these disciplines which "convey...knowledge" that is "established by the dominator" (1994: 24). The othering process through academic discourse proceeds in the following manner:

In proposing the dominator as the perfect embodiment of humanity tailored, from the outset, to his own measure, the various disciplines endorse the intrinsic inferiority of the oppressed, implicitly justifying the latter's dependent condition. Because he is the original model, the dominator is rarely depicted in his specificity. It is the "other" who is the "object" of observation, and who, because of his or her difference, constitutes the "problem" or "subculture" that the various disciplines endeavour to analyse. (1994: 24).

For PWDs this situation is pronounced because, according to Noël "[i]ntolerance is always fuelled by physical difference, which it views as signs of intrinsic otherness" (1994: 110). Those individuals with cognitive disabilities often experienced a harsher process of othering. Noël maintains that "...mental illness....was defined as 'abnormal behaviour' meaning that it 
was behaviour different from that of the majority...[and therefore was] labeled 'exotic' or 'culturally linked'" (1994: 29). While intolerance was "[i]nitially conceived as the rejection of a belief or attitude," the process of othering means that intolerance is "now applied to the rejection of a way of being" (1994: 5).

It becomes clear that constructing some individuals and/or groups as 'othered' necessarily creates a category of individuals who are so-called 'normal'. In effect, normalcy involves the assumption that PWDs are 'damaged' and therefore non-people or incomplete people, while the observer, and others in wider society are 'undamaged' or 'normal' people. Lennard Davis, in his book, Enforcing Normalcy tracks the cultural assumptions governing the conceptualization of PWDs in western societies, arguing that the concept of disability is "a socially ariven relation to the body" which became formalized in the eighteenth and nineteenth centuries (1995: 3). Davis is a British cultural theorist so it is important to note that his analysis may not fully capture all of the Canadian reality for PWDs because, as I argue throughout this study, the environment in which individuals live also affects their experience(s) of disablement. Nevertheless, I agree with Davis that the meaning of disability is constructed through the set of social, historical, economic, political and cultural processes which "regulate and control the way we think about and think though the body" (1995: 2). He posits that "the 'problem' is not the persons with disabilities; the problem is the way that normalcy is constructed [which in turn] create[s] the 'problem' of the disabled person" (1995: 24). In short, the notion of normalcy, Davis concludes, "makes the idea of disability possible" (1995: 158). In the next section, I examine how the constructed understanding of PWDs as 'damaged', 
'incomplete', or non-people through medical and social science research has diminished their opportunities for meaningful citizenship.

\section{III}

\section{People with Disabilities and the Politics of Citizenship}

People with disabilities have suffered severe exclusion from the public realm of political, economic and social activity. The theoretical literature of the contemporary liberal-democratic states "continues to present the political as something abstracted from, as autonomous or separate from, the social relationship of everyday life" (Pateman, 1989: 92). Carole Pateman has characterized the public individual as "the universal citizen" who is "disembodied," "dispassionate (male) reason," "white," and "bourgeois" (Pateman, 1988; 1989). A universal citizen, then, is created through the construction of a constituted public realm based on an exclusionary understanding of citizenship. As Iris Marion Young suggests:

The modern conception of the public...creates a conception of citizenship which excludes from public attention most particular aspects of persons. Public life is supposed to be 'blind' to sex, race, age and so on, and ail persons are supposed to enter the public and its discussion on identical terms. This conception of the public resulted in the exclusion of persons and aspects of persons from public life (1990: 120).

The civic public then has been defined by the 'virtues' of impartiality and universality which has resulted in the exclusion of human particularily-including physical and mental difference-from this realm. Young has characterized the existence of human particularities with "women, homosexuals, Blacks, Indians, Jews and Orientals" (1990: 110-11). As I detailed above, PWDs have been configured as an 'othered group' and therefore excluded from participation in the civic public as citizens. René Gadacz 
asserts, for instance, that "the disabled [sic]...have been relegated to the position of second-class citizenship" (1994: 255). As I discuss below, people with psychiatric disabilities did not get the legal citizenship right to the federal franchise until 1991. This literature, however, does not theorize how and why PWDs are constructed as non-citizens and therefore denied their presence as political actors.

The British sociologist, T.H. Marshall's famous essay, "Citizenship and Social Class" (1963), on the relationship between class, citizenship and democracy in Britain is a good starting point for the current analysis." Marshall argues that "[c]itizenship is a status bestowed on those who are full members of a community" and all individuals "who possess the status are equal with respect to the rights and duties with which the status is endowed" (Marshall and Bottomore, 1992: 18). The elements of rights and duties are central to the original concept of citizenship because, as Marshall argues, an individual can only claim a "certain standard of civilization" upon "the discharge of the general duties of citizenship" (Marshall and Bottomore, 1992: 26). Prior to discussing the concept of duties in detail, I want to outline Marshall's three elements of citizenship-civil, political and social rights-to concretely show how full citizenship has been and continues to be denied to PWDs in western societies.

Civil rights (for men), the first of Marshall's three elements, developed in the eighteenth century and is comprised of those elements which guarantee individual men: freedom; the right to free speech and faith, the ability to own property and conclude contracts and the right of law. Political rights were fully developed for men who were not disabled in the nineteenth century and extended the ability to participate in the political process as an elector and/or voter. ${ }^{12}$ Finally, the idea of social rights developed in the 
twentieth century and are comprised of a range of elements guaranteeing economic welfare, social participation and personal security. The institutions in civil society most closely aligned with social rights are the educational system and social services (Marshall and Bottomore, 1992: 8-10).

Marshall was concerned with the substantive, rather than simply the formal rights of citizenship, but like many social scientists of his period, Marshall's notion and timing of rights is biased in two fundamental ways: it is Euro-centric and male-centered. Marshall overlooked elements such as gender, race and most important for this study, physical and mental ability. He argues that the 18th century was the century for the development of civil rights, the 19th brought political rights and the 20th century, social rights. It is clear that the historical development citizenship through Marshall's three elements, although valid for most men, developed at a much different pace for women, First Nations and visible minority peoples, and PWDs.

Rian Voet (1994) critiques both Marshall's conceptualization of citizenship and feminist debates surrounding citizenship rights. Using Marshall's citizenship model, she concludes that "women do not have the rights men have" and suggests further that a full understanding of citizenship is only possible when "both rights and political participation...are incorporated" into citizenship definitions (Voet, 1994: 61-2). Voet's contribution is valuable because it highlights the fact that women got the vote (political rights) prior to securing full civil rights. The same is true of people with disabilities.

Full political rights for PWDs in Canada came not in the nineteenth century, but in 1991, when individuals with mental disabilities were finally enfranchised. The fundamental right of the franchise was extended only after the Canada Elections Act was amended to allow persons with a psychiatric or 
mental disability to vote in federal elections. The legislation was changed only after the Canadian Disability Rights Council (CDRC), a national legal think-tank on disability issues and the law, challenged the legislation in the courts on behalf of PWDs and won. For people with physical disabilities, full access to the franchise was guaranteed only in 1992 when the architectural accessibility of polling stations became mandatory. ${ }^{13}$ As well, voting materials must now be made available in alternate media (large print) enabling people with a variety of disabilities (i.e., blind individuals) the opportunity to vote. Prior to this point, polling stations were chosen with total disregard to the accessibility of disabled voters. As well, there are now a few PWDs serving as legislators in Canadian legislative assemblies, including the House of Commons and accommodation to their needs is being learned by these central political bodies. It is important to stress, however, that despite these advancements PWDs still face barriers to their full participation in the political system. Michael Oliver argues, for example, that PWDs and their organizations cannot effectively participate in the political process of third party lobbying either from the pluralist, corporatist or minority group positions (1990: 106-7).

As I mentioned above, Marshall's typology of citizenship also includes the notion of duties. Originally conceived, citizenship duties meant the ability to bear arms to protect the collectivity. Later, with the development of the contemporary welfare state, citizenship duties shifted to the ability to engage in the capitalist system of paid employment. This argument has most recently been advanced by Carole Pateman (1989). Following Canadian political scientist C.B. Macpherson (1973), she maintains that under liberalism the central criterion for citizenship is independence (Pateman, 1989: 185-192) which conceptually is based on "masculine attributes and abilities (my 
emphasis, Pateman, 1989: 185). Modern political philosophy, therefore, has constructed 'the citizen' as a social and political being who is able-bodied, just as it has constructed the citizen has male.

PWDs, by virtue of their physical or mental impairment, have not been viewed as able to perform the duties necessary for full citizenship status; that is, neither the capacity to bear arms nor the ability to be self-sufficient through meaningful employment. Many adult men and some women, however, have been disabled because they were performing their "citizenship duties" in war (or at work). That said, it is important to note that men with disabilities have nonetheless benefited from state provisions for veterans disabled during war. In fact, the Second World War and the Vietnam War are the two most significant events in North America responsible for catapulting the daily lives of men with disabilities into the social policy mainstream of the contemporary welfare state (Bickenbach, 1993: Oliver, 1990; Driedger, 1989). In a relatively short period of time, policy makers had to contend with many men and fewer women who ware entitled to assistance from the state for disability-related services. ${ }^{14}$ Pateman calls this "separately administered welfare state" the "warfare state," noting it has benefited men mainly "because of their special contribution as citizens" (1989: 186). Similarly, Jerome Bickenbach points out, "[t]hat the needs of veterans were 'deserving' and could not be denied, and so we see disablement programming flourish after wars" (1993: 94). It seems, therefore, that men with disabilities caused by participation in war do not lose 'meaningful citizenship'. As with benefits for the poor, they were the "deserving poor" while other PWDs were less so.

The theoretical suppositions of the warfare state are important but Pateman insists in the "democratic welfare state" it is "employment, rather 
than military service [which] is the key to citizenship" (1989: 186). Employment is elusive for many PWDs, although prior to the industrial revolution, PWDs participated much more fully in work through which they could support themselves (Oliver, 1990: 85), Michael Oliver asserts that with the onset of mechanization and later, Fordism, "disabled people [were] excluded from the work process, because of the changes in methous of working and the new industrial discipline [which made] meaningful participation in work difficult, if not impossible" (1990: 85). Oliver continues by suggesting that in modern capitalist societies "disabled people are likely to face exclusion from the workforce because of their perceived inabilities" (1990: 86).

Lennard Davis concurs with Oliver arguing that the value of the productive capacities, especially of the male body, is clear in western society simply because "[v]alue is tied to the ability to earn money" (1995: 85). Davis asserts that, "'[a]ble-bodied workers' were those who could operate machines, and the human body came to be seen as an extension of the factory machinery" (1995: 87) which meant that "[i]f one's body is [to be seen as] productive, it is not disabled" (1995: 131). Many women with disabilities 'produced' babies, but continued to be viewed as 'unproductive'. In the latetwentieth century, our economy has moved from an industrial to a postindustrial base which permits greater participation by PWDs in the paid workforce. Nevertheless, the empirical evidence still supports the claim that PWDs are viewed as non-productive. The Health and Activity Limitation Survey (HALS), conducted by Statistics Canada in 1991, found that 4.2 million Canadians, or $16 \%$ of the population reported some level of disability. Of these, 2.3 million were working age and almost half $(44 \%)$ were unemployed. It was also determined that $17 \%$ of PWDs had never had paid work and a 
further $38 \%$ had not had paid work in the previous five years. On average, PWDs have less education that non-disabled counterparts and over $70 \%$ of the disabled population earn less than $\$ 10,000$ per annum. For First Nations peoples, racial minorities, and women with disabilities the situation is much more critical. Women with disabilities have still lower education levels and opportunities and earn significantly less money than their male counterparts. As well, women with disabilities experience a higher level of violence than non-disabled women and often find support systems such as women's shelters inaccessible (Doucette, 1991).15 First Nations peoples and racial minorities with disabilities must also deal with issues related to status, jurisdictional complexities, and in many instances, geographic and cultural isolation (Demas, 1993: NAND, 1993). ${ }^{16}$

In Canada, there is a further aspect of the construction of the citizen as able-bodied and rational. Canada is a settler society; that is, it is a country originaiiy formed out of European settler colonization imposed on a largely displaced and dispossessed First Nations populations (Berger, 1981; Frieders, 1993). Canadian sociologist Daiva Stasiulis and political scientist Radha Jhappan argue that Canada developed as a "white settler society" in which it was "the intentions of colonial administrators to build in Canada an 'overseas extension' or replica of British society" (1995: 97). While the authors correctly point out the racist and androcentric character of this construct, it has value in helping us understand that "those at the helm of the colonial, then dominion, states and those shaping civil society drew from British imperial and homegrown philosophies about the appropriate character, physical appearance, role and behaviour of settler women and men" (1995: 97). A focus on 'nation-building' meant that immigrants, in the eyes of the colonial administration, had to provide the labour and (less often) the capital to 
construct railways, extract resources, and later, work in factories (1995: 97).

Given the focus of immigration to recruiting individuals of 'hearty' stock', it precluded the inclusion of persons with physical and mental disabilities from Canada's initial citizenry. Lennard Davis argues that, "[t]he emphasis on nation and national fitness obviously lays into the metaphor of the body. If individual citizens are not fit, if they do not fit into the nation, then the national body will not be fit" (1995: 36). In contemporary Canada, little has changed. Although immigration patterns have changed, the underlying assumptions of the policy remain intact. PWDs are often disallowed Canadian citizenship because they are incorrectly thought to put an 'undue strain' on our social and economic resources. In addition, as I discussed above, the North American eugenics movement is another stark example of nation-building through the creation of a ' $\mathrm{fit}^{\prime}$ ' national body by legal sterilization. Alberta's Sexuai Sterilization Act, for instance, was repealed only in 1972; after almost 3,000 individuals (mostly women) had been legally sterilized. ${ }^{17}$

\section{IV}

The Contemporary Welfare State and the Meaning of Disablement

I have described briefly the way in which the welfare state responded to the increasing numbers of veterans (mostly men) returning from war with disabilities. Those who were disabled during the Second World War gained entitlements through the welfare state by virtue of service in the war; that is, they exercised a central duty of citizenship. Prior to the extension of the franchise to women's after the women's suffrage movement, participation in war was seen as a central duty of citizenship. The medicalization of PWDs, however, constructed them as passive, imperfect and 'sick'. People with 
cognitive disabilities were simply not considered "human enough" (Kallen, 1989) to be citizens in any context.

As the Canadian welfare state expanded during the 1950s and 1960s, the state undertook more responsibility for the care and provision of services and supports for PWDs. Shlomo Hasson and David Ley (1994), in their comparative study of neighbourhood organizations and the welfare state, clearly illustrate the federal government's 'grasp' of powers over health and social spending from local and provincial governments beginning in the mid-1940s. They note that by 1945, the Canadian federal government "was responsible for 72 per cent of health and social spending, and the municipal share was down to 7 per cent" (Hasson and Ley, 1994: 25). I maintain that the state's assumed responsibility over, in part, social spending created an image of PWDs as dependent which was used to justify the explicit denial of civil and political citizenship rights to PWDs.

The emergence of the contemporary welfare state has had profound implications for PWDs. Susan Reynolds Whyte and Benedicte Ingstad, in tracing the history of disability in western societies, argue that Euro-American assumptions about disablement are based, "not only...in a particular political philosophy, but are elaborated through a set of laws, administrative procedures, medical diagnoses, welfare specialization, and business interests" (1995: 9). The new entitlements available tinrough the welfare state, therefore, imposed a contradictory identity on PWDs-as citizens/workers and yet still 'imperfect' beings. In other words, legislative activity and administrative frameworks within the welfare state mean that PWDs have been further constructed as 'imperfect' beings who gain citizenship rights (via entitlements) through administrative frameworks such as: disablement 
definitions, disability program criteria and degrees of impairment severity scales (Whyte and Ingstad, 1995: 8).

It is in this sense that, U.S. political scientist Harlan Hahn argues that "disability is whatever [public] policy says it is" (1985: 294). In North America, PWDs are entitled to services and supports, but these entitlements do not stem mainly from assertion of citizenship rights. Instead, they are elaborated through administrative processes of the welfare state which has developed definitions of disablement and which assigns the medical profession the responsibility of cetermining who is entitled to these citizenship rights. The determination of disability entitlements is medically driven. Nonetheless, Deborah Stone (1984), in her analysis of disability as an administrative category in the U.S., reveals that disability also involves political decisions about the distribution of services and supports. Gary Albrecht (1992), for instance, shows that disability is "big business" because of the medicalization and professionalization of the rehabilitation industry which first emerged in North America after the First World War. In short, disablement has become commodified by the dissemination of goods and services through the contemporary welfare state. Only recently has it come to be seen by PWDs as contested political ground in which they assert their rights as citizens.

The commodification of disablement, first though medicalization, then the rehabilitation industry, and finally, through the welfare state resulted in the need for a clearer definition of disability so entitlements could be distributed fairly and 'cost-effectively'. In 1975, the World Health Organization (WHO) developed a new conceptual framework within which to understand disablement in the age of the contemporary welfare state. Published in 1980 by the World Health Organization (WHO), the International Classification of Impairment, Disabilities and Handicaps: A 
Manual for Classification Relating to the Consequences of Diseases (ICIDH) has provided internationally used definitions of disablement which have been accepted by the federal and most provincial governments in Canada and applied to programs and policies concerning PWDs. Although Wood's approach continues to make significant theoretical and methodological assumptions about disablement as a clinical category, which Jerome Bickenbach critiques, it nonetheless represents an attempt to clarify the muddied waters surrounding the conceptual aspects of disablement. ${ }^{18}$ Indeed, Bickenbach argues that the WHO's work marks a significant turningpoint in disablement theory simply because there was recognition that there are three conceptually independent dimensions of disablement (1993: 58)impairment, disability and handicap (See Figure 1).19 Prior to problematizing the assumptions inherent in the WHO's aefinition of disablement, I first want to describe these definitions in greater detail below.

The ICIDH defines impairment as "any loss or abnormality of psychological, physiological, or anatomical structure or function" (WHO, 1980: 27). Impairments, according to this definition are, disturbances at the level of the human organ which include defects or loss of limb, organ or other body structure, as well as defects or loss of mental function. Examples of impairments would inciude (but are not limited to): blindness; deafness; loss of sight in one eye; paralysis of a $\operatorname{limb}(\mathrm{s})$; amputation of a $\operatorname{limb}(\mathrm{s})$; loss of speech; and cognitive incapacities. It becomes evident then, that impairments can be temporary or permanent, minor or serious and are directly related to the nature and universal process of aging.

Disability is characterized as "any restriction or lack (resulting from an impairment) of ability to perform an activity in the manner or within the range considered normal for a human being" (WHO, 1980: 28). Like 
impairments, disabilities may be temporary or permanent, serious or minor, reversible or irreversible and linked to the process of aging. According to the $\mathrm{ICIDH}$, examples of disabilities include: difficulty seeing; speaking; hearing; moving; climbing stairs; grasping; bathing; eating. It is clear then that while impairments restrict organic functioning, disabilities have been defined as a restriction in the abilities and behaviours 'normally' expected of people (Bickenbach, 1993: 37). In this sense then, while an impairment may not affect an individual's behaviour, disabilities do so directly because they affect an individual's capabilities. As Bickenbach points out, the important distinction to be made here, is that the category of disability is "contingent on a variety of social, cultural and social-phychological factors" (1993: 39). This is particularly evident if you consider that this definition rests of what is "normal" for a human being. This is an inherently relational concept and as such this definition must be understood within similar parameters.

Handicap has been defined as a "disadvantage for a given individual, resulting from an impairment or disability, that limits or prevents the fulfillment of a role that is normal (depending on age, sex and social and cultural factors) for that individual" (WHO, 1980: 29). Handicaps, therefore, are socially created disadvantages brought about because of the way in which society receives/interprets both impairments and disabilities. As Bickenbach notes, the reception of impairments and disabilities are primarily attitudinal, but ultimately influence and impact the legal, bureaucratic, administrative, and policy responses of society's institutions which have been developed, by in large, to assist, in this instance, people with disabilities (1993: 48). It is clear then, that the handicapping process is subject to a variety of social, cultural, political and economic forces on an individual who is impaired and/or disabled. It also varies widely with technology and social organizing. For 
example, in a literate society dyslexia is a real handicap, but it is not if the society is based on oral traditions (e.g., some First Nations societies).

These definitions of disablement attempt to capture and operationalize the fact that disablement has both individual and social meaning. In short, they assist us in understanding that within the contemporary welfare state disablement is a variegated concept, process and category which affects and influences the whole of society-individuals with disabilities who are constructed by: formal administrative categories, 'big business', governments, social policy, health care, researchers, and so on.

Not surprisingly, the WHO's definitions have been subjected to considerable criticism from members of the medical profession, scholars and perhaps most importantly, PWDs themselves. Bickenbach locates his criticism of the WHO's definitions, not in any principled fashion, but rather in what he refers to as their "ideological commitment to two dubious methodological assumptions" (1993: 58). The first is simply that the three conceptions of disablement are independent, yet form a process which stems from each other; as a whole they are still grounded in the biomedical or medical model of disablement. Characterizing this as "the assumption of the biomedical grounding of disablement," Bickenbach argues that:

[A]lthough the consequences, for particular individuals, of disease conditions and other physical disorders will vary with the social environment, and so be subject to a host of social and socio-psychological forces, still the objective nature of the physical conditions themselves can (and must) be ascertained independently of all of these consequential, socially contingent phenomena (my emphasis, 1993: 25).

This implies therefore that disablement must have a biomedical component or more strongly, that each instance of an impairment, disability and/or 
handicap can be originally located in the physical condition of a particular individual.

Second, while these definitions attempt to capture the complexity of disablement as relational with many forces affecting it, the WHO's methodology assumes the neutrality of scientific investigation. Bickenbach states that "[the WHO] assumed without argument that all of the phenomena of disablement are susceptible to objective, normatively neutral scientific investigation" (1993: 29).

Jerome Bickenbach (1993) has located the major components of disablement social policy in Canada by attaching the WHO's disablement definitions to three corresponding models: the bio-medical model, the economic model and the social-political model.20 The bio-medical model focuses on the individual impairment dimension of disablement. Like the medical model, PWDs are understood as 'sick' and having a medical 'defect' or 'problem' which must be 'cured' with the aid of bio-medical science. Secondly, the economic model is conceptually grounded in the disability dimension of disablement. Disablement occurs, in this model, when a worker's productive capacities, abilities, and skills are limited because of an impairment, and therefore, cannot participate in the market-system. Whereas in the bio-medical model 'normalcy' resides within an individual's anatomical state, in the economic model it resides in the level and degree of an individual's labour-market productive capabilities.

Bickenbach concludes that the influence of the bio-medical and economic models of disablement on public policy in Canada and the United States means that they "can justifiably be called standard models" (1993: 13). Indeed, the assumptions inherent in both the bio-medical and economic modeis are evident in Canadian federal policies and programs such as: the 
workers' compensation program, the provision of disability-related supports, vocational rehabilitation, the Canada/Québec Pension Plan (C/QPP), the disability tax credit system, and the Canada Assistance Plan (CAP).21

While attaching social policy developments to the first two models is clear, the social-political model "has always been critical of the 'standard' models [bio-medical and economic], and adherents have made a point of presenting their understanding of disablement as iconoclastic" (Bickenbach, 1993: 179). This third model focuses on the handicapping conditions inherent in society and views disablement as a form of social injustice which can be attributed to the stigmatizing attitudes of society at large. This model, therefore, rejects the notion that PWDs are passive and 'imperfect' and conceptualizes PWDs as an oppressed non-ethnic minority group within society. As Bickenbach states, "the theoretical development that crystallized the social-poitical model arose simultaneously with the rise of political activism among people with disabilities" (1993: 50). In particular, this model raises the issue of self-definition, identity, and self-advocacy through the organizations of PWDs.

\section{V \\ The Disability Rights Movement and the Push to be Self-Defined}

In western countries the meaning and experience(s) of disablement have been influenced by political philosophy, medical and social science research, and most recently, it has been re-inforced through institutions of the contemporary welfare state. As Whyte and Ingstad maintain: “Concepts of personhood, identity, and value, while not reducible to institutions, are nevertheless shaped by them" (1995: 10). Beginning in the 1970s, however, PWDs began to reject their dependent position within the contemporary 
welfare state and their construction as passive, 'imperfect', 'ugly' and apolitical. A central component of disability movements has been a reinterpretation of the meaning and experience(s) of disablement. Indeed, René Gadacz argues that a central objective of the Canadian disability movement is "to reinterpret the meaning of disability" by rejecting "the assumptions upon which normative definitions of disability are built" (1994: 9). The pressure to reconceptualize disablement in a social rather than individual manner comes from disability movements and their efforts at self-definition.

The consumer disability movement and the Independent Living movement are both key forces attempting to shift disability discourse in Canada. Gadacz observes that,

The overall goals of the [disability] movement are to challenge and end...efforts of domination, to reclaim 'expropriated' bodies and to reappropriate the 'spoiled' identities that are a result of well-intentioned but generally ineffective medical and rehabilitation practices, misguided public policies and programs, bad laws and legislation and paternalistic attitudes (1994: 9).

As Jane Jenson details, the "self-naming" process is a central element of movement activity in general. She argues that "the struggle to represent oneself with a name of one's choosing is a crucial component of...movement politics" (1993: 339). For PWDs and their movements, the attempt to shift disability discourse has had a direct impact of the way in which they organize.

Since their inception, the Canadian consumer disability movement and the Independent Living movement have advocated the principles of selforganizing, self-advocacy and the necessity of organizing on a 'cross-disability' basis. As I discuss in greater detail in chapter two, cross-disability recognizes that while PWDs have different needs, they share a common goal of ensuring that programs and resources are accessible to persons with all types of disabilities. This represents a rejection of traditional approaches of organizing 
to server the needs of a specific medically-created disability type (e.g., individuals with spinal cord injury) were met while other types of disabilities were ignored. A cross-disability framework has been of central importance for disability movements because it brought together persons with all types of disabilities to form a collective disability identity and therefore to conceptualize disability away from medicaily-created and administered disease types. The push to be seif-defined by disability movements has also initiated within disability discourse a consideration of how disablement intersects with factors such as race, class, sex/gender, sexual orientation and geographic location/climate.

In Canada, the literature examining the theoretical relationships among race, class, sex/gender and disablement is scarce. 22 In recent years, however, some Canadian empirical evidence of women with disabilities has been produced by the DisAbled Women's Network (DAWN), the Canadian Research Institute for the Advancement of Women (CRIAW) and concerning First Nations peoples with disabilities by the National Aboriginal Network on Disability (NAND). But little theoretical analysis has been undertaken. René Gadacz (1994), for example, her book on the Canadian disability consumer movement, includes no discussion of race, class, sex/gender, sexual orientation or geographic location/climate.

Lennard Davis points out that, while scholars have been active discussing issues of race, class, and sex/gender, "the concept of disability is safely hidden on the sidelines away from much scrutiny" (1995: 158). In particular, he cites the unavailability of research which "connect" race, sex/gender and disability. British sociologist Michael Oliver notes the scarcity of material examining the ways in which sex/gender and race might structure the experiences of disability and disability identity (1990: 70). There is little 
material on disability and class, but Oliver notes "[j]ust as we know that poverty is not randomly distributed internationally or nationally, neither is impairment" (1990: 13). Davis concludes that "there is a very deep relationship between disability in general and class (1995: 85).

The central point is that disablement is not simply an area of study that can be factored into existing analyses other issues such as race, class, and sex/gender. As Davis suggests, "it is already there in complex and invisible ways":

Rather than being marginal, the issues around disability are central to the construction of normalcy: disability is tied to a process that defines us ali. Furthermore, disability is not, as is commonly thought, equally distributed throughout the population. People in the lower classes tend to be born with more disabilities and to acquire more disabilities than middleand upper-class people, and people of color [sic] tend to make up a disproportionate part of the poor. Women make up a disproportionate share of those who develop disabilities in midlife. Moreover, Third World countries tend to have many more people with disabilities than do developed countries (1995: 16162).

Up to this point, we have considered the way in which identity is constructed though seemingly universal factors. In Canada, however, space and environment play a prominent role in our lives and in our intellectual discourse. We must therefore, consider how territory/climate or spatial difference shapes identity, as well as the material experience of PWDs. Richard Cavell (1994) has convincingly shown, through a post-colonial interdisciplinary investigation, how 'Canadian space' addresses aspects of both "history" and "difference". 23 Cavell argues that space/territory directly contribute to the construction of Canadian identities, as well as to the material experiences of Canadians. 
I have already established that disablement is constructed through an array of social, political, cultural and economic factors. Lennard Davis, however, suggest that "spatial environment" (1995: 3) is also an important contributing element. Disablement is constructed differently in different regions and as between rural and urban areas. Climate, geographic and architectural barriers, population density, transportation systems, availability and location of medical and support services, housing, education and employment are all factors which directly relate to spatial difference. That is, PWDs tend to live in geographic areas which are defined by a high degree of overall accessibility. In other words, they most often live in urban areas which are in proximity to major transportation systems, educational facilities, a diverse housing sector catering to differing material needs, and a more developed sector of medical and disability-related support services. As well, urban areas often have a greater spectrum of cultural activities upon which PWDs can draw for support. Nevertheless, poverty may prevent some PWDs from re-locating to more accessible districts (e.g., First Nations peoples in the North) or those areas with more services and supports.

\section{VI}

\section{Conclusion}

In this chapter, I have sought to detail how political philosophy, modern medicine, social science research and the contemporary welfare state have collectively constructed PWDs as 'sick', imperfect, incomplete/nonpeople resulting in the denial of full citizenship rights and their conceptualization as inactive political beings. Further, I showed how PWDs and their organizations have fundamentally challenged and widened traditional understandings of citizenship and identity politics. 
In particular, I highlighted the relationship between medicalization, social science research and the development of administrative frameworks within the contemporary welfare state. Although PWDs secured some citizenship rights through the welfare state, these rights are nonetheless elaborated through a set of mostly medically grounded assumptions premised on the medical model of disablement. The emergence of disability movements organizing on their own behalf, however, signals a shift in disability discourse. Through the self-knowledge of PWDs, these organizations are asserting the principles of self-organizing, autonomous selfadvocacy and cross-disability. As well, they are re-interpreting the meaning and experience(s) of disablement tc include considerations of race, class, sex/gender, sexual orientation and geographic location and climate.

In chapter two, I present material on the emergence and development of disability movements in Canada and the United States. I comparatively examine the Independent Living movement, a central wing of disability selforganizing, to consider how different political environments affect the movement's goals, strategies, and organizational structures. 


\section{NOTES}

${ }^{1}$ Canadian treatments of movement activity have, for the most part, not included the disability rights movement in their investigations. See, for example, William K Carroll (ed), Organizing Dissent: Contemporary Social Movements in Theory and Practice. (Toronto: Garamond Press, 1992); Leslie Pal, Interests of State (Kingston: McGill-Queen's University Press, 1993).

${ }^{2}$ This investigation is concerned with PWDs and their movements in first world countries. It is important to note, however, that disablement exists in every society, but the impact disablement has on personhood varies. Ida Nicolaisen argues, for instance, that the relationship between disability and personhood in Central Borneo is different from that of western countries. She states, the "extent to which these impairments block the achievement of a full social life, of full personhood, varies from society to society" (1995: 52). See, Ida Nicolaisen, "Persons and Nonpersons: Disability and Personhood among the Puna Bah of Central Borneo," Disability and Culture Benedicte Ingstad and Susan Reynolds Whyte (eds), (Berkely: University of California Press, 1995).

3 See chapter three for a full definition of these terms.

${ }^{4}$ For a detailed account of social policy as it related to persons with cognitive disabilities, see, Harvey G. Simmons, From Asylum to Welfare, (Downsview: National Institute on Mental Retardation, 1982); in particular, on people with cognitive disabilities and the eugenics movement see pps. 59-64. For a general discussion on eugenics in Canada, see, Angus McLaren, Our Own Master Race: Eugenics in Canada, 1885-1945 (Toronto: McClelland \& Stewart, 1990).

${ }^{5}$ For more information on the influence of biomedical rehabilitation on persons with disabilities consult, McColl, Law \& Stewart, (1993); Lang, (1994); and McColl, Gerein and Valentine, (forthcoming).

6For a comprehensive analysis of social welfare in Ontario during the nineteenth century, see Richard Splane, Social Welfare in Ontario 1791-1893, (Toronto: University of Toronto Press, 1965).

7The term 'etiological' refers to the science that deals with assigning of causes.

8 Deviance theory is treated explicitly in Erich Goode, Deviant Behaviour, 2nd ed, (Englewood Cliffs, NJ: Prentice-Hall, 1984); E. Pfuhl, The Deviance Process, 2nd ed, (Berlmont, California: Wadsworth, 1986); and Allena E. Liska, Perspectives on Deviance, 2nd ed, (Englewood Cliffs, Nl: Prentice-Hall, 1987).

9 For a more detailed overview of deviance and PWDs, see, Edward Sagarin, Deviants and Deviance (New York: Praeger, 1975); Robert Bogdan and Douglas Biklen, "Handicapism," Allen D. Spiegel and Simon Podair (eds), Rehabilitating People with Disabilities into the Mainstream of Society, (Park Ridge, NJ: Noyes Medical Publications, 1981).

10 Kallen theoretical framework-the minority-rights concept-was first developed in her book, Ethnicity and Human Rights in Canada, (Agincourt, Ont: Gage, 1982), in which she discusses the minority concept from the perspective of racial and ethnic minorities. Her later work, Label Me Human: Minority Rights of Stigmatized Canadians, (Toronto: University of 
Toronto Press, 1989), Kallen presents the same analytic framework, but extends the analysis to include stigmatized non-ethnic minorities and human rights in Canada. These minorities include: people with disabilities, alcoholics and gays/lesbians.

${ }^{11}$ See Thomas Humphrey Marshall, "Citizenship and Social Class," Citizenship_and Social Development,(New York: Anchor, 1963).

${ }^{12}$ It is important to note there there are still some twenty countries in which women are not extended the franchise.

${ }^{13}$ The accessibility of polling stations and voting materials was legislated in Bill C-78.

${ }^{14}$ Tracking the number of veterans WHO came back from war with physical disabilities is difficult. We can get some idea of the numbers, however, by looking at the number of disability pensions which the Canadian government is responsible for. In 1945, there were 20,000 individuals receiving a disability pension, by 1950 this number had increased to 90,000 and by 1964 had peaked at just under 110,000. At end of fiscal year in 1991, that number had decreased modestly to 94, 520. See, Canada, Veterans Affairs, Ánnual Report, 1987-88, Ottawa: Supply and Services.

15 For a more comprehensive discussion en issues concerning women with disabilities, see DAWN. "Four Discussion Papers on New Reproductive Technologies." (Winnipeg: Canadian Disability Rights Council, 1990); Sandra Coundry, Women, Disability and the l.aw: Identifying Barriers to Equality in the Law of Non-Consensual Sterilization, Child Welfare and Sexual Assault, (Winnipeg: Canadian Disability Rights Council, 1994). On feminism and disability generally, see, Jenny Morris, "Feminism and Disability," Feminist Review. 43 (Spring, 1993): 57-70.

16I understand the term First Nations peoples to include treaty Indians and band members on and off reserve, those who status has been reinstated under Rill C-31, non-status Indians, and Métis on and off settlements. The concerns of First Nations pe,sples with disabilities have been largely ignored by government officials, academics and national disability organizations. Nevertheless, in the late-1980s the National Aboriginal Network on Disability (NAND) was formed to advocate on behalf of First Nations peoples with disabilities. There is a growing literature, see, for example, NAND. "Background of the National Aboriginal Network on Disability." Brief submitted to the Royai Commission on Aboriginal Peoples; Canada, Special Committee on the Disabled and the Handicapped, Obstacles: Follow-Up Report-Native Population, (Ottawa: Supply and Services, 1981); Canada, Standing Committec; and Royal Commission on Aboriginal Peoples, The Path to Healing, Report of the National Round Table on Aboriginal Health and Social Issues, (Ottawa: Supply and Services, 1993).

${ }^{17}$ National Film Board of Canada. "The Sterilization of Leilani Muir" (1996).

18 Bickenbach argues that although the ::'HO's definitions of disablement represent an advance in the theorization of disablement, they nonetheless make some theoretical and methodological assumptions. Although the definitions acknowledge wider social, political and economic factors affecting persons with disabilities, they remain grounded first in the physical condition of the individual. As well, the methodology used by the WHO revolves around the false neutrality of objective scientific investigation. See, Bickenbach (1993): 25-27. See also, Oliver (1990): 4-6. That said, Bickenbach recognizes that a component of the handicapping process must reside in biological fact. See Bickenbach (1993): 172-179. 
${ }^{19}$ For amore detailed discussion, see, Bickenbach, (1993): 23-60.

20 It is important to note that American political scientist Harlan Hahn was the first academic to develop this theoretical framework. To understand the complexity and multidemensional nature of disablement (as a human condition), Hahn argues that the history of disability policy (and all factors when stem from policy) can be reduced to three basic models. Moreover, he contends that with the development of each of these models, a group of 'experts' developed who alleged to know the true meaning of disablement. See, for example, Harlan Hahn, "Reconceptualizing Disability: A Political Science Perspective," Rehabilitation Literature, 45 (1984). More recently, Hahn reduced his analysis from three competing models to only twothe function-limitation model (which includes the biomedical and economic models) and the minority-right model (socio-political model). See, Hahn (1987); Harlan Hahn, "The Politics of Physical Difference: Disability and Discrimination," Lournal of Social Issues, 44, 1 (1988): 39 47.

${ }^{21}$ For a comprehensive discussion on the effect of the biomedical and economic models of disablement on public policy, see Bickenbach (1993): 73-81 and 108-119.

22For an excellent discussion of women with disabilities in the United States, see, Michelle Fine and Adrienne Asch (eds), Women with Disabilities: Essays in Psychology, Culture and Politics, (Philadelphia: Temple University Press, 1988). For treatments of women with disabilities in Britain, see, Jenny Morris Pride Against Prejudice, (London: The Women's Press, 1991).

23ro accomplish this, Cavell uses a postmodern, decontructivist approach by drawing on the work of the major thinkers within Canadian intellectual discourse including Northrop Frye, Marshall McLuhan, and Harold Innis. 


\section{CHAPTER TWO}

\section{DISABILITY MOVEMENTS IN CANADA: \\ Making Choices, Choosing Strategies}

\section{Introduction}

The disabled persons' movement has emerged as a truly 'new' form of movement organizing. Unlike the women's movement which had several 'waves' of organizing before the one which emerged in the 1960s, the disability rights movement, as a movement of people with various disabilities who organized on their own behalf, did not exist in any form prior to the 1970s. As discussed in chapter one, I understand the contemporary disabled person's movement as including organizations which began to emerge in Canada in the early-1970s and challenged the widely-held view that PWDs were passive, 'sick' and politically inactive. These groups are made up of and controlled directly by persons with physical, mental and sensory disabilities and were developed mainly in response to their marginalized position as 'clients' within the Canadian welfare state (primarily through disability-related services). In other words, it is a movement of PWDs who formed organizations on their own behalf to mobilize for citizenship rights.

It is my contention that the political environments in which movements emerge and develop significantly affects the kind of representational project they choose. ${ }^{1}$ This is especially true at the federal level. Pauline Rankin has characterized a representation project as "the process through which movements pursue representation through institutions of the state and civil society, as well as the process through which movements create and maintain new collective identities" (1995: 31). 
To uncover the way in which the Canadian political environment has affected the disability rights movement I will focus on the way in which Independent Living, as an organizational body and political strategy 'invented' in the Linited States, changed when it was transplanted to Canada; a country with a different political culture and a different political opportuniiy structure. I will compare the Independent Living movement in Canada and the United States focusing on the way in which the Canadian movement re-defined and conceptualized IL and pursued its goals through the institutions of the federal state and civil society. This analysis challenges many of the theoretical assumptions which currently inform most scholarly work on movements by grounding the disability movement's strategies and objectives in "Canadian realities" (Vickers, 1095). It will become evident that the disability movement is not simply a reactive movement that does what government tells it to; rather it makes choices and chooses strategies.

I begin by tracing the historical development of disability organizations through three periods: institutionalization, medicalization and postmedicalization. Next, I provide a detailed historical overview of disability organizing in the post-medicalization period, focusing on the development of the Canadian disability movement and its relationship with the federal state. In the third section, I explore the emergence and development of the U.S. disability movement, focusing on the U.S. Independent Living movement. I then trace the influence of the U.S. IL movement on disability organizing in Canada. In the fourth section, I examine the ways in which Independent living changed when it came to Canada. I focus on the Canadian IL movement's philosophy and structure and examine its formation, context and organizational development at the federal level. Finally, to account for the differences between the U.S. and Canadian movements I focus on the 
political opportunity structure in which disability movements operate in each country.

\section{I}

\section{Disability Organizing in Canada: Sketching the Periods of Mobilization}

The historical development of disability organizations is best understood by their classification into three periods: (1) the institutionalization period (1600-1900); (2) the medicalization period (1900)1970); and (3) the post-medicalization period (1970-present). While I survey each of these periods, this study is concerned with that collection of interrelated organizations that emerged and developed in the postmedicalization period and whose members defined themselves as undertaking organized advocacy of their own behalf (See Table 1).

In Canada, the institutionalization period began in the early nineteenth century with the establishment of public/charity asylums, hospitals and workhouses for the mentally ill, deaf, blind, poor, and aged. There purpose was not to 'cure' or medicalize individuals, but, as Richard Splane suggests in his study on social welfare in Ontario during the nineteenth century, to keep them 'hidden' from the rest of society partly because they were deemed 'undesirables' and 'incurable' or they were deemed to require 'protection' (1965: 203-207). In the case of blind and deaf individuals, institutionalization was for the purpose of their education. Medicalization was not a feature in this period simply because throughout most of the nineteenth century medical professionals had low status vis-à-vis other professionals. In fact, most people had more confidence in home remedies than those prescribed by physicians (McLaren, 1990: 28). 
The measures taken to secure educational institutions for deaf and blind individuals in Upper Canada dates back to 1839 when more than hundred residents of the Eastern District petitioned the government on "the deprived state of the deaf child, the effect special education could have on his [sic] life and the strong desirability of securing such education for the deaf children" (Splane, 1965: 200). These petitions continued into the Confederation period and in 1870, the newly formed province of Ontario established the first separate institution for deaf and blind children in Belleville. The following year, another institution was built in Brantford and in 1873 , legislation was passed stating that the institutions were "for the purposes of educating and imparting instruction in some manual art" (Splane, 1965: 201).

\section{TABLE 1}

Historical Periods in the Classification of Disability in Canada (1600s-present)

1600-1900s

INSTITUTIONALIZATION

- medical profession has little influence

- institutionalization in public and charity asylums, hospitals

- focus was on education, employment activities, protection for 'incurables'

- there were no disability organizations

1900-1970s MEDICALIZATION

- limited welfare state-mainly local level

- disability developed as a clinical concept and formal administrative category-search for a 'cure'

- PWDs were deemed sick and passive

- war issues propelled the development of disability rehabilitation organizations

- disability organizations emerged for PWDs

- single focus disability organizations prevailed

1970-present POST-MEDICALIZATION

- PWDs reject the medicalization and rehabilitation of their bodies

- advocacy and service-orientations organizations of PWDs emerged

- principles of self-autonomy, self-determination and cross-disability

- mature welfare state resulting in neo-liberal reaction

Note: There is overlap between these historical periods. 
In the 1840s, the legislature of Upper Canada passed an Act to "authorize the erection of an Asylum within the Province, for the reception of Insane and Lunatic persons" (Splane, 1965: 204); the first hospital opened in Toronto in 1850 and by 1893 there were five such institutions in the Province caring for 4,240 individuals (Splane, 1965: 207). Like the institutions built for deaf and blind individuals, the focus of the asylums was not primarily on medical intervention, but rather on "the maximum development of recreation and employment...activities" (Splane, 1965: 207). John Radford in his discussion on the history of intellectual disabilities notes that the carliest mental handicap asylums were founded in a period of intense optimism "around new ideas about the educability of 'idiots" (1994: 13).

By the turn of the twentieth century, however, medicalization was gaining a foothold. The state was under great pressure to deal with the consequences of rapid urbanization, industrialization, and immigration. As Angus McLaren details in his book on the history of the eugenics movement in Canada, one perceived solution was to employ professionals, including physicians, to "deal with threatening social problems" (1990: 29). The inclusion of medical professionals in the social policy process dramatically increased their influence over Canadian society. For PWDs and others the impact of the eugenics movement was pronounced. State policies flowing from the eugenics movement sought to limit the reproduction of PWDS through sterilization because medical doctors deemed most PWDs to be degenerates who were spreading immorality, promiscuity and improvidence. ${ }^{2}$ In contrast to Marshall's idea of people progressively acquiring new aspects of citizenship rights, PWDs actually lost civil rights in this century. 
The First World War further advanced the medical profession's standing. The state required 'healthy' men to fight the war and doctors seized the opportunity to determine those who were 'fit' and those who were not. As well, it was doctors who were responsible for the care of individuals disabled by war. As a result, a new relationship between the state, the medical community and PWDs emerged. 3 War has always figured prominently in the lives of PWDs, but the First World War resuited in the incidence of disablement significantly increasing in Canada and the U.S. and since these (mostly) men had become disabled by serving their country in war, the state had an obligation to respond to the their needs. Governments responded to the number of veterans coming back from war with physical disabilities ty fostering the development of disability-specific, medically-oriented organizations (Scotch, 1988; Driedger, 1989). As well, disabled veterans developed their own organizations such as the War Amps and Justice for Veterans to lobby the state for better care and pensions.

With the Second World War and later the Vietnam war, however, the number of young people who became disabled escalated. We can also attribute the increase in the number of people with disabilities in both Canada and the U.S. to technological innovations which meant that people who would have died due to their disablement (polio, spinal cord injuries, accidents) were now living much longer, as well as to better neonatal techniques which saved babies who earlier would have died. Technological advances also meant the development of better wheelchairs and prosthetics resulting in increased mobility and independence for PWDs. As well, increased urbanization meant better services, paved roads and sidewalks, and increased transportation was available to some PWDs. 
This period was also marked by a rapid increase in the number of rehabilitation professionals (doctors, physiotherapists, nurses, social workers, occupational therapists) and institutions which linked medical procedures and rehabilitation techniques. Scholars in Canada and the United States argue that the underlying assumption of rehabilitation techniques during this period was that PWDs were 'sick' and medical intervention could cure or alleviate the problem (Driedger, 1989; Gadacz, 1994; Scotch, 1988). As Driedger notes, the development of the rehabilitation profession "led to many more rehabilitated people, but it also medicalized all aspects of life for disabled persons by classifying them as sick" (1989: 74). It becomes clear that, although the commitment to rehabilitation increased the mobility of persons with physical disabilities, it re-inforced the 'dependency' assumptions about PIVD. Moreover, the rehabilitation and reintegration process did not extend to all kinds of disabilities (i.e., people with cognitive disabilities) and included no focus on the economic needs or political concerns of PWDs.

The 1950 s were marked by the development of a loosely-defined collective disability consciousness among some PWDs. While PWDs had not yet formed political organizations on their own behalf, the development of parent's and athletic organizations during this period did provide a forum for persons with disabilities to interact with one another and form an early level of 'disability group' consciousness (Driedger, 1984; 1989). More specifically, this included the formation of parent's organizations (primarily advocating better and more suitable education for their children or fundraising for research and 'cures'), as well as sports associations of mostly young men who demonstrated that PWDs still had athletic abilities. A person with a disability who was educated and/or athletic challenged the 'sick role' defined by the rehabilitation professionals and at the same time 'fit' their predetermined 
goals. In other words, through athletic abilities these individuals showed that PWDs were not passive and at the same time reinforced the 'normalizing' gaze of the rehabilitation profession; that is, people with physical disabilities who participated in sports were a 'little bit more normal' than those individuals who did not participate.

In this period, the Canadian state tried to deal with the significantly increased level of disablement among its citizens by fostering the rapid development of single-disability organizations. Some organizations, however, were founded prior to this period; the Canadian National Institute for the Blind (CNIB) is one such organization, founded in 1918. As well, some of these organizations like the March of Dimes for example, first emerged in the United States and were subsequently transplanted to Canada. ${ }^{4}$ Of importance, these organizations were controlled by professionals (not by people with disabilities) and were primarily concerned with the perceived needs of a single disability group (i.e., people with spinal cord injuries, blindness, etc.). Moreover, these groups were (and many continue to be) inherently paternalistic in their approach to the allocation of disability-related services.

Ultimately these national organizations for people with disabilities also formed international associations. As Driedger notes, in her study of international disability organizing, "international organizations were formed composed of national non-profit organizations interested in the prevention of disability and the integration into society of people with one disability or another" (1989: 9). Although the globalization of disability organizations began in the early 1920s with the formation of the International Society for Crippled Children (later re-named Rehabilitation International), it was 
during the 1950s and 1960s that the main development of international organizations occurred (see Table 2). ${ }^{5}$

The influence and power these groups have over the lives of PIVDS is considerable. They were controlled by state-sanctioned professionals who had the full support of governments and international non-governmental organizations (NGOs). Michael Prince, in his study of international influences of Canadian disability social policy has identified four common feciures:

- they focus on a single type of disability;

- PIVDs do not control decision making since most organizations were founded and managed by parents or rehabilitation professionals acting on their behalf;

- the underlying ideology which informs their work combines charity, paternalism and the bio-medical mociel; and

- they have links with the United Nations (1992: 196-7).

\section{TABLE 2}

Canadian and International Non-Governmental Organizations Representing People with Disabilities

\begin{tabular}{|c|c|}
\hline Date Founded & Organization \\
\hline 1918 & Canadian National Institute for the Blind (CNIB) \\
\hline 1920 & $\begin{array}{l}\text { Amputation Association of the Great War (renamed the War } \\
\text { Amps of Canada in 1965) }\end{array}$ \\
\hline 1922 & $\begin{array}{l}\text { Rehabilitation International (originally, the International } \\
\text { Society for Crippled Children) }\end{array}$ \\
\hline 1945 & Canadian Paraplegic Association (CPA) \\
\hline 1948 & World Federation for Mental Health \\
\hline 1951 & $\begin{array}{l}\text { March of Dimes (originally, the Canadian Foundation for } \\
\text { Poliomyelitis) }\end{array}$ \\
\hline 1951 & World Federation of the Deaf (WFD) \\
\hline 1960 & $\begin{array}{l}\text { International League of Societies for Persons with Mental } \\
\text { Handicaps }\end{array}$ \\
\hline 1962 & Canadian Rehabilitation Council for the Disabled (CRCD) \\
\hline 1964 & International Federation of the Blind (IFB) \\
\hline 1969 & International Cerebral Palsy Society \\
\hline
\end{tabular}

Source: Complied by author from Driedger, (1989), Prince, (1992), and original research.

As I detail in the next section, however, the rise of equality-secking and quality-of-life movements began to change the Canadian political landscape. 
In particular, PWDs, in response to their dependent position began to form organizations on their own behalf. The emergence of equality-seeking disability organizations in Canada, therefore, marks the beginning of the postmedicalization period.

\section{II}

The Post-Medicalization Period:

\section{An Historical Overview of Disability Organizing in Canada}

\section{Local Disability Organizing in the late-1960s}

The paternalism towards persons with disabilities began to be challenged in Canada in the late-1960s and 1970s. Using the network established through sports and recreational associations, PWDs began openly to question and discuss the 'dependent' situation in which they found themselves realizing the extent to which their situation was defined by others (Gadacz, 1994: 64). Local consumer-type disability organizations first developed in Edmonton in 1969 when PWDs united to lobby municipal council on issues relating to accessibility. By 1971, the Edmonton Action Group of the Disabled was formed and lobbied municipal council on issues relating to architectural accessibility. Similar local groups began to emerge during this period in cities across Alberta including: Calgary, Lethbridge, Grand Prairie and Camrose. With the support of the provincial government, these local groups merged to form the Alberta Committee of Action Groups. ${ }^{6}$

\section{Provincial Disability Organizing in the $1970 s^{7}$}

Provincial consumer disability organizations arose because most things the local consumer groups were lobbying for (i.e., transportation, architectural accessibility, housing) were controlled at the provincial level. ${ }^{8}$ Following the 
establishment of the Alberta Committee, the formation of the Saskatchewan Voice of the Handicapped was spearheaded by the Saskatchewan Coordinating Council on Social Planning and Core Services Administration in 1973. A year later, the Manitoba League of the Physically Handicapped formed and throughout the 1970s consumer disability organizations developed in a majority of Canadian provinces. (Siee Table 3).

\section{TABLE 3}

Canadian Provincial Consumer Disability Organizations in the $1970 \mathrm{~s}^{4}$

\begin{tabular}{|c|c|c|}
\hline Province & Date Founded & Organization \\
\hline Alberta & 1973 & Alberta Committee of Action Groups \\
\hline Saskatchewan & 1973 & $\begin{array}{l}\text { Saskatchewan Voice of the } \\
\text { Handicapped }\end{array}$ \\
\hline Manitoba & 1974 & Manitoba League of the Physically \\
\hline Prince Edward Island & 1974 & PEI Cuuncil of the Disabled \\
\hline Newfoundland & 1975 & $\begin{array}{l}\text { The Hub, Physically Handicapped } \\
\text { Service Centre }\end{array}$ \\
\hline \multirow[t]{2}{*}{ Ontario } & 1975 & $\begin{array}{l}\text { Blind Organizations of Ontario with } \\
\text { Self-Help Tactics }\end{array}$ \\
\hline & 1978 & $\begin{array}{l}\text { United Handicapped Croups of Ontario } \\
\text { (later re-named Persons United for Self } \\
\text { Help) }\end{array}$ \\
\hline British Columbia & 1975 & $\begin{array}{l}\text { British Columbia Coalition of the } \\
\text { Disabled }\end{array}$ \\
\hline Québec & 1976 & $\begin{array}{l}\text { Comité de liaison des handicapés } \\
\text { physiques du Québec }\end{array}$ \\
\hline Nova Scotia & 1978 & $\begin{array}{l}\text { Nova Scotia League for Equal } \\
\text { Opportunities }\end{array}$ \\
\hline New Brunswick & 1979 & Centres Offering Independent Living \\
\hline
\end{tabular}

Source: Driedger, (1984); Prince, (1992).

Driedger's research has shown that the emergence and development of the consumer disability movement can also be attributed to activities undertaken by the then federal Minister of Health, Marc Lalonde and a federal agency, the Canadian Rehabilitation Council for the Disabled (CRCD). Partly under growing international pressure because of movement organizing in the United States, Lalonde, in 1972, called for social service agencies "to start talking with disabled persons themselves concerning their 
needs" (Driedger, 1984: 4). In 1973, the CRCD responded to Lalonde's request by sponsoring a national conference in Toronto in November of 1973 . Its mandate was framed so that "disabled persons' [could have] involvement in their organization [the CRCD]" (Driedger, 1984: 3) through the establishment of a national advisory committee comprised of representatives with disabilities within the CRCD. The committee would represent the views of Canadians with disabilities on policy matters to the federal government. While the committee was never formed, the government's actions point to some important insights.

A year prior to Lalonde's urging the CRCD to include PWDs in its administrative activities, the Report of the Royal Commission on the Status of Women (RCSW) had been released (in 1971). As I discuss in chapter three, the impact of the RCSW on the federal government, while not as broad-based as some would have liked (Findlay, 1987), nevertheless was significant in terms of establishing some new administrative arrangements and involving women more in some decision-making processes. Women were appointed as policy advisors within the bureaucracy and there was a broadening of the role of government vis-à-vis the Canadian citizenry (Burt, 1986; Findlay, 1987). Leslie Pal maintains the government's motivation was to foster "the development of a citizenry attached to a single identity [being Canadian] through their differences" (1993: 122).

While these measures did not directly impact PWDs, they help explain government's willingness to include PWDs directly in consultative bodies. At the CRCD conference in 1973, approximately one hundred PWDs from across Canada were provided with travel subsidies from the federal government to attend the conference. Many of these individuals were involved in the Alberta Committee of Action Groups and the Saskatchewan 
Voice of the Handicapped. Individuals from other provinces who attended the conference soon recognized the validity of self-organization and, more importantly, gained legitimization from the already established provincial consumer disability groups. It seems that the conference, while not establishing an advisory committee within the CRCD, successfully linked persons with disabilities from across the country. Common issues were identified and defined and principles of public education and networking were established. As Driedger notes, people left the conference feeling "inspired by their actions and words" (1984: 4).

In fact, the individuals attending the CRCD conference were largely responsible for the formation of the Manitoba League of the Physically Handicapped. Once established, the Manitoba League organized, in October of 1975, the first Canadian conference run by persons with disabilities for PWDs. Up to this point, 'professional' organizations held conferences, meetings, and roundtable's without the involvement or participation of persons with disabilities. The conference was held in Winnipeg and most of the funding was secured from grants through the Voluntary Action program at the Secretary of State. PWDs from across the country were brought together to discuss common issues and concern: accessible public transportation, housing, public education, architectural barriers and human rights concerning persons with disabilities. As Driedger observes, the Manitoba League conference established "a feeling of mutual moral support...between the disabled people of the difference provinces in the struggle to break away from public and governmental stereotyping about disabled people" (1984: 5).

The conference established an understanding between all the individuals involved in the western consumer disability groups that information sharing was imperative because it would give a "moral boost to 
the momentum of the disabled persons' 'consumer' movement" (Driedger, 1984: 6). They formed the Western Alliance composed of provincial groups from Alberta, Saskatchewan and Manitoba. In January of 1976, the Western Alliance met in Saskatchewan to discuss its structure, mandate and objectives. All participants agreed that the structure of the Western Alliance was too limited, and instead, they formed the first pan-Canadian consumercontrolled disability organization.

Pan-Canadian Disability Organizing in the 1970s: The Developinent of the Coalition of Provincial Organizations of the Handicapped

The Coalition of Provincial Organizations of the Handicapped (C.OPOH) was founded in 1976 as a pan-Canadian coalition of autonomous consumer-controlled provincial disability organizations and was supported by the federal government. ${ }^{10}$ This organization was founded to enable sharing and cooperation at the federal level while still maintaining autonomous provincial bodies (Driedger, 1984: 7). COPOH's purpose was to:

- develop policies on national issues concerning persons with disabilities;

- act as an advocate and lobby force at the federal level on legislative policies;

- provide a national information sharing vehicle;

- monitor existing legislation, policies and service delivery systems relating to the needs of disabled citizens; and

- ensure that the input of disabled people be heard in the federal decision-making processes as these relate to the concerns of persons with disabilities (Driedger, 1984: 7-8).

$\mathrm{COPOH}$ was involved with architectural accessibility, the establishment of an accessible public transportation system across Canada, development of accessible housing, efforts to improve employment opportunities through job creation and policy change initiatives, and changes in human rights legislation (Enns, 1981; Driedger and D'Aubin, 1985). In 1979, for example, 
$\mathrm{COPOH}$ was actively involved in hearings of the Canadian Transport Commission and later was a central member of the Advisory Council to the Minister of Transport under the Liberal government. C.OPOH's involvement in these bodies led to the increased accessibility of VIA Rail, federal airports and the Parliament Buildings which until 1979 were architecturally inaccessible (Driedger, 1984: 16). ${ }^{11}$

Although the work COPOH has undertaken since it was formed in 1976 is significant, perhaps its greatest achievement was its role in securing the inclusion of 'disabled persons' in Section 15 (1) (2) of the Canadian Charter of Rights and Freedoms (1982)12, as well as the Canadian Human Rights Act (1983). COPOH was actively involved in the hearings before the Special Joint Committee of the Senate and the House of Commons on the Constitution of Canada (the Hays-Joyal Committee). ${ }^{13}$ In their presentation to the federal Joint Committee on the Constitution of Canada in November of 1980, $\mathrm{COPOH}$ representatives argued that:

...constitutional protection of the rights of disabled people would give high symbolic profile to the social concern to recognize and protect their rights. It would set the tone for an improved future (as quoted in Driedger, 1984: 38).

Their argument was successful and PWDs had "bestowed" on them formal legal status as full citizens with citizenship rights. Nonetheless, as I argued in chapter one, individuals can still be denied full social membership despite gaining formal or legal citizenship status.

In 1993, COPOH was renamed the Council of Canadians with Disabilities (CCD) and remains a federal umbrellalt organization comprised of a coalition of 14 provincial groups located in a majority of Canadian provinces; there are no members from either of the territories (See Table 4). ${ }^{15}$ During the same year, however, CCD broadened its structure by enabling 
"groups of ten or more self-determining disabled persons" to join the federal organization as 'associate members' (COPOH, 1994: 1). ${ }^{1 \mathrm{t}}$ It is interesting to note that NAC, the women's umbrella organization which began provincial organizations, passed a similar resolution in the early-1970s. As a panCanadian organization, CCD continues to acts as a 'watchdog' concerning the services provided to persons with disabilities by the federal government, as well as putting pressure on the federal government to recognize the collective/group concerns of Canadians with disabilities. In 1993, CCD received $\$ 470,000$ core funding from the Secretary of State and an additional $\$ 240,097$ in project funding from the Canadian International Development Agency (CIDA), the Canada Communications Group, the Finance Department and Transport Canada (CCD, Annual Report, 1992-93).

TABLE 4

Provincial Members of the Council of Canadians with Disabilities (1995)

\begin{tabular}{ll}
\hline Province & Organization \\
British Columbia & British Columbia Coalition of People with Disabilities \\
& DisAbled Women's Network Canada \\
Alberta Committee of Citizens with Disabilities & The Manitoba League of the Physically Handicapped \\
Maniloba & Saskatchewan Voice of the Handicapped \\
Saskalchewan & Canadian Association of the Deaf \\
Ontario & Thational Education Association of Disabled Students \\
& The National Network for Mental Health \\
& Thalidomide Victims Association of Canada \\
& People First \\
Quebec & Confederation des Organismes Provinciaux de Personnes \\
Nova Scotia & Handicapées du Quebec \\
Prince Edward Island & PEl Council of the Disabled \\
Newfoundland & Consumer Organization of Disabled People of Newfoundland \\
& and Labrador
\end{tabular}

Source: CCD, Annual Report (1995).

When $\mathrm{COPOH}$ emerged in 1976 it challenged many ideas commonlyheld by medical/rehabilitation professionals and government officials 
concerning PWDs. Prior to the emergence of the pan-Canadian consumer disability movement, the aspirations (political or otherwise) of people with disabilities were firmly controlled by professionals or parents who spoke and acted on their behalf. COPOH/C.C.D, on the other hand, represented a coalition of provincial groups composed of and controlled by PIVDs speaking for themselves. Moreover, $\mathrm{COPOH} / \mathrm{CCCD}$ challenged the historic notion that grouped people with disabilities together according to the type and extent of their disability(ies). COPOH was the first pan-Canadian disability organization which was cross-disability 17 ; that is, it was open to all people with all kinds of disabilities. For the first time, the medical community, and later the Canadian state, had to recognize that PWDs were forming their own organizations and acting as autonomous political actors through their collective consciousness.

The cross-disability focus of the Canadian consumer disability movement is an important factor in the advancement of a collective disability consciousness. Prior to the development of cross-disability organizations, PWDs were fragmented and largely unorganized except indirectly through a number of disability-specific groups (Kallen, 1989: 146-47). This fragmentation is due, in large part, to the medical model which creates categories of individuals depending on th:ir 'type' of disability. As Ciadac\% notes, a cross-disability focus is a "direct effort to counteract and overcome the fragmenting consequences of the medical/rehabilitation model" (1994: 131). There is recognition that PWDs, as a group, face similar oppressive conditions regardless of their specific physical or mental state. 


\section{Pan-Canadian Disability Organizing in the 1980s:}

The Emergence of Canadian Independent Living Movement

Shifting our attention to the Canadian Independent Living Movement and its federal organization, CAILC, we see the emergence of a somewhat different, yet interrelated, network of consumer-controlled organizations. Independent Living has been characterized as a philosophy (DeJong, 1979; DeLoach et. al, 1983; Driedger and D'Aubin, 1985), a process (Denson, 1988), a service delivery model (DeLoach et. al, 1983; Crewe et. al, 1983; Bickenbach, 1993) and, finally, a political strategy (DeJong, 1979; Scotch, 1988; Driedger, 1989; Oliver, 1990; Bickenbach, 1993; Gadacz, 1994). Each assessment has some validity, but the diversity has created ambiguity about IL.

Unlike $\mathrm{COPOH}$ and its affiliates, the Independent Living movement (which is comprised of CAILC and its member ILRCs) do not engage in collective advocacy. Instead, the IL movement promotes an end to institutional living for PWDs and encourages and supports PWDs to integrate into the community (Lord et. al., 1992). The Canadian IL movement does not assume a counter-hegemonic position vis-à-vis the federal state, but instead offers an alternative model for disability-related supports and services. In short, the movement rejects the medical model and stresses the process of 'normalization', deinstitutionalization, and integration. While the aim is not to make a person 'normal' in a physical or mental sense, the movement emphasizes the "value of people with disabilities to have ordinary life experiences" (Gadacz, 1994: 167). The Independent Living movement, as it was 'invented' in the U.S., provides community-based, consumer-controlled services, supports, resources and skills training to PWDs enabling them to live an "ordinary life" in the community. ${ }^{18}$ 
In Canada, the philosophical base of the idea of Independent Living is operationalized through five guiding principles and four programs which are offered through the pan-Canadian network of ILRC.s. The IL principles are discussed below:

Consumer Control means that all services will be controlled by a majority of PWDs and PIDDs have a high degree of choice in individual services which they receive. This principle responds to services which have historically been dominated by professionals.

Cross-Disability means that the ILRCs work towards responding to the personal needs of all PWDs who request their services, regardless of their 'disability-type'. This principle responds to more traditional services which emphasis a single type of disability over individuals needs and abilities.

Community-Based means that the ILRCs respond to unmet community-based needs as they are identified by those individuals who support IL, especially PWDs. This principle responds to more traditional decision-making processes which have been 'top-down' rather than 'grassroots' in their approach.

Integration means that the ILRCs promote the full participation of PWDs in the community. This principle responds to the historic segregation and isolation which most PWDs have experienced.

Non-profit means that the ILRCs function to meet their goals and objectives rather than make a profit. This principie responds to the need for affordable services and programs (Lord and Osborne-Way, 1987: 25).

These five guiding principles are elaborated and operationalized through four core program areas which each ILRC is mandated by CAILC to offer. It is through these program areas which the idea of Independent Living fosters the development of personal IL skills and new service delivery models (CAILC, 1994a: 8). ${ }^{19}$ They include:

Information and Referral provides relevant information and referrals to PWDs and the public about services, programs, products, supports and issues affecting Canadians with disabilities; 
Peer Support provides a supportive environment for PWDs to share and exchanges ideas and experiences;

Individual Empowerment provides for the development of individual self-management skills enabling them to speak and act of their own behalf; and

Research and Service Development identifies (through research) and responds to (through demonstration projects) unmet needs in the community (CAILC, 1992; Lord et. al., 1992).

The IL movement was 'invented' as a political strategy in the U.S. where most aspects of the welfare state are weakly developed. IL emerged out of a political environment defined by U.S. 'New Left Thought' which was both anti-institutional and anti-state (Sayers, et. al., 1984; Teodori, 1969).20 The movement emerged to establish alternative machinery outside of institutions on which PWDs could draw for support. The U.S. IL movement is firmly rooted in U.S.-style liberal values and ideals. Michael Oliver has suggested that "IL reflects the American penchant for seeing all social problems in terms of legally enforceable individual rights" (in Bickenbach, 1993: 156). The historical pursuit of 'individual rights' in the United States is an important aspect of the emergence of the U.S. Independent Living movement on which I expand later in this chapter.

In its U.S. origins, Independent Living did not represent a movement seeking revolutionary changes in society and was not based on a counterhegemonic agenda. In other words, in the U.S. Independent Living operates within the existing parameters of the U.S. state and civil society. The movement's radicalism was in the challenges it presented to existing ideas about PWDs. The IL model of service delivery represents a significant transformation of more traditional rehabilitation-focused service delivery systems. Gerben DeJong (1979) argued, for example, that the IL model represents a paradigm shift in social service provision for persons with 
disabilities-from a rehabilitation paradigm to an Independent Living paradigm ${ }^{21}$ (See Table 5). The IL paradigm is said to provide PIDS with control over the resources which affect their daily lives, such as the ability to hire and fire personal attendants and the ability to control personal financing of disability-related supports.

\section{TABLE 5}

Comparison of Rehabilitation and Independent Living Models

\begin{tabular}{l|l|l}
\hline \multicolumn{1}{c|}{ Item } & \multicolumn{1}{c}{ Rehabilitation Paradigm } & \multicolumn{1}{c}{$\begin{array}{c}\text { Independent Living } \\
\text { Paradigm }\end{array}$} \\
Definition of Problem & $\begin{array}{l}\text { Physical lmpairment/lack of } \\
\text { vocational skill } \\
\text { Lndividual }\end{array}$ & $\begin{array}{l}\text { Dependence on professionals, } \\
\text { relatives, etc. } \\
\text { Environmental/ Rehabilitation } \\
\text { process }\end{array}$ \\
Solution to Problem & $\begin{array}{l}\text { Professional intervention by } \\
\text { physician, therapist, vocational } \\
\text { rehabilitation and/or counseling } \\
\text { Consumer/Citizen }\end{array}$ & $\begin{array}{l}\text { Peer counseling, advocacy, self- } \\
\text { help, consumer control and skills } \\
\text { development }\end{array}$ \\
Social Role & $\begin{array}{l}\text { Consumer/Citizen } \\
\text { Patient/Client }\end{array}$ \\
Who controls? & $\begin{array}{l}\text { Maximum developed level } \\
\text { and/orgainful employment }\end{array}$ & Professional \\
Desired Outcome & Independent Living
\end{tabular}

Source: Dejong, (1979): 443.

DeJong argues that the IL model of service delivery advocates deprofessionalization of services for PWDs and a move from institutional living to community-living. Unlike more traditional modes of service delivery, Independent Living is a process of enabling people to see their own potential, exercise their own choices and participate fully in their own lives. As I discussed above, Independent Living Resource Centres, consequently, are the structures which enable PWDs to develop the skills necessary to move into community-living settings. This is accomplished through the provision 
of core program areas-peer support, individual empowerment, information and referral and continual research and service development. Each of the program areas, it is argued, is a different way of promoting and facilitating individual self-determination and autonomy from more traditional forms of institutional control.

The development of the Independent Living idea in Canada at the federal level can be attributed to a still influential report tabled in Parliament by the Special Committee on the Disabled and the Handicapped entitled, Obstacles (1981a). Responding to the United Nation's declaration of the International Year of Disabled Persons (IYDP) in 1981, the federal government established the Special Committee, which became the Standing Committee on Human Rights and the Status of Disabled Persons in 1987. To date, the Committee has tabled eight reports concerning Canadians with disabilities (See chapter three). ${ }^{22}$ The Special Committee was to evaluate the scope and effectiveness of existing government programs for PWDs and to suggest new ways of improving services the federal government provided to Canadians with disabilities. The 1981 report was considered the most comprehensive research undertaken on disablement in Canadian society containing some 130 recommendations in 20 issue areas. 23 The recommendations emphasized the social and economic aspects of citizenship and the extension of social, civic and political rights to persons with disabilities (Prince, 1992: 208).

In 1980, members of the Special Committee traveled to the United States to visit the Centre for Independent Living in Bositon and meet with U.S. federal officials, it was during this trip that Committee members were convinced that Independent Living was a model to support in Canada. Although they argued that there could not be a direct transfer of the U.S. experience to Canada given the differences in government structure, they 
nevertheless concluded that "the knowledge that independent living is successful wherever it has community support and services" could be transferred to Canada (Obstacles, 1981a: 80). The result was the inclusion of recommendations which called for the development of and federal support for Independent Living in Canada. The first Canadian ILRC opened in Waterloo, Ontario in the early 1980s and by 1985, five Centres were operating (or in the development stages) in cities across Canada: Waterloo, Toronto, Thunder Bay (all in Ontario), Winnipeg, (Manitoba), and Calgary, (Alberta).

While the Obstacles report assisted in legitimizing the growth of the Independent Living movement, the IL concept was strongly advocated by the existing consumer disability movement. In June of 1980, COPOH held its Third National Conference in Vancouver, entitled Defining the Parameters of Rehabilitation. This conference marked the formal introduction of IL principles to Canadians with disabilities. U.S. scholar Gerben DeJong was invited by Canadian consumer disability activists to address conference delegates on the principles of the U.S. IL movement. It was here that Canadians involved in the consumer disability movement learned of the IL principle and model. In the same year, $\mathrm{COPOH}$ adopted a policy resolution endorsing the promotion of the Independent Living concept in Canada.

WHEREAS the involvement by the consumer is a vital part in any system which is responsive to the real needs of the people it serves, THEREFORE BE IT RESOLVED that COPOH endorses the independent living model and direct its efforts to the implementation of the Independent Living Philosophy in all appropriate programs and services related to the disabled in Canada... (in Gadacz, 1994: 79).

The Canadian Independent Living movement formally established itself in May of 1986, with the formation of the Canadian Association of Independent Living Centres (CAILC). CAILC was developed by the existing 
five Canadian ILRCs to act as a federal representational body. It was supported financially through $\mathrm{COPOH}$ and some federal government project contributions from the SOS. A year prior to the founding of CAILC, in January of 1985, the five existing ILRCs developed and adopted a Canadian definition of an ILRC. Centres were mandated to "promote and enable the progressive process of citizens with disabilities taking responsibility for the development and management of personal and community resources" (CAILC, 1989a: 2). The objectives of the Independent Living movement, therefore, are to promote and achieve citizenship, equality, selfdetermination and full participation of persons with disabilities in Canadian society (CAILC, 1994a).

As I discuss in greater detail below, the emergence of Independent Living out of the Canadian consumer disability movement is an important factor which continues to influence the focus and path of IL in Canada. The U.S. IL model is premised on the provision of an alternate set of communitybased, disability-related services. But in Canada Independent Living has never reflected the 'hard' service-delivery orientation of the U.S. movement. While there is some service provision at Canadian ILRCs, most of the movement's organizational energy has centered on individual skills development and disability-led research initiatives. Members of the disability movement did not want to get 'involved' in the provision of services because they felt as citizens of the Canadian welfare state it was the responsibility of governments to provide these services (Driedger, 1989: 6).24 Nevertheless, there is evidence to support the idea that the Canadian state endorsed the concept of Independent Living partly because of its service-orientation. Indeed, in the early-1980s, the federal government had undertaken a federal/provincial social services review which resulted in a willingness to 
explore alternative models of service delivery. This resulted in a push towards de-institutionalization projects. Independent Living, as it turned out, gained federal support because it represented such a project. 25

Prior to 1988, CAILC and its affiliates were funded through a mix of sources (federal, provincial, municipal governments and some private sector support), but the primary funder throughout this period was the thenDepartment of the Secretary of State (SOS) which provided project funding for specific demonstration or development projects. As a pan-Canadian organization, CAILC relied heavily on the organizational support of COPOI-I which provided office space and staff in Winnipeg. In November of 1988, however, the Honourable Jake Epp, then Minister of National Health and Welfare (NHW) under the Mulroney Conservatives announced the establishment of a pilot program, unlike any previously established by the federal state, which would establish a funding 'partnership' between the SOS, National Health and Welfare (NHW) and CAILC.2n This partnership (known as the Special Initiative) ensured a stable funding base (for a majority of the ILRCs) for five fiscal years extending from $1988 / 89$ to $1992 / 93$. With funding secured, CAILC's office moved from Winnipeg to Ottawa and five staff members were hired. 27 In September of 1991, the initiative was extended until March 31, 1996 when the federal state will have provided close to \$14 million in support for Independent Living in Canada. Finally, in February of 1996, the federal government extended core funding to CAILC and selected ILRCs until March 31, 1997.

Currently, CAILC derives its membership from 22 ILRCs which are controlled by autonomous boards of directors comprised by a maiority (at least $51 \%$ ) of persons with disabilities (See Table 6). Establishing the exact number of individuals the IL movement supports is difficult to discern because 
uniform statistics have never been collected by either CAILC or a majority of the ILRCs.

\section{TABLE 6}

Members of the Canadian Association of Independent Living Centres (1995)

\begin{tabular}{|c|c|c|c|}
\hline Province & $\begin{array}{l}\text { Date of } \\
\text { Incorporation }\end{array}$ & $\begin{array}{c}\text { Date of } \\
\text { CAILC } \\
\text { Membership }\end{array}$ & Organization \\
\hline British Columbia & 1990 & 1991 & Nanaimo and Region ILRC (Nanaimo) \\
\hline British Columbia & 1990 & 1992 & Cowichan Valley ILRC (Duncan) \\
\hline British Columbia & 1993 & 1991 & $B C$ interior ILRC (Vernon) \\
\hline British Columbia & 1990 & 1993 & South Vancouver Island RCIL (Victoria) \\
\hline Alberta & 1984 & 1985 & ILRC of Calgary (Calgary) \\
\hline Saskatchewan & $n / a$ & 1993 & Nurlh Saskalchewan ILRC (Saskaloon) \\
\hline Saskatchewan & 1991 & 1992 & $\begin{array}{l}\text { South Saskatchewan ILRC (Regina) } \\
\text { Independent Living Resource Cenlre }\end{array}$ \\
\hline Manitoba & 1985 & 1988 & (Winnipeg) \\
\hline Ontario & 1987 & 1987 & Independent Living Centre (Thunder Bay) \\
\hline Ontario & 1982 & 1987 & ILC of Waterloo Region (Kitchener) \\
\hline Ontario & 1987 & 1993 & Breaking Down Barriers (Collingwood) \\
\hline Onlario & 1978 & 1994 & $\begin{array}{l}\text { Kapuskasing Regional RCIL } \\
\text { (Kapuskasing) }\end{array}$ \\
\hline Ontario & 1989 & 1989 & Niagara CIL (St. Catherines) \\
\hline Ontario & 1985 & 1985 & CIL in Toronlo (Toronlo) \\
\hline Ontario & 1988 & 1988 & Kingston ILRC (Kingston) \\
\hline Ontario & 1989 & 1987 & Ottawa-Carleton ILC (Ottawa) \\
\hline Ontario & 1994 & 1995 & $\begin{array}{l}\text { ILRC-London(London) } \\
\text { Club des personnes handicapées de Val }\end{array}$ \\
\hline Québec & 1992 & 1991 & $\begin{array}{l}\text { D'Or (Val D'Or) } \\
\text { Centre de vie autonome Région du Bas St- }\end{array}$ \\
\hline Québec & 1987 & 1987 & $\begin{array}{l}\text { Laurent (Trois-Pistoles) } \\
\text { L'Association des personnes handicapées }\end{array}$ \\
\hline New Brunswick & 1981 & 1991 & de la Péninsule acadienne (Caraquet) \\
\hline Nova Scotia & 1989 & 1993 & Metro Resource CIL (Halifax) \\
\hline Prince Edward Island & 1993 & 1993 & $\begin{array}{l}\text { Prince Edward Island ILRC } \\
\text { (Charlottetown) }\end{array}$ \\
\hline
\end{tabular}

Source: CAILC, National Directory of ILRCs,(1995).

Aithough CAILC's role has evolved over time, it mainly provides support to its members ILRCs and represents Independent Living at the federal level. CAILC's supportive activities include: (1) promoting the development of ILRCs in communities; (2) articulating the IL philosophy in federal arenas; (3) providing organizational assistance, training and the 
implementation of programs to ILRCs; and (4) acting as a liaison between local ILRCs and various federal government departments.

The Canadian disability movement developed in two distinct stages; the disability consumer movement which emerged in the 1970s to contest the constrained position of PWDs collectively vis-à-vis the welfare state, and the Independent Living movement, which emerged in the 1980s to offer PIDs an alternative service delivery system defined by the principles of individual independence, self-sufficiency and integration into communities. As Sandra Carpenter, an early organizer of the Canadian Independent Living movement, explains:

The consumer movement [emerged] to take political action for social and substantive change on a general level...it is their job to...[put] pressure on the government. Of the independent living movement, the independent living centre's job is there primarily to help individuals with their circumstances (Canada, Standing Committee on Human Rights and the Status of Disabled Persons, Minutes, September 28, 1990: 37).

The focus of the Independent Living movement is on individual choice and control over personal resources, while the consumer movement involves itself in collective responses to group oppression through legislation, policy, atiitudes and so on. Independent Living in Canada does not have the antistate orientation which, as I discuss in the next section, is characteristic of the U.S. movement, reflecting its origins in U.S. 'New Left thought'.

Canadian disability movements are not counter-hegemonic in orientation partly because they require the provision of state supports and services for their existence and partly because Canadian political culture was defined by "radical liberalism" (Vickers, 1992). Certainly these movements assume a radical stance in their challenge to medical and social service institutions. In short, both the Canadian consumer disability and 
Independent Living movements are, as Gadacz suggests, "institutional reform movements" (1994: 129). In the following section, I focus on the U.S. disability movement, paying particular attention to its primary orientation as an individual rights-based or civil rights movement.

\section{III}

\section{Historical Overview of Disability Organizing in the United States}

The disability movement in the U.S. evolved differently than in Canada. Although both movements emerged at about the same time, in the early-1970s, the U.S. disability movement did not develop in two distinct wings with both a disability consumer movement and a Independent Living movement. The Independent Living movement superseded U.S. consumer organizations. The important distinction to be made between the two movements is that in the U.S., disability organizing developed primarily through a Independent Living movement whereas in Canada it developed mainly through a consumer disability movement. In this section, therefore, I focus on the foundation of the Independent Living movement in the U.S. examining the impetus for its formation and the kind of relationship the movement developed with the federal state. Although the IL movement was created by individuals operating at the grassroots level, it is clear that the 1973 Rehabilitation Act and the 1978 amendments to the Rehabilitation Act also played an important role in the development of the movement.

\section{Disability Organizing before the 1960s}

Prior to the 1960s, disability organizing in the U.S. was similar to the same time period in Canada. There is a long history of the formation of disability-specific organizations for PWDs by 'professionals', mostly able- 
bodied and parents (See Table 7). As Richard Scotch observes in his book on the U.S. disability movement and federal disability policy, "[m]any groups were dominated by able-bodied civic leaders or by service providers, and such organizations frequently operated on the basis of stereotypes of dependenc: for the disabled people they sought to represent" (1984: 33). "Two powerful examples of these organizations are the Disabled American Veterans (DAV), founded in 1920 by World War I veterans, but the organization was not run by them, and the American Foundation for the Blind (AFB), founded in 1921.28

\section{TABLE 7}

Organizations Representing Persons with Disabilities in the United States (Pre-1960)

\begin{tabular}{ll}
\hline Date Founded & Organization \\
1880 & National Association of the Deaf \\
1920 & Disabled American Veterans \\
1921 & American Federation for the Blind \\
1921 & American Foundation for the Blind \\
1925 & National Rehabilitation Association \\
1947 & Paralyzed Veterans of America \\
1948 & United Cerebral Palsy Association
\end{tabular}

Source: Scotch, (1984): 33-34, and original research.

The DAV is still in existence and characterizes itself as the "official voice of the disabled veterans" (Scotch, 1984: 33) with some 700,000 members, most of whom are Vietnam era veterans. Although they conduct federal lobbying on veterans affairs, their primary activity is counseling and advocacy for individual veterans. While the DAV has carried out an important role for disabled veterans, Scotch contends that "[t]he DAV has not been a major participant in promoting more general programs for disabled people" (1984: 33). The AFB is also a disability specific organization founded to represent the specific interests of blind persons. Perhaps the first consumer-led disability 
organization in the U.S., which preceded the development of most organizations of PWDs, was the National Federation of the Blind (NFB) which was founded in the 1940s. Scotch suggest this group was the "first organization of disabled people with a strong civil rights orientation" (1984: 33). Unlike the AFB, the NFB was led by persons who were blind and was an important force in gaining the establishment of guide dog and cane laws in the United States (Scotch, 1984: 34).29

\section{Disability Organizing Post-1960}

Scotch argues that, except of the NFB, the emergence of disability organizations run by PWDs themselves "occurred in the wake of the widespread and highly visible social conflicts of the 1960s" (1984: 35). Indeed, the civil rights movement, the anti-war and student movements, and the reemergence of the women's movement meant that people with disabilities "came to see their disability in the same political sense" (Scotch, 1984: 35) as the individuals involved in these movements. There is evidence, as well, that a cross-fertilization of tactics occurred between, for example, the women's movement and the emerging U.S. disabled persons' movement (Scotch, 1984; Roberts, 1995).

The 'barrier-free movement' seems to be the first evidence of an organized national disability network advocating for an end to architectural barriers. DeJong has marked the movement's formation in 1958 by the thenPresident's Committee on Employment of the Handicapped and the Veterans Administration. Through existing structures such as the President's Committee on the Employment of the Handicapped (PCEH), ${ }^{30}$ people with disabilities began a process of national networking which ultimately led to the formation of advocacy-based disability organizations in the United States (See 
Table 8). In 1971, a disabled teacher formed Disabled in Action (DIA) to lobby the municipal government in New York City. By the spring of 1972, DIA had several chapters in cities across the country and some 1500 members. In 1972, a group of disabled students at the University of California-Berkeley known as the Rolling Quads established the Centre for Independent Living (CIL) in Berkeley. In 1975, the first national cross-disability organization formed as the American Coalition of Citizens with Disabilities (ACCD). ${ }^{31}$

\section{TABLE 8}

Advocacy-based Disability Organizations of Persons with Disabilities in the United States (post-1960)

\begin{tabular}{ll}
\hline Date Formed & Organization \\
1971 & Disabled in Action \\
1972 & Centre for Independent Living-Berkeley, California \\
1974 & Boston Centre for Independent Living \\
1975 & American Coalition of Citizens with Disabilities (ACCD) \\
1976 & Disabled Rights Centre \\
1982 & National Council on Independent Living (NCIL)
\end{tabular}

Source: Scotch, (1984); Dejong, (1979); and original research.

Although both the DIA and the ACCD were national advocacy-based disability organizations, they did not develop into the sizable network as developed by the Independent Living movement and later disbanded. In 1977, there were 25 Centres for Independent Living located across the United States. By 1995 that number had increased to 262 federally recognized CILs (Woodward, 1995). Assessing the percentage of PWDs involved in these organizations is difficult. Nevertheless, in 1985, The Disability Rag a grassroots disability monthly, found that $61 \%$ of the CIL's were consumercontrolled; that is PWDs make up more than half of the Boards of Directors (1985: 42). I will now turn to the development of the U.S. Independent Living movement. 


\section{The Rise of the U.S. Independent Living Movement}

In accounting for the success of IL we could hypothesize that because the U.S. state (unlike the Canadian state) did not provide comprehensive services to PWDs, with the exception of veterans, there was a window for other services and supports to emerge. In addition, the U.S. Independent Living movement, unlike IL in Canada, regularly engaged in collective advocacy at both the state and federal level, thus fulfilling both the roles of advocate and service provider. Although valid, these explanations lack the complexity involved in capturing all the factors at play where disability organizing is concerned. There are three elements I consider further below: the U.S. variant of 'New Left thought'; the U.S. campaign for civil and political rights; and the federal legislative process in the U.S.

Independent Living emerged in an environment shaped by U.S. 'New Left thought'32 Indeed, the first Centre for Independent Living was founded on a university campus at Berkeley, California. Sohnya Sayres et. al. (1984) suggest that Berkeley was the site for the development of a number of important, 'radical' movements in the United States. Both the anti-war and free speech movements, 33 for example, can trace their origins to the campus at Berkeley. In fact, some observers contend that Berkeley was the site for the development of U.S. 'New Left thought' (Sargent, 1977). U.S. 'New Left thought', generally, is premised on an uneven mix of Marxian socialism and anarchism. Its proponents of were mostly white men who advanced the idea that individuals were alienated from themselves, each other, their work, and their communities resulting in a lack of freedom to make decisions and inequality within larger systems of oppression. They emphasized: participatory democracy, equality, liberty and community. The ideas advanced by 'New Left thought' leaders were heavily criticized by U.S. 
feminists and black leaders who maintained it had sexist and racist overtones (Vickers, 1992). Most important for this discussion, however, is the understanding that U.S. 'New Left thought', unlike 'Old Left thought', in the U.S. was anti-state in its orientation.

The U.S. Independent Living model, as defined by the formation of new, community-based disability resource centres, does not differ significantly from other 'institutional' forms developed out of U.S. 'New Left thought'. The Free School movement, for example, advocated a situation in which students and teachers would be equal in the learning process. This movement, some argue, identified the weaknesses of the contemporary U.S. educational system and acted to reform or revolutionize it. ${ }^{34}$ Sargent suggests that "the most positive tactic...suggested by the [U.S.] New Left...[was] the development of alternative institutions or alternative structures to the old society that [acted] as a tactic of the struggle and an indication of the goal" (1972: 130). The activism of PWDs in the U.S. Independent Living movement targets the "development of alternative institutions."

In the United States, collective political action to gain individual rights and protection against discrimination has been a hallmark of the dominant political culture. The black civil rights movement, for instance, raised the collective consciousness of many black Americans arguing for desegregation and basic individual rights. This movement ultimately led to the passing of the Civil Rights Act of $1964.3^{35}$ With the passing of this Act (in particular Title Vl) the rights-based entitlements of individuals were firmly entrenched into U.S. political culture. Jerome Bickenbach contends that for PWDs in the United States, "[a]ctivism seems to have been responsible for considerable legislative activity..." (1993: 160). Indeed, federal legislative activity propelled the rights of PWDs, and later the Independent Living movement into the 
U.S. mainstream. When amendments to the Rehabilitation Act (the central piece of federal legislation affecting Americans with disabilities) were under consideration in the early 1970s, "the growing activism of people with disabilities made it inevitable that discrimination against them would be on the agenda" (Bickenbach, 1993: 164).36

After several attempts, 37 the Rehabilitation Act of 1973 was passed by the United States Congress. ${ }^{38}$ Important for individual PWDs was the inclusion of Section 504, which removed the 'training elements' of the legislation through vocational education and employment programs and instead established federal support for the 'basic rights' of persons with disabilities in all contexts. Richard Scotch's (1984) analysis the passing of Section 504, clearly details the parallels between this legislation and the antidiscrimination legislation of the Civil Rights Act of 1964. In fact, the language in Section 504 mirrored that of the civil rights anti-discrimination legislation: "No otherwise qualified handicapped individual in the United States...shall, solely by reason of his [sic] handicap, be excluded from the participation in, be denied the benefits of, or be subjected to discrimination under any program or activity receiving Federal financial assistance" (United States Congress. Public Law 93-122). 39

Legislative legitimacy for the U.S. Independent Living movement would come in 1978 with passage of amendments to the Rehabilitation Act of 1973. Title VII of the Rehabilitation, Comprehensive Services, and Development Disabilities Legislation (Public Law 95-602) established support for U.S. Independent Living centres through the extension of federal grants. DeLoach et. al. have described the 1978 amendments as making "a historic contribution to the IL movement...simply because funds made available through it have enabled every state to begin offering some type of IL services" 
(1983: 19). Similarly, Zola has argued that the amendments "helped to solidify a movement by creating and legitimating a cross-disease and crossdisability orientation and community" (1994: 57) (See Table 9).

TABLE 9

Central Pieces of U.S. 'Civil Rights' Legislation Affecting Persons with Disabilities

\begin{tabular}{lll}
\hline $\begin{array}{c}\text { Year } \\
1973\end{array}$ & \multicolumn{1}{c}{ Title of Law } \\
Rehabilitation Act & $\begin{array}{l}\text { Key Provisions } \\
\text { Section 504 prohibits discrimination against } \\
\text { persons with disabilities in programs, } \\
\text { services, and benefits that are federally } \\
\text { funded. } \\
\text { Establishes Independent Living as a priority } \\
\text { for state vocational rehabilitation programs } \\
\text { and provides federal funding for Independent }\end{array}$ \\
$1978 \quad \begin{array}{l}\text { Rehabilitation } \\
\text { Comprehensive Services and } \\
\text { Developmental Disability } \\
\text { Amendments } \\
\text { Americans with Disabilities } \\
\text { Act (ADA) }\end{array}$ & $\begin{array}{l}\text { Living Centres. } \\
\text { Prohibits discrimination against persons with } \\
\text { disabilities in the areas of employment, } \\
\text { transportation, public accommodation and } \\
\text { housing. }\end{array}$ \\
&
\end{tabular}

Source: Dejong, (1983); Bickenbach, (1993).

There is no doubt that the Americans with Disabilities Act (ADA), passed in 1990 by the U.S. Congress represented the final development in the civil rights approach for PWDs in the United States. Bickenbach observes that, "the [ADA] extends more or less the same protection against discriminatory treatment in employment, transportation, and public accommodation to people with disabilities as are already in place for women and racial minorities" (1993: 169). As well, the ADA is consistent with the strongly-held view in the United States that individual freedom from discrimination is consistent with a market based economy. To that end, the major purpose of the legislation was to extend the anti-discrimination provisions contained in Section 504 in the Rehabilitation Act of 1978 into the private sector and into State and local governments. 
In Canada, Independent Living has been advanced through administrative arrangements within the bureaucracy. The successes of the Independent Living movement in the United States, by contrast, were won through legislation passed by the Congress. The 1978 amendments to the Rehabilitation Act established ongoing, stable core funding for CIls in the United States. Indeed, in 1977, before the legislation was enacted there were 10 CILs in the United States, by 1983 there were 160 centres receiving Title VII funds and over 344 offering Independent Living programs (Disability Rag, 1985: 42).40 The central question is: Why has Independent Living received legislative support in the United States?

The idea of charity for PWDs has been pervasive in western society since the development of British Poor Laws in the fourteenth century. 41 In the United States, charity continues to figure prominently as a normative basis for the extension of entitlements of PWDs. Jerome Bickenbach observes that while the charity model is a weaker influence in the era of the welfare state, it nonetheless continues to be an important factor in disability policy (1993: 192-198). The charity model, briefly, is informed by Judeo-Christian traditions and largely is responsible for the development of charitable organizations in North America which many argue negatively impact social perceptions of disablement (Bickenbach, 1993; Oliver, 1990) Many of these organizations represent PWDs as 'dependents' which results in handicapping in centemporary society. As Bickenbach argues, "charity is a virtue that enhances the moral status of the giver, since he or she has benefited another without having the duty to do so" resulting in "the charitable [being] enriched more than those who receive the charity" (1993: 195).

Although Bickenbach suggests that the charity model has been superseded by theories of the welfare state, in the United States, where 
support for the welfare state has been weaker than in Canada, charity remains an important factor understandings of disablement. In contemporary society, the television telethon is the cadillac of charity giving. The annual Jerry Lewis Telethon for the Muscular Dystrophy Association (MDA) is perhaps the most famous (Guly, 1993). Labour Day weekend, in North America, has become synonymous with the Jerry Lewis Telethon which purports to collect funds to find a 'cure' for muscular dystrophy. In 1992, for instance, the muscular dystrophy telethon raised $\$ 45.8$ million in viewer pledges (Nelson, 1994: 5).42 As one disability activists asserts, however, "[f]or disabled people, telethons are the embodiment of a malignant benign oppression: fundraising, supposedly for a good cause, conducted at the expense of the dignity and integrity of its intended beneficiaries" (Bolt, 1995: 24). In the charity model PWDs are not viewed as social-political actors, but as victims of a tragic fate deserving of pity or as damaged people who can be 'cured'.

The Independent Living movement rejects the charity model of disablement and instead advances the very American goal that PWDs should reclaim their own lives by asserting their autonomy in opposition to statecontrolled monopolies. The movement advocates a radical individualism characterized by a 'macho', male-centric orientation which rejects dependency. This goal is achieved, as DeJong suggests, through an attachment to the rational and competitive pursuit of personal interests in the political and economic market place (1979: 5-7). As Gareth Williams argues, although the U.S. IL movement is "radical" to the extent that it advances "consumer sovereignty, self-reliance and political and economic rights for persons with disabilities," it nonetheless involves "a basic commitment to the American capitalist system with its free-market pluralist ideology" (1983: 1004). 
Given these factors, the appeal of IL for U.S. politicians and bureaucrats is clear. The issue for PWDs as framed by the IL movement is independence. The issue for governments is ending dependence on state-funded welfare programs. Funding the Independent Living movement permits the further decentralization of state-sanctioned programs for persons with disabilities. In short, the U.S. commitment to Independent Living represents a acceptance of individual civil rights and a market-based 'purchase' orientation of disabilityrelated services, as opposed to social justice for all persons with disabilities achieved through state-funded programs (Williams, 1983).

As I discuss in the next section, the U.S. Independent Living movement had broad appeal to the already established Canadian disability consumer movement and to the Canadian federal government. I focus on the way in which Independent Living was transplanted from the United States into Canada. As well, I pay particular attention to how IL changed once faced with "Canadian realities."

\section{IV}

\section{The Same; but Different:}

\section{Transplanting the U.S. IL Movement into Canadian Disability Organizing}

Diane Driedger argues that the Canadian disability consumer movement "sprang up independently of that in the United States" demonstrating that "there was no contact between U.S. and Canadian disabled people's groups" (1989: 22). A significantly different pattern emerged in the 1980s, however, as international influences affected both the Canadian disability movement and Canadian disability policy at the federal level (Prince, 1992). The influence of the U.S. Independent Living movement on 
both the Canadian disability consumer movement and the federal state is part of this pattern.

\section{Planting the Seed: The Beginnings of Independent Living in Canada}

The first evidence of the idea of Independent Living being discussed in Canada is during the 1979 hearing for the federal Canadian Transport Commission. Henry Enns, a long-time Canadian disability activist involved with COPOH, while on his way to the conference in Ottawa, read an academic paper by Gerben DeJong, an able-bodied U.S. public policy scholar, who (in 1979) had published one of the first academic papers on the U.S. Independent Living movement. ${ }^{43}$ Once in Ottawa, Mr. Enns consulted with Allan Simpson and Jim Derken, also from $\mathrm{COPOH}$, on the applicability of IL to Canada. They concluded, collectively, that Independent Living should be placed on the agenda for a larger discussion. ${ }^{44}$

Although these discussions were the first to be held on IL in Canada, as I noted above, formal introduction of the idea of Independent Living came at COPOH's Third National Conference--Defining the Parameters of Rehabilitation held in Vancouver, British Columbia in 1980. Gerben DeJong was invited by $\mathrm{COPOH}$ to attend the conference and speak to delegates concerning Independent Living in the United States. Members of the Canadian disability movement seem to agree that DeJong, in making his presentation to the delegates at the conference, significantly influenced the formation of a link between the already established Canadian disability consumer movement and the IL philosophy of independence and integration. Driedger and D'Aubin suggest, for example that "Independent Living, both as a philosophy and service delivery model, was a logical progression for the persons with disabilities movement in Canada" (1985: 14). 
In their study of cross-national movement diffusion, McAdam and Rucht argue that the formation of "relational bridges" between movement types is influential in communicating ideologies, tactics, and organizations structures from one movement to another (1992: 62). Although their analysis centres on the civil rights and women's movements in the United States, I think it is fair to hypothesize that the explosion of movement activity during the 1970s and 1980s in North America influenced Canadians with disabilities to re-examine their position within Canadian society. McAdam and Rucht's theoretical model is premised on "relational" and "nonrelational" models of diffusion which occur between national movements. Relational diffusion involves direct, interpersonal contact between members of movements, while nonrelational diffusion occurs in a more subtle fashion such as through the influence of the mass media. The diffusion process results, McAdam and Rucht maintain, in "heterogeneous populations such as college students, environmentalists, or feminists may come to regard their counterparts in other countries as salient reference groups" (1992: 64). They conclude:

[T] he tendency of movements to cluster in time and space suggests...that while the development of insurgency is expected to be profoundly shaped by the unique political and cultural context in which it is embedded, it is quite likely that the initial impetus or inspiration for the movement may be imported from elsewhere (1992: 65).

Indeed, Independent Living has emerged in numerous countries around the world including: Britain, Sweden, Denmark, England, Australia and Japan (Tate et. al., 1979; Oliver, 1990). My discussion now turns to a discussion of how Independent Living, once transplanted to Canada, was shaped by the unique political and cultural context of "Canadian realities." 


\section{Establishing the Differences: IL in Canada versus IL in the United States}

The scarce available literature on the Canadian IL movement points to its origins in the United States. Certainly, the introduction of the Independent Living concept by Gerben DeJong at the Defining the Parameters of Rehabilitation conference set into motion a series of events which ultimately led to the formation of Independent Living organizations in Canada. Nevertheless, despite obvious similarities between the Canadian movement and its U.S. counterpart, there are important differences as well. There are three main differences on which I focus below: each movement's formative influences; their respective orientations to the federal state; and their respective relationships with their respective federal government's.

Formative Influences: The formative influences of the U.S. and Canadian Independent Living movement were significantly different. While it is the case that the Canadian disability consumer movement and the U.S. Independent Living movement emerged during similar historical periods, the Canadian IL movement developed more than a decade after IL in the United States. As a result, the momentum behind each movement was different. The U.S. Independent Living movement developed out of its civil and political rights tradition and was a product of U.S. 'New Left thought'. At Berkeley, Independent Living established itself as profoundly anti-state and anti-professional in its orientation. It sought to establish new communitybased disability resource centres which would act as a counter-institution and an alternative service-delivery model replacing the medical/rehabilitation model. Finally, the U.S. IL movement, as part of the white, young male 'New Left' reaction to the black civil rights approach did not deal well with issues of race or gender, especially with its emphasis on 'rugged individualism'. In 
1992, Ed Roberts, one of the founders of IL in the United States, argued that "CILs don't do enough reaching out to Asian, African, [and] Hispanic communities...When you look at many CILs you see white middle class" (1995: 11).

Independent Living in Canada was transplanted from the U.S. model, but was fostered by the pre-existing disability consumer movement and developed through administrative arrangements within the federal bureaucracy. It was individual activists involved in COPOH who pushed to get Independent Living on the national agenda. While the U.S. movement was influenced by the civil and political rights tradition, the Canadian IL movement can trace some of its earliest influences to the long-held social gospel tradition in Canada.45 A number of Canada feminist, environmental and peace organizations can trace important support to religious organizations. The Canadian peace movement, for instance, has strong connections to the United Church of Canada.46 Independent Living in Canada initially found support in the Mennonite Central Committee (MCC). In particular was Henry Enns' active involvement with the MCC (Valentine, 1994).

Enns' role in educating professionals, politicians, and people involved in the MCC ensured that the Independent Living model was not ignored. His early consultant role with the Handicapped Concerns Program of the MCC provided him with the opportunity to travel across the country and raise awareness about $\mathrm{I}$ and disability issues to a large cross-section of Canadian society (Vailentine, 1994: 18-19). Jake Epp, the Minister of Health and Welfare was also a Mennonite and knew Henry Enns through their association with the MCC. The Ontario branch of the MCC was the first to lend support to Independent Living which should come as no surprise given its nature as a 
service organization from a church base with a long commitment to self-help and social justice issues. In fact, the MCC supported the establishment of the first ILRC in Canada. Under the guidance of the MCC in Ontario, a feasibility study was conducted in Waterloo. Public education and increased awareness of the needs of persons with disabilities were also undertaken in that community. Funding for the Centre was secured through the MCC (Ontario) and some funding from the provincial government. Shortly thereafter the Independent Living Centre of Waterloo Region opened with Mir. Enns as the first executive director. ${ }^{47}$

As in the U.S., disability organizing in Canada evoived with its core constituency mainly involving young white males. Indeed, the Independent Living movement in the United States with its origins on university campuses was composed predominately of older adolescents and young working adults or students in their twenties with mobility impairments (DeJong, 1979: 435-6; Driedger, 1989: 22). The Canadian movement was founded on the principle of cross-disability and, therefore was (and is) more representative across disability and age lines. Nevertheless it received considerable criticism from women with disabilities who were influenced by a strong women's movement. In 1985, a feminist disability organization, the DisAbled Women's Network (DAWN) emerged, as Joanne Doucette, a disabled feminist argues, because "it [was] men who [were] by and large, in decision-making positions within the disabled consumer movement...[and disabled women] had enough of being ignored, patronized and placated" (1991: 222). Women have made considerable advances within the Canadian disability movement, but many still argue they are marginalized within the movement and therefore "doubly disadvantaged" in Canadian society.48 It has been only very recently that the Canadian disability movement has begun 
to address the issue of race and minority cultures as they affect people with disabilities. In Ontario, for example, the Coalition of Ethno-cultural People with Disabilities emerged in 1993, but is still in its infancy. Like the women's movement before it, the Canadian disability movement has begun the difficult and complex process of addressing these issues within its constituency.

Orientation towards the State: As I suggest above, the U.S. Independent Living movement derives its anti-state orientation from U.S. 'New Left thought'. The Canadian IL movement, by contrast, has never had this antistate orientation. The reason perhaps is that the 'New Left' in Canada was mainly state-focused and this orientation has been a central element of movement organizing in Canada. Discussing the intellectual origins of the English-Canadian women's movement, which is now over a century oid, Jill Vickers suggests its operational code for "doing politics" has been characterized by "radical liberalism" (1992: 40). Vickers argues that radical liberalism reflects the pervasiveness of Canada's general political culture and embodies

a commitment to the ordinary political process, a belief in the welfare state, a belief in the efficacy of state action in general to remedy injustices, a belief that change is possible, a belief that dialogue is useful and may help to promote change, and a belief that service in terms of helping others is a valid contribution to the process of change (1992: 40).

Research shows there were important early influences of the EnglishCanadian women's movement on disability organizing (Driedger, 1989; Enns, 1981).

Given that the welfare state in Canada was more developed than in the United States, it is not surprising to discover that the Independent Living 
movement has been state-centric in two important ways: it relies heavily on federal and provincial governments for organizational funding and views government as the best recourse in society to effect chance for PWDs. This is particularly clear if we examine the 'advocacy role' which the Standing Committee on Human Rights and the Status of Disabled Persons has played at the federal level on behalf of Canadians with disabilities. Traci Walters, the national director of CAILC, describes the Committee "as catalysts of change for persons with disabilities throughout this country" (Canada, Standing Committee on Human Rights and the Status of Disabled Persons, Minutes, June 8, 1993: 102). Unlike the U.S. Congress, the Canadian Standing Committee assumes on-going responsibility for disability issues.

The Canadian Independent Living movement is certainly more focused on government than its U.S. counterpart, as I will show in chapter three. Pal suggests, in his study of state funding to the voluntary sector that, during the late-1960s, the SOS had a mandate from the Liberal government to "force the pace of citizens' participation" (1993: 268) which resulted in the Canadian government's conceptual understanding of the voluntary sector changing dramatically from "classical liberal principles that had always kept some distance between government and organizations" towards "a more 'proactive' stance" (Pal, 1993: 269). Indeed, this parallels Vickers observation that movements were defined by radical liberalism. This proactive stance resulted in many organizations receiving funding from the federal state including: women's, multicultural, official language minority, gay/lesbian and disability groups. Unlike the U.S. Independent Living movement, which was funded through mechanisms built into the rehabilitation legislation and premised on the notion of individual civil rights, the Canadian $\Pi \mathrm{L}$ movement organizations received funding through the government programs premised 
on a radical liberal concept of activist citizenship, developed through a facilitator state (Pal, 1993).

Relationship with the Federal Government: In the United States, the Independent Living movement has developed a relationship with the federal government largely through legislative acts of Congress. Indeed, the 1978 amendments to the Rehabilitation Act established core funding for CILs across the country. In Canada, however, the movement's relationship to the federal government has been through administrative arrangements rather than legislation.

It is important to note that the political and legal traditions of Canada and the United States are also different which affects the way in which each country characterizes antidiscrimination provisions. Although contemporary governments eventually may create a somewhat different pattern, I believe that Bickenbach is correct when he asserts that Canada has "far less ideological objection to more direct and affirmative social responses to systemic discrimination" (1993: 170-1). Certainly the Charter supports this stance. The U.S. political and legal system makes it possible for Congress to pass legislation as far reaching as the Americans with Disabilities Act. Equally important to note, however, is the possibility that the legislation can be repealed by Congress. In Canada, however, our "constitutional structure, and present uncertainties about the divisions of power between federal and provincial governments, make it dangerous to apply the American legal experiences here" (Bickenbach, 1993: 170). Instead, Canada has put in place a series of "conciliatory mechanisms of human rights codes" (Bickenbach, 1993: 170) and a constitutional guarantee of equality in the Canadian Charter of Rights and Freedoms, which unlike legislation, cannot be repealed. 
In Canada, most movement groups have a close relationship with the federal government. ${ }^{49}$ Even movement groups in Québec have tried to balance federal/Québec ties (Vickers, 1992). Susan Phillips argues that, in general, Canadian movements have "developed a closer relationship to the state than have their counterparts in many other countries" (1994: 199). Indeed, Vickers (1992) characterization of 'radical liberalism' as the "operational code" for English-Canadian women's movements “doing politics" in Canada has meant that movements hold, in part, a belief in both the welfare state and the efficacy of state action. 50 Given this orientation, it comes as no surprise that the federal government's provision of "substantial financial support to many movement organizations" (Phillips, 1994: 199) has been a hallmark of Canadian movement activity beginning in the $1960 \mathrm{~s}$.

The federal state, Phillips argues, has a role in fostering democracy and democratic institutions, thus state support for "less advantaged groups" who "cannot compete" with other individuals and groups "on an equal footing" has resulted in the state "enhancing Canadian democracy" (1994: 200). Commentators on the ideological left of movement politics, however, take issue with this argument and suggest that the federal government fostered relations with movement groups to de-radicalize and co-opt their activities (Findlay, 1987; Ng, 1988, Kinsman, 1992). Sue Findlay, for instance, in her examination of the relationship between the Canadian women's movement and the federal government from 1966 through 1980, argues that

in the process of integrating the status of women issue into the policy-making process, the state...significantly modified the radical implications of women's demands for equality by incorporating them into an equal opportunity framework and by limiting participation of representatives from the women's movement to token consultations (1987: 47-8). 
Leslie Pal explores the 'patronage' and 'co-optation' schools of thought, but argues that "cannot explain the full story" (1993: 122). He concludes that movement groups were not co-opted by the ferteral state and suggests instead that there was "political logic" behind these funding programs which are most fully explained as a "response to unrest, [aibeit] in a distinct manner" (1993: 121).

While no one argument can explain the complexity of state/civil society relations in contemporary society, these positions do provide a window of understanding into the myriad of forces which influenced the development of the disablement programs and policy at the federal level. Beginning in the late-1970s the SOS through its newly created 'Voluntary Action' division, which in 1985 became the Disabled Persons Participation Program (DPPP) ${ }^{51}$ provided sustaining support to disability organizations to foster their full participation as citizens in Canadian society. Funding for Independent Living, therefore, emerged out of an environment defined by radical liberal principles of citizenship participation unlike the American movement based in a rehabilitation framework modified by American values of individualism, independence and self-sufficiency.

\section{V}

\section{Conclusion}

The Canadian Independent Living movement has developed from within a political opportunity structure defined, as Robin Mathews argues by the tension of the "Canadian dialectic" (1988); that is, Canada's political culture cannot be defined exclusively by collectivism or individialism. Instead it is based on the tension between neo-liberalism and liberalism, in a 
Canadian identity which is "a matter of forces in tension...which often stalemate...and are forced to submit to compromise" (1988: 1).

Charles Taylor has made a significant contribution in advancing our understanding of how two major strains of liberal democracy address the "politics of recognition" in Canadian political discourse (1992). Taylor has outlined two basic understandings of liberal democracy which he, like Mathews, concludes are in constant interaction and tension. The first can be understood as the politics of equal dignity which emphasizes equal dignity for all citizens, with a strong commitment to individual rights before the state. As Taylor observes this type of liberalism is concerned with "...a politics of universalism, emphasizing the equal dignity of all citizens, and the content of this politics has been the equalization of rights and entitlements" (1992: 37). Indeed, as Michael Walzer observes, this first strand of liberalism places the state in a completely neutral position defending no particular cultural, religious and/or collective goals (1992: 99). Taylor also identifies the second kind of liberalism, however, the politics of difference, in which the state recognizes the distinctiveness of individuals and groups within society (1992: 38). Walzer characterizes this second strand of liberalism as committed "to the survival and flourishing of a particular nation, culture, or religion...so long as the basic rights of citizens who have different commitment or no such commitments at all are protected" (1992: 99).

The first strand of liberalism violates the principle of equality simply because it reflects a single hegemonic culture which Taylor states would flow of Rousseau's general will. Taylor asserts, that the second version of liberalism does not focus on the "rigidities of procedural liberalism" (1992: 61), but is willing to put collective cultural survival ahead of the rights of individuals when required. He states that this new model of liberalism is 
evolving not because of altruistic tendencies, but because as "more and more societies today are turning out to be multicultural...[t]he rigidities of procedural liberalism may rapidly become impractical in tomorrow's world" (1992: 61). In other words, identical treatment of individuals which creates a homogeneous society may no longer be a realistic project-particularly in Canada.

Taylor maintains that Canada has had both versions of liberalism confronting each other throughout its long and inconclusive constitutional debates (1992: 52). He states, and most would agree, that since 1982 when the Charter was adopted our political system has become more closely aligned with the U.S. system. It is the case that the Charter provides a basic set of rights to all individuals before the law which captures the essence of classical liberal-democracy. But the Charter also protects the rights of collectivities, including those of persons with physical and mental disabilities.

As I have shown in this chapter, this "tension in dialectic" between two strains of liberalism seem to have created an activist Canadian state in the 1970s and 1980s marked by radical liberalism which sought to advance the 'citizenship' and 'personhood' of disadvantaged individuals. In the 1990s, however, radical liberalism seems to have given way to a neo-liberal agenda of fiscal constraint and deficit reduction. As I discuss in chapter three, it remains to be seen if those active in movements for change generally will trade in their radical liberal values for a more disengaged oppositional stance as the state becomes less of an ally and recourse. For PWDs, however, the full emergence of citizenship rights required state support of their organizations in the consumer disability and the Independent Living movements. In a country as large, diverse and sparsely populated as Canada, it may simply not be possible for PWDs to organize 'nationally' without government support 
for their organizations. In short, some political citizenship for some groups requires on-going state support.

The Canadian Independent Living movement, both as a political strategy and an organization model, was 'invented' in the United States. In less than a decade, it was transplanted into Canada. Many individuals assume that given the Canadian movement's transplanted origins, it is similar to its U.S. counterpart. In this chapter, I demonstrated that is not the case. Through an analysis premised on the understanding that the political environments in which movements develop profoundly affects their representation project (Rankin, 1995), I have sought to uncover the macrocauses of the differences between the Canadian Independent Living movement and the U.S. counterpart from which it was born.

In the next chapter, I present empirical evidence concerning the Canadian Independent Living movement at the federal level. My aim is further to explore the unique character of the Canadian Independent Living movement and in so doing track its relationship vis-à-vis federal state machinery. 


\section{NOTES}

${ }^{1}$ My treatment of this argument has been influenced by the work of Vickers, Rankin \& Appelle in which they argue that "[w]omen's movements are profoundly affected by the political culture in which they develop and by the nature of the state regime during key periods of their development. See, Vickers, et. al., (1993: 8).

${ }^{2}$ For a complete discussion on the Canadian eugenics movement, see, Angus McLaren, Our Own Master Race: Eugenics in Canada, 1885-1945 (Toronto: McClellend \& Stewart, 1990).

${ }^{3}$ An important consideration which is often overlooked was the role that persons with disabilities played in domestic industries during the Second World War. Massive mobilization and enlistment resulted in domestic industries having to employ persons with disabilities in a variety of job categories. This period is significant because it represents the only time, in recent history, that equality of employment opportunities were extended to people with disabilities. After the war, however, persons with disabilities were relieved of their jobs and the positions were filled with non-disabled individuals. See, Frank Bowe, Handicapping America (New York: Harper and Rowe, 1978).

${ }^{4}$ The March of Dimes can trace its origins to a fundraising campaign held in the late-1930s to raise funds for children with paralytic polio. Mass support for the organization was assisted when President Roosevelt contracted paralytic polio. In the 1940s, an Ontario organization called "Marching Mothers" held fundraising campaigns for polio research and sent their efforts to the United States. In 1951, however, this organization changed its name to the Canadian Foundation for Poliomyelitis, iater known as the Ontario March of Dimes.

${ }^{5}$ As I discuss later in this chapter, parallel single-disability organizations in the United States include, for example, the Disabled American Veterans (founded 1921) and the National Federation of the Blind (founded 1940). For more information on the development of these organizations, see, Scotch (1984): 32-34.

${ }^{6}$ As I discussed in chapter one, from the 1950s through to the 1970s, the federal government began to assume much greater responsibility for social services, health and educalion (through cost-sharing) over the provinces and local level. This made the development of pan-Canadian organizations necessary.

${ }^{7}$ The available research on the early development of the Canadian consumer disability movement is scarce. Nevertheless, I am indebted to Diane Driedger for providing me with a copy of an unpublished manuscript she researched and wrote detailing the early history of the movement ivithout this research, this study would have been incomplete.

8This is unlike the pan-Canadian women's movement which has mostly been focused at the federal level because most things women's organizing wanted (abortion, legal equality) were federal, rather than provincial responsibilities.

${ }^{9}$ Two other provincial consumer disability organizations emerged in the early 1980s. They include: the Consumer Organization of the Disabled of Newfoundland and Labrador in 1980 and the Mouvement des Consommateurs Handicapés du Québec in 1982.

${ }^{10} \mathrm{COPOH}$ did not have any consumer disability organizations as members from either of the territories. 
${ }^{11}$ Action taken by PWDs during the 1979 Transportation Conference resulted in the architectural accessibility to the Parliament Buildings. After the conference (on November 26th), a group of PWDs who were wheelchair-users from British Columbia decided to observe the Commons in session on invitation from their MP, New Democrat Ian Waddell. They were unable to get into the Buildings, however, and ultimately had to use a freight entrance. As well, all elevators in the Buildings were inaccessible and a group of Mis had to carry the wheelchair users up the stairs. lan Waddell introduced a motion, which was agreed to unanimously by all parties, that the Parliament Buildings had to be made accessible for PWDs. See, Canada, House of Commons, Hansard November 26, 1979: 1676. The Obstacles report (1981a) also contained a recommendation on the physically accessibility of the Parliament Buildings.

${ }^{12}$ It is important to note that the province of Québec proclaimed its Charter of Human Rights and Freedoms in 1981 which provides for a full and equal recognition and exercise of rights "without distinction, exclusion or preference based on disability or the use of any means to palliate a handicap" (Chapter I. 1 [10]). As well, an important consideration is that the equality provisions (s. 15) of the Charter did not come into effect until April of 1985.

${ }^{13}$ This Committee was the central governmental body considering Section 15 of the Charter of Rights and Freedoms.

${ }^{14} \mathrm{An}$ umbrella organization is best understood as a group which brings together a "coalition of groups of different sizes, ages and structures for a political or other purpose" (Vickers, Rankin \& A ppelle, 1993: 328). The organization, therefore, is not comprised of individual members, but rather forms its membership from community-based, regional groups in which individuals have local membership.

${ }^{15}$ Francine Arseneault, chair of $C C D$, explained the organizational name change in the following manner: "We have changed our name to the Council of Canadians with Disabilities because our membership and our mandate have broadened. We originally represented provincial organizations, but there was such a demand for more participation from nationa! organizations and other regional and local organizations that we broadened our mandate to cover issues that affect all of them and reach the federal level." See Canada, Standing Committee on Human Rights and the Status of Disabled Persons, Minutes, (May 24, 1994): 5.

${ }^{16}$ To date, CCD does not have any associate members.

${ }^{17} \mathrm{~A}$ cross-disability framework recognizes that people with different disabilities have different needs, and therefore, ensures that programs and resources are accessible to persons with varied types of disabilities. This notion represents a departure from traditional approaches to disability in which the needs of a specific disability type (i.e., individuals with physical disabilities) were met while other types of disability were ignored.

${ }^{18}$ The concept of normalization originated in Denmark in 1959 by a medical doctor working with cognitively disabled individuals. The concept picked up momentum and was tested in the United States during the late-1960s. For a more comprehensive discussion on the origins of the normalization movement and its impact in Canada, see Kallen, (1989: 159-166).

${ }^{19}$ See Appendix A for a flow chart detailing how the IL core programs integrate with the idea of Independent Living. 
${ }^{20} \mathrm{As}$ I suggest later in this chapter, the anti-state orientation of the New Left in the United States, was not a major feature of the Canadian New Left.

${ }^{21}$ Gareth Williams critiques DeJong's assessment of the U.S. Independent Living movement arguing that it offers only a partial view of disablement. Williams notes that Dejong neither take class nor race into consideration when he constructs his free-market/pluralist model in which everyone is equal and can challenge the system through common market values. See, Gareth Williams, "The Movement for Independent Living: An Evaluation and Critique," Social Science and Medicine, 17, 15 (1983): 1003-1010.

${ }^{22}$ For a complete list of the Standing Committee and its predecessors reports, see Chapter three.

23 See Canada, Special Committee on the Disabled and the Handicapped, Obstacles, (Ollawa: Supply and Services Canada, 1981).

${ }^{24}$ Personal communication, October 19, 1995.

25Personal communication, February 21, 1996.

${ }^{26}$ In October of 1993, a governmental re-organization occurred under the Chretien Liberal government. As a result, the Secretary of State and the Department of Health and Welfare were merged with the Departments of Labour and Employment and Immigration Canada to form a 'super-department' known as Humar, Resources and Development Canada (HRDC.). Given this reorganization, the partners of the Special Initiative are now CAILC and HRDC.

${ }^{27}$ CAILC's first National Director was Ross Robinson. Other staff positions included: an organizational development office, a financial resource consultant, a bilingual administrative support person and a researcher.

${ }^{28}$ The AFB was founded when the American Association for Workers for the Blind and the American Association of Instructors of the Blind merged in 1921.

${ }^{29}$ The NFB's founder and president for over two decades was Jacobus tenBroek, a blind lawyer.

$3^{30}$ The PCEH was founded after World War II to promote the employment of disabled veterans in the United States. Although it was dominated by professionals, Scotch (1988) has argued this Committee did attract young 'militant' disabled activists which led, ultimately, to "strengthening personal and organizational ties among disabled activists" (165).

${ }^{31}$ For more information of the early activities of disability organizing in the United Slates, see, Rita A. Varela, "Organizing Disabled People for Action." Nancy M. Crewe and Irving Kenneth Zola (eds), Independent Living for Physically Disabled People (San Francisco: JosseyBass Publishers, 1983).

${ }^{32}$ As I expand upon below, Jill Vickers suggests that New Left though in Canada was different than in the United States. In particular, the New Left in Canada was pro-statist. See, Vickers, (1992).

${ }^{33}$ The free speech movement emerged at Berkeley out of the influence of the civil rights movement. It was organized to put pressure on the University administration to have the restrictions removed against students' disallowing them to propagandize their political views 
on campus. Eventually, this movement spilled beyond the boundaries of the University at spread to form regional and national organizations. For more information see, Sargent, (1972): 9-15; Sayres et. al., (1984).

${ }^{34}$ For more information of the American free school movement see, for example, Staughton Lynd, "The Freedom Schools: Concept and Organization," in The New Left: A Documented History, Massimo Teodori (ed), Indianapolis: The Bobbs-Merrill Co, 1969.

${ }^{35}$ The Civil Rights Act of 1964 prevented discrimination of any recipient of federal funds on the basis of race, colour, or national origin. This formula acted as a model for antidiscrimination legislation throughout the United States.

${ }^{36}$ For a more detailed account of the way in which the civil rights models, and in particular Title VI of the Civil Rights Act affected the movement of persons with disabilities in the United States, see Scotch, (1984): 24-27.

37The legislation was initially passed in Congress in 1972, included an attempt to deinstitutionalize people with disabilities through Independent Living provisions. President Nixon, however, vetoed the legislation at two different times arguing that it "strayed too far from the essential vocational objectives of the [vocational rehabilitation] program." See, DeLoach, et. al., (1983): 17; and Scotch, (1984): 54-58.

38 The Rehabilitation Act of 1973 has its origins in legislation dating as far back as the 1920 s. For an historical overview of the federal legislation affecting persons with disabilities in the United States, see Gerben DeJong, "Physical Disability and Public Policy," Scientific American, 6, 248 (1983): 40-49.

${ }^{39}$ For a more detailed discussion on the passing of this legislation, see, DeLoach, et. al. (1983): 17-24; and Scotch (1984).

$40 \mathrm{It}$ is important to note that systematic research on the overall impact of the American IL movement is scarce. The Research and Training Centre on Independent Living operating under a National Institute of Handicapped Research conducted a study of CILs in the United States. They found discontinuity concerning the meaning of IL programs and services and found that the biggest barrier for a majority of Centres was changing the perception of people with disabilities within their communities. For more information of this study, see The Disability $\underline{\operatorname{Rag}}$ (September, 1985): 42.

41 'English Poor Lawos drew distinctions between the 'worthy' and the 'unworthy' poor based on economic and social roles. It set out a difference among those who could were unemployed, yet were able-bodied and could therefore be made to work and those who were consider disabled and therefore allowed to beg. An important historical consideration, however, is the rejection of British Poor Lawes in Upper Canada during its first session in 1792. Richard Splane, in his text on social welfare in Ontario from 1791-1893, suggests that it was rejected because the new colony "manifestly lacked the ability to undertake the responsibilities associated with English-type poor law" (1965: 66), specifically the well-defined social roles necessary. See, Richard Splane, Social Welfare in Ontario, 1971-1893, (Toronto: University of Toronto Press, 1965).

42 Other major charitable organizations in the United States include: the Special Olympics and the Shriners Hospitals for Crippled Children. 
${ }^{4.3}$ See DeJong, (1979).

${ }^{44}$ Personal Communication, October 19, 1995.

${ }^{45}$ This finding supports the work of Richard Allen on the social gospel in Canada. See, Richard Allen, The Social Passion: Religion and Social Reform in Canada, 1914-28 (Toronto: University of Toronto Press, 1973).

${ }^{46}$ For a comprehensive analysis of the United Church and the Canadian peace movement, see, Shiriey Farlinger, A Million for Peace: The Story of the Peacemaking Fund of the United Church of Canada, (Etobicoke: The United Church Publishing House, 1995).

${ }^{47} \mathrm{Enns}^{\prime}$ is a PWD and has since served as chair on CAILC's Board of Directors and currently, remains a member of the Board. As well, he has been instrumental in the development of Disabled Persons' International (DPI). DPI was founded in 1981 and is comprised of groups in over 100 member countries. This organization recognizes the potential benefits of combining experiences, technical and financial resources in responding to the needs of persons with disabilities around the world. See, Driedger, (1989).

${ }^{48}$ For more information on the development of DAWN and the way in which it relates to the larger Canadian disability movement see, Diane Driedger, "Discovering Disabled Women's History" In And Still We Rise: Feminist Political Organizing in Contemporary Canada. Linda Carty (ed), (Toronto: Women's Press, 1993); Joanne Doucette, "The DisAbled Women's Network: A Fragile Success," In Women and Social Change: Feminist Activism in Canada, Jeri Dawn Wine and Janice L. Ristock (eds), (Toronto: Lorimer, 1991). On feminism and disability generally, see, Jenny Morris "Feminism and Disability," Feminist Review 43 (Spring, 1993): 5770. For an international perspective on women with disabilities, see, Diane Driedger and Susan Grey (eds), Imprinting Our Image.,(Charlottetown: Gynergy Books, 1992).

${ }^{49}$ It is important to note, however, that prior to the $1960 \mathrm{~s}$, it was local governments, not federal and provincial powers who were responsible for social welfare. As Shlomo Hasson and David Ley (1993) detail in their comparative investigation of local groups in Vancouver and Jerusalem, it was not until the 1930s that "senior levels of government assume[d] a greater share of the cost of health and social services" (25). Christine Ball's (1994) research on the Voice of Women (VOW), for example, has shown that the VOW received financial support from the City of Toronto as late as 1961. See, Christine Ball, "The History of the Voice of Women." PhD dissertation, Ontario Institute for Studies in Education, 1994.

${ }^{50}$ The transferability of 'radical liberalism' among movements can only apply to equalityseeking groups.

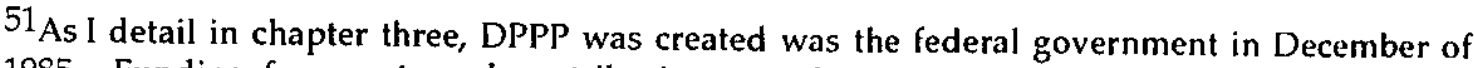
1985. Funding for grants and contributions to advocacy and consumer-controlled service provision disability organizations was set at $\$ 3.2$ million annually. The programs mandate was to "provide technical and financial assistance to disabled persons voluntary organizations for activities designed to encourage the full participation of disabled persons in Canada." See, Canada, Secretary of State, Annual Report 1985-1986, (Ottawa: Supply and Services Canada, 1986). 


\section{CHAPTER THREE}

\section{INITIATIVES AND RESPONSES: \\ The Federal State and Disability Movements Since 1970}

\section{Introduction}

There is a growing literature which examines federal state support to Canadian voluntary groups. The tactics, goals, impacts and outcomes of federal funding of women's, visible minority, second official language, and First Nations organizations have all been scrutinized (Burt, 1986; Findlay, 1987; Ng, 1988; Phillips, 1991, 1992, 1994; Pal, 1993). The extension of federal support to Canadian disability movements, however, has attracted little attention to date. In this chapter, I explore a question identified by Susan Phillips, but with reference to the movement of PWDs: "How does the political opportunity structure affect the mobilization, development, impact, and demise of movements?" (1994: 196). My central goal is to explore the character of the relationship between the Canadian federal state and disability movements through a case study of the Canadian Independent Living.

I begin by providing a brief overview of Canadian movement literature focusing on how this literature assists in explaining the activism of PWDs in Canada. There is little literature accounting for movement activity which is grounded in 'Canadian experiences' mainly because Canadian scholars have chosen theoretical 'products' from the U.S. or European traditions. The importance of place/territory, climate, sparse population and federalism largely have been overlooked. This has resulted in, at best, a partial understanding of movement activity in Canada, and in particular, of the activism of PWDs and their movements. Next, my analysis shifts to consider 
why the federal government responded positively to movements of persons with disabilities in the late-1970s and 1980s. ${ }^{1}$ My aim here is to provide an overview of the political environment in which disability movements found themselves placed.

In the third section, I examine federal initiatives relating to disability and federal responses to disability movements beginning in the 1980s. My analysis focuses on three key areas-policy, programs and funding. Finally, in the last section, I examine the interaction between the federal government and the Independent Living movement. Focusing on the extension of federal support for the Independent Living wing of the movement, I show that Independent Living as it has developed in Canada is quite different from its service-delivery origins in the United States. The federal government viewed IL as an attractive alternative to more traditional, state-supported, service-delivery model. Members of the Canadian Independent Living movement, however, embraced the citizenship model, fostered through the SOS, and defined their goals within the parameters of self-advocacy and selfdetermination.

\section{I}

Grounding Disability Movements in "Canadian Realities:"

Canadian Treatments of Movement Theory

A central theme of this study is that movement activity in Canada is somewhat different from that of other western democracies. But there is little literature detailing movements from within a 'grounded' Canadian framework. William Carroll suggests that there is "a dearth of available texts that probe the meaning of movements in a distinctively Canadian context" (1992: 1). Indeed, there is little Canadian literature accounting for movement 
activity which is grounded in "Canadian realities" (Vickers, 1995) largely because Canadians have chosen theoretical 'products' produced out of European or U.S. experiences. Recently, some literature has emerged examining the Canadian women's movement from a 'grounded' Canadian perspective (Vickers et. al., 1993), but most of the work examining movement activism in Canada continues to adopt the imported European or U.S. theories.

This imported literature falls largely into two distinct schools of thought. The New Social Movement (NSM) approach developed out of the European tradition and was championed by scholars such as Alain Touraine (1981, 1988), Alberto Melucci (1988, 1989) and Carl Boggs (1986). As a theoretical framework, the NSM approach challenged the reductionist structuralism in Marxism and is concerned primarily with uncovering the nature of movement actors. It asserts that only post-materialist or counterhegemonic movements are 'really new'. Not surprisingly, NSM approaches ignore disability movements totally because these movements, although arguably the only truly 'new' movements in the post-WW2 period, simply cannot be post-material. People with physical disabilities, for instance, have concrete material needs (i.e., a wheelchair) which cannot be overlooked during a discussion of their movements. Nor, as I will demonstrate, can they be counter-hegemonic vis-à-vis the state, although they are 'radical' in challenging medicalization and the normative identity assigned to PWDs.

The second framework, known as Resource Mobilization Theory (RMT) was developed primarily by U.S. social scientists Charles Tilly (1978, 1985), Mayer Zald and John McCarthy (1979, 1987), William Gramson (1968, 1975), J. Craig Jenkins (1983) and Anthony Oberschall (1973). This approach has been used effectively by feminist scholars as Joyce Gelb (1989) and Sylvia 
Bashevkin (1994). RMT emerged as a reaction against traditional U.S. social science theories about collective action developed by Mancur Olsen in his now famous 1965 book The Logic of Collective Action which embraced rational choice and cost-benefit analyses of political actors. Despite the marked differences between these schools of thought, Eduardo Canel has observed that at the most basic level both the NSM and RMT approaches "seek to explain the emergence and significance of contemporary social movements in (post)industrial societies" (1992: 22). Similarly, "both approaches" Canel continues, "have reformulated traditional theories of collective action on each side of the Atlantic" (1992: 22).

Canadian feminist sociologist Lorna Weir, after reviewing the major contributors to social movement literature, concluded that three identifiable themes emerge to explain movement activity. They are:

(1) [the] material and status frustration generated by expectations which the welfare state has been incapable of fulfilling; (2) the politicization of everyday life through interventions of welfare state/capitalist modernization; [and] (3) the generation of new values resisting the institutional forces of instrumental reason (1993: 78).

While Weir successfully summarizes the central tenets of existing movement literature, her three themes do not capture the unique features of movements in Canada. Susan Phillips suggests, for example, that Canadian movements, like their counterparts in the United States and Europe, "have a profound impact on the conduct and consequences of politics" (1994: 188), but this activity, she continues, is "distinctive from that of other western democracies" (1994: 199).

Beginning to uncover these differences has become a central focus for a growing cadre of social scientists and movement activists. As I suggest below, there is an emerging scholarship probing these important differences, 
particularly around the importance of space and place in Canadian intellectual discourse (Cavell, 1994; Rankin and Vickers, forthcoming). Along with a number of groundbreaking feminist studies (Adamson et. al., 1988; Vickers, 1988; Vickers et. al., 1993), the Canadian centerpieces of movement theorizing include Social Movement/Social Change (1988), Organizing Dissent (1992), and a special issue of the Canadian Review of Sociology and Anthropology (1993). In brief, like the Europeans, most Canadian theorists have tended to focus on the ideological, rather than more structuralist orientation, of contemporary movement activity towards the political terrain (Galipeau, 1989; Kellough, 1992). Nevertheless, these studies do not help us fully understand Canadian disability movements because they do not address the important elements of geography and climate. There is an emerging literature, however, examining the importance of place, region and climate.

Richard Cavell argues that, in Canada, "space is inarguably the central category of intellectual discourse" (1994: 75). He shows that space/territory directly contribute to the construction of Canadian identities, as well as to the material experiences of Canadians. Pauline Rankin and Jill Vickers, in an article examining the "location of women's politics in Canada," accept Cavell's argument, but highlight that "especially [in] Canadian political science, space has been used as a totalizing concept which has lacked context and denied [the] political significance of sex/gender" (forthcoming). They conclude that "place matters" because "where women engage in politics" directly impacts the success of their activism both inside and outside state apparatuses and structures (Rankin and Vickers, forthcoming). For PWDs and their movements, the importance of place and climate is clear. Canada is a vast federal state which is geographically northern and sparsely populated. These elements are particular to the Canadian experience and directly impact 
the type, level, organizational structure and orientation of disability movements. In fact, the umbrella structure of most pan-Canadian, federal movement organizations including $\mathrm{CCD}$ and NAC is a consequence of Canada's vast size and sparse population. As I suggest later in this chapter, Canada's geography, climate and low population density have meant that Canadian disability movements required the support of the federal state for things such as transportation, sign language/bilingual interpretation and translation, and disability-related supports.

Many Canadian movement observers have also been active in discussion the role of the state in movement development (Magnusson, 1990; Mooers and Sears, 1992; Ratner, 1992). Barry Adam, for example, using a political economy approach, critiques the dominant theoretical trends within movement literature because it "jettison[s] history and political economy" when it concludes there is a "global shift towards postmaterialist values" (1993: 320). I contend, with Adam, that "[t]heorizing about...movements...needs to recognize that the differentiation and formation of subordinated categories of people are both a part of and apart from the political economy of advanced capitalism" (my emphasis, 1993: 325). Adam also maintains that movement literature fails "to take into account [the] ongoing struggles [movements have] with the state and capital" (1993: 317).

Susan Phillips mirrors Adam's in her work on Canadian movement organizations and networks by suggesting that "most Canadian NSMs have developed a closer relationship to the state than have their counterparts in many other countries" (1994: 199). Similarly, Lorna Weir points out that, while it is valid to argue that movements "are not purely statist", it is also the case in Canada that some strands of some movements (feminist, gay and ecological) have "made significant oppositional demands on the state" (1993: 
86). As this study shows, however, disability movements are not primarily counter-hegemonic in nature, but instead want to be included in the arena of the federal state and require state support. Nevertheless, after citing numerous examples of claims made on all levels of the state by women's, gay/lesbian and ecological movement groups, Weir concludes that:

Anyone with the barest acquaintance with Canadian social movements would find the claim that these are in the main characterized by a culturalist, lifestyle politics centred on civil society in abstraction from engagement with the state and economic demands true only of a small section of these movements (1993: 87).

My analysis has been influenced by the work of these Canadian scholars. It is clear that the Canadian disability movement, like most strains of women's movements in Canada, do not represent political activity which is solely or even mainly post-modern or post-materialist in orientation. In fact, rather than being suspicious of the institutions of the state, disability movements have, beginning in the 1970s, developed very close ties to federal, provincial and local levels of government. Nor is the movement's orientation uniformly left or anti-capital. There is little conflict over federal support to groups within the disability movement although this has been an important issue in other movements in Canada. As I detailed in chapter two, the Canadian disability movement is state-focused in two important ways: it relies heavily on the state for funding and views government as the best recourse for people with disabilities seeking to achieve change. The statefocused nature of the disability movement is neither simply a choice nor an opportunistic position; it is difficult to imagine how a pan-Canadian movement of PWDs could operate in Canada's vast space, except with some government support. It is equally difficult to identify any recourse for 
disability movements other than the state (at whatever level) given the regulatory and support needs of PWDs. ${ }^{2}$

As $I$ argued in chapter two, Canadian political opportunity structures involved an activist federal state in the 1970s and 1980s which supported "radical liberalism" (Vickers, 1992) and led disadvantaged groups to advance the right to self-advocacy as a citizenship right. It is my contention that for people with disabilities, the emergence of full citizenship rights required federal state support of their organizations through both the Departments of the then-Secretary of State and National Health and Welfare. In the 1990s, however, the activist tendency of the federal state which encouraged a radicalliberal political culture is being muted by a neo-liberal agenda committed to fiscal restraint, deficit reduction and citizens 'self-sufficiency'. As Janine Brodie notes, in her analysis of the changing Canadian state forms and public policy, the "new...citizen is one who recognizes the limits and liabilities of state provision and embraces the obligation to become...more self-reliant" (1996: 19). This has resulted in partial withdrawal from the federal state's commitment to support citizen activism by supporting organizations.

\section{II}

Setting the Context:

The Canadian Federal State and Movements of Persons with Disabilities

Why did the federal government responded positively to Canadian disability movements in the late-1970s and 1980s? In this discussion I use the analytic concept of political opportunity structure (POS) which theorizes how movements behave by considering the structural variables of the state which provide both opportunities and barriers to their activism in relation to state action (Gelb, 1989; Tarrow, 1989; Bashevkin, 1994). Susan Phillips maintains 
the "action choices" of movements "are never unrestrained, but are made in the context and within the limits imposed by the political opportunity structure" (1992: 263). Vickers, Rankin and Appelle (1993), in their political investigation of the National Action Committee on the Status of Women (NAC), (the English-Canadian women's movement largest organization), however, conclude that movements can also create their own opportunities and can also get state structures changed. For this analysis of the context in which the Canadian disability movement emerged, I focus on three elements which help shape the opportunities and barriers the disability movement faced vis-à-vis the federal state: (1) the general thrust of movement activism in the 1970s; (2) the international context; (3) Canadian federal government programs; and the Canadian Charter of Rights and Freedoms.

\section{The General Thrust of Movement Activism in the 1970s}

Beginning in the 1960s and 1970s, critical movements for change (re)emerged to extend civil, political, social and legal rights to disadvantaged individuals and groups throughout North America. Hasson and Ley suggest we can best understand this period as irtvolving a widespread "struggle to secure citizenship rights" (1994: 323). They maintain that "[t]he civil right of equal legal status...and the political right of participation in urban life...were extended-albeit haltingly and incompletely-over the 1960s and 1970s to lower class and minority groups" (1994: 324). In North America, the 1960s

and 1970s were decades of tremendous upheaval, change, and resistance to authority by many. The civil rights movements, the anti-war/peace movements, the student movements, and the women's movements, all indicate the increase in movement activity. 
In Canada, there is evidence of movement activity throughout the 1960 s, but it is in the 1970s that these movements become institutionalized in Canadian political discourse. Vickers, et. al., (1993) distinguish among three distinct movement types evident in Canadian politics: equality-seeking movements, such as women's, gay/lesbian, racial minority and disability movements; quality of life movements, which include peace and environment; and finally, reactive movements, which are mainly in opposition to the first two categories and seek to maintain or restore the status quo, including the 'pro-life' and 'pro-family' movements. Although different in orientation, all of these movements exist, the authors argue, because "people shared a vision of change (or restoration) and because existing political parties could not accommodate their ideas, personnel, and energy involved" (1993: 17).

Canadian women's movements are perhaps the most striking example movement activity which actually re-shaped federal state machinery; through the creation of the Canadian Advisory Council on the Status of Women (CACSW), the Women's Program within the Secretary of State, and a Minister Responsible for the Status of Women, for example. The demands made by women's movements on the federal state and its responses created an environment and infrastructure on which other movements could draw-including Canadian disability movements. Diane Driedger points to the early influence of the English-Canadian women's movement on disability organizing (1989: 11-12). The establishment of the Royal Commission on the Status of Women in 1967, and its Report released in 1970 shifted political discourse in Canada. Adamson et. al., argue it was at the end of 1971 that "the women's movement was [re]established as a force in Canadian society" (1988: 53). By 1972, the organizational infrastructure of the English-Canadian 
women's movement was established with the formation of NAC out by some 30 pre-existing groups. By 1982, NAC had some 320 groups and by 1988 there were 575 organizations affiliated with the organization (Vickers, et. al., 1993: $20,77)$. NAC and other women's organizations made many policy demands on government during this period. The federal government responded with: a developing commitment to role equality (as opposed to fundamental transformation of roles); incremental policy making; the segregation and dispersion of women's issues; and continued support for voluntary groups (Burt, 1986: 153).

For people with disabilities and their organizations, these developments created an environment which 'softened up' the federal government to demands for role equality and to a lesser extent role change. ${ }^{3}$ The tremendous social and political upheaval movements caused during this period led some PWDs to re-assess the passive, 'sick' role which institutions and the medical community had assigned to them. In the wake of the women's movement, First Nations movements, ethnic/racial minority movements and francophone movements, the Canadian disability consumer movement emerged at the federal level in the mid-1970s to assert that Canadians with disabilities were entitled to the same citizenship rights as all other individuals and groups in society. As Diane Driedger notes "in North America, the 1960s [and 1970s] and its political climate of social change spurred disabled persons to organize in the same way blacks, poor people and women were doing" (1989: 11-12).

\section{The Influence of the International Disability Context}

A second important factor in creating a positive environment for the development of Canadian disability movements was international, especially 
United Nations, activities. Michael Prince (1992) argues that, while Canada has always played a prominent role on disability issues at the international level, the international policy and organizational context also influenced domestic Canadian policy-making and political discourse concerning disability issues significantly since 1980 (1992: 197). I have divided the impact of these international influences on the Canadian federal state into two categories: first, UN policies and programs concerning disablement, and second, the influence of international non-governmental organizations (NGOs).

The United Nations first concerned itself concretely with disablement in 1971 when it affirmed the Declaration on the Rights of Mentally Retarded Persons and in 1975 with the Declaration on the Rights of Disabled Persons. These international declarations were to give concrete expression to the principles set out in the 1948 Universal Declaration of Human Rights (See Table 10). The rights contained within these early declarations are simply the right to respect for the human dignity of persons with disabilities; the right to civil and political rights; economic and social security; the right to live with family and the right to access pubic education. ${ }^{4}$ While Michael Prince points out that these UN declarations have served to provide "philosophical inspiration and pragmatic direction" (1992: 198) for federal and provincial governments to protect persons with disabilities in human rights laws and other forms of legislation, Evelyn Kallen asserts that human rights principles only set global standards to which all members states should conform (1989: 12). Kallen observes that "fundamental human rights...are prior to law" which means that "[1]aws themselves may violate human rights" (1989: 12). Nevertheless, there is agreement that the pronouncements, declarations and conventions of the UN expanded notions of individual and collective 
citizens' rights and contributed to the pace and direction of domestic public policy in many countries, including Canada (Cairns and Williams, 1985; Williams, 1985).

\section{TABLE 10}

Initiatives Undertaken by the United Nations concerning Persons with Disabilities

\begin{tabular}{ll}
\hline Date & Initiative \\
1948 & - Universal Declaration of Human Rights \\
1971 & - Declaration of the Rights of Mentally Retarded Persons \\
1975 & - Declaration on the Rights of Disabled Persons \\
1981 & - International Year of Disabled Persons (IYDP) \\
1982 & - Adoption of the World Program of Action on disabled persons \\
$1983-92$ & - Declaration of the 'Decade of Disabled Persons'
\end{tabular}

In the 1980s, the UN began to play a more active role in promoting the citizenship rights of persons with disabilities. Perhaps, most important was the United Nations International Year of Disabled Persons (IYDP) ${ }^{5}$ in 1981 and the World Program of Action (WPA) concerning Disabled Persons which was associated with the United Nations Decade of Disabled Persons (UNDDP), 1983-1992. The IYDP defined its goal as no less than "full participation and equality" of persons with disabilities and the elimination of the barriers they face. The UN established a trust fund with $\$ 1$ million to pay for projects concerning disability issues in various member countries representing the first time the international community took concrete action on disability issues. Governments of some countries responded with domestic initiatives. The purpose of the WPA was to "promote measures for prevention of disability, rehabilitation, and the realization of the goals of full participation and equality of opportunity of disabled persons in economic and social life" (Prince, 1992: 197).

While the IYDP, the WPA and the UNDDP are all important international influences on Canadian disability policy and programs many of 
the projects undertaken by member countries were severely curtailed because of lack of funds from the United Nations. Cherie Lewis argues that the "low level funding [from the UN] reflects a basic conflict within the United Nations...about the status of the disabled" (1994: 191). Nevertheless, the UN declarations also "put disability into a global context and posed the question of how [disablement] may be understood in a multicultural world" (Whyte and Ingstad, 1995: 3). Disablement discourse was widened to include discussions on disability from a cross-cultural perspective, in particular, the difference of meanings and experiences of disability affluent countries and poor countries. ${ }^{6}$

The actions of international organizations was one more reason why the federal government responded positively to the Canadian disability movement. Disabled Persons International (DPI) was founded in 1980 in Winnipeg by 250 PWDs from around the world who attended and lobbied for participation in the 1980 World Congress of Rehabilitation international (RI). Partially sponsored by the Canadian government, RI is an organization of and controlled by disability professionals, not by PWDs. DPI emerged out of the Congress as persons with disabilities tried to establish a united international voice of their own (Driedger, 1989; Lewis, 1994: 192-95). The organization is the only cross-disability organization in the world with member groups in more than 110 countries world-wide, mostly located in poorer countries. It remains the sole international, cross-disability voice of persons with physical, mental and sensory disabilities. ${ }^{7}$ Much of DPI's work is conducted in close collaboration with the UN, the World Health Organization (WHO) and the International Labour Organization (ILO).

Canada's role in DPI has been significant and ongoing. The Canadian International Development Agency (CIDA) provided funds for the DPI Secretariat to be located in Canada (Winnipeg), it contributed $\$ 100,000$ for 
DPI's first World Congress in Singapore in December of 1981, and subsequently provided DPI with $\$ 500,000$ in matching funds for the development of an international leadership training program (Prince, 1992: 194). To date DPI continues to receive sustaining, although reduced, funding from CIDA. Henry Enns, the chair of DPI, argues that the formation of DPI brought international disability issues into the policy arena in Canada. Indeed Enns notes "the Canadian government included a representative of DPI in the Canadian delegation to the UN Advisory Committee for the International Year of Disabled Persons in 1981" (in Prince, 1992: 194).

People First International and its national affiliates around the world is another important international non-governmental organization. People First is an organization of mentally disabled individuals who speak on their own behalf for social and political rights, including the right to live outside of institutions. The organization was formed in Portland, Oregon in 1974 as a response to a convention sponsored by the British Columbia Association for Retarded Citizens in Vancouver. By the late 1970s, People First chapters were being formed in Canada, Sweden and the United States, which led to the formation of People First International.

\section{Federal Programs Directed Towards Voluntary Organizations}

The Canadian disability movement has received ongoing funding from the federal government since its emergence in the mid-1970s resulting in a close relationship with the federal state. Much of the initial funding for the disability groups was secured through the Citizenship and Social Action Branches of the Secretary of State. Leslie Pal (1993) has undertaken a comprehensive analysis of the Citizenship and Social Action Branches of the SOS from its beginnings in the 1950s. His analysis locates federal state 
funding of NGO's and movement organizations in a broader conceptual framework.

$\mathrm{Pal}$ points out that the SOS had a history which dates back to Confederation, and, not surprisingly, its functions have varied over time (See Table 11). Since the late-1960s, however, the department had "primary responsibility for citizenship development and providing assistance for advocacy and service organizations" (Pal, 1993: 4). Pal's analysis centres on funding programs in three areas of the Citizenship Branch-the Official Language Minority Groups Program (established in 1969), the Multiculturalism Program (established in 1971), and the Women's Program (established in 1974). He maintains that although each program developed separately and had its "own characteristics," it nonetheless had some elements in common with the others.

Each funding program within the SOS was under the "rubric of citizenship development" (Pal, 1993: 148) and collectively they were part of the federal state's strategy. Pal argues the strategy was not co-optation or patronage, but rather each operated within a "macro-political framework" (1993: 122). Pal argues against assumptions that the federal state extended funding to the voluntary sector because it wanted to 'buy votes'. Instead, he concludes the government was operating out of a political framework which stemmed from three sources:

Threat to National Unity: The FLQ crisis in Québec in October of 1970 left the federal government greatly concerned witi national unity, so the extension of federal funding to voluntary organizations was to foster the development of a "citizenry attached to a single identity [being Canadian] through their differences" (1993: 122). 
New Liberal Agenda: These programs reflected the Liberal government's agenda once it came into power in 1968-it was one defined by ideas of the 'just society', participatory democracy and citizenship participation.

Rise of Movements: These programs reflected the federal state's growing concern with the increase level of unrest in North America. Pal argues that the level of unrest in Canada never matched that association with movements in the U.S. because Canadian policy-makers had time to assess movement demands and react within a Canadian context (1993: 121-2). The extension of funding to these sectors formed a central component of the government's response. Vickers et. al. (1993) show, however, that the government's response was possible because some movements were already state-focused dating back to the 1890s, in the case of women's movements.

\section{TABLE 11}

Central Focuses of the Citizenship Branch in the Secretary of State (1945-1989)

1945-59 Promotion of national unity and the integration of immigrants

Community development and community action-focus on the poor, urban renewal, students, First Nations peoples

1969-71 Citizenship participation (OLMG program, Multicultural Program)

1972-89 Broader citizenship participation-citizenship rights (Women's, Youth, First Nations peoples, Disabled Persons Program)

Source: Compiled by author from Pal, (1993).

The Citizenship and Social Action branch of the SOS provided a stimulus for the development and expansion of movement activity in Canada. In 1989, the Citizenship Development Branch of the SOS was responsible for the following programs: women, Native citizens, youth participation, disabled persons, community development, national literacy secretariat and management planning and research (SOS, Annual Report, 1988-89). In the third section of this chapter, I focus on the development of the disabled persons sector within the Citizenship Development program of the SOS. 


\section{The Canadian Charter of Rights and Freedoms}

The Canadian constitution has also served to create an environment in which social, political and legal claims from 'citizen groups' can be made against the state. Alan Cairns and Cynthia Williams predicted in 1985 the Canadian Charter of Rights and Freedoms (known hereafter as the Charter) "would have a transforming effect on the general conduct of politics and indeed on the very nature of consensus and understanding that underpin constitutional government in Canada" (1985: 34). Indeed, the intent of the Trudeau government concerning the Charter was to provide an instrument for nation-building, nation-preservation and rights-protection (individual and collective) (Cairns, 1995).

The inclusion of 'disabled persons' in Sections 15 (1) and (2) of the Charter was an achievement of Canadian governments (both federal and provincial) and the Canadian disability movement (Kallen, 1989: 16; Gadacz, 1994: 216). Canada remains the only nation in the world to include in the Constitution a clause according "equal protection and equal benefit of the law...without discrimination based on...mental or physical disability" (Constitution Act, 1982)

Although the Constitution Act became law in April of 1982, the equality rights provision of the Charter did not come into legal effect until April of 1985. As Michael Prince observes, however, "[t]he Charter provision...created the necessary belief for many individuals and groups that they really are full citizens and can demand a place in the mainstream" (1992: 212). Achieving protection for persons with disabilities in the Charter was a struggle. The initial hearings of the Special Joint Committee of the Senate and the House of Commons on the Constitution of Canada (the Hays-Joyal Committee) brought little support for the inclusion of disabled persons in 
Section 15. It was assumed that existing human rights legislation would adequately protect the needs of PWDs. The Hays-Joyal Committee became convinced that additional protection was necessary under the equality provisions in the Charter only when members of the disability movement made comprehensive presentations and submitted formal briefs to the Special Joint Committee (Driedger, 1984, Gadacz, 1994: 215). ${ }^{8}$ Disability movements could not have engaged in such self-advocacy, however, without the financial support of the federal state. The government provided funding for transportation and other related costs.

The constitutional guarantee of equality found in Section 15 of the Charter, unlike the U.S. anti-discrimination provisions found in the Americans with Disabilities Act of 1990 , is largely a conciliatory mechanism. The ADA is a broad piece of federal legislation which makes it illegal to deny, among other things, accessibility to PWDs at the federal, state, and local level of government, as well as in private industry. The Charter sets equality guidelines which the courts must interpret on a case-by-case basis through the legal system. In fact, the jurisdictional complexity of the Canadian federation probably precludes the possibility of passing federal legislation such as the ADA in Canada. Cairns and Williams conclude, nonetheless, that the Charter has successfully introduced the discourse of equality rights into the social policy mainstream:

The constitutional recognition of citizen rights in the 1982 Charter demonstrated the interplay and convergence of government efforts to shape conceptions of political community in Canada, and the demands and pressures exerted by mobilized, organized citizens able to adapt notions of fundamental citizen rights to the particular interests they represented (1985: 37).

It is clear that a number of elements created a POS at the federal level open to activism from the disability movement. The general thrust of 
movement activism, international influences, the existence within the SOS of programs to support national voluntary organizations and the impact of the Charter all provided the context for the disability movement to progress. In the next section, I examine the federal government's response to the goals of disability movement beginning in 1980 .

\section{III}

Contradictory Actions:

The Federal Government's Response to the Disability Movement Since 1980

Like the women's movement (Burt, 1986: 149), disability movements in Canada have been influenced by federal government initiatives. Indeed, it is my contention that the Canadian disability movement could not have developed as a movement to secure citizenship rights for PWDs without federal support during the 1980s. While the government significantly advanced the goals of the disability movement, initiatives undertaken in the mid-1990s such as program cutbacks to CAP and its proposed elimination and replacement with the Canada Health and Social Transfer (CHST) in 1996, cutbacks to federal social programs and the curtailing of federal funding to national voluntary organizations, work against many of the government's initiatives which advanced the social, political and economic rights of PWDs.

The federal government's responses to initiatives of the disability movement have always been fragmented because of the jurisdictional complexity of the Canadian welfare state. Although in 1995 the Liberals announced that much of the federal government's responsibility for social services will be transferred to the provinces with the implementation of the CHST (a block transfer for health care, post-secondary education and social assistance), responsibility for disability-related supports and services 
historically has been split among the federal, provincial and municipal governments. That said, I focus here exclusively on federal initiatives. Most initiatives were undertaken by the federal government because of the pressure the Canadian disability movement exerted on the federal state through the Standing Committee of Human Rights and the Status of Disabled Persons and its predecessors. Before examining the federal government's response to the disability movement in a more detailed way, however, I want to discuss the evolution of the Standing Committee, using its reports as a springboard for my analysis.

\section{Setting the Agenda: The Standing Committee on Human Rights and the Status of Disabled Persons}

Most disability initiatives at the federal level began in 1981 with the UN's declaration of the IYDP, with the theme "full participation and equality." Even before the IYDP was declared by the UN, however, Canada played an active role internationally on disability issues. Canada was active participant at the UN for the establishment of the IYDP and seconded the UN General Assembly resolution for the establishment of the IYDP in 1977. In anticipation of the IYDP and to commemorate its proclamation, the Canadian government undertook several initiatives domestically, among them the creation, in May of 1980, of the Special Parliamentary Committee on the Disabled and the Handicapped. In 1985, the Special Committee became the Sub-Committee on the Disabled and the Handicapped and in 1987, the Standing Committee on Human Rights and the Status of Disabled Persons was established. Like its predecessors, the Standing Committee acts as a 'think-tank' on disability policy and programs at the federal level. To date, the Special Committee, the Sub-Committee and the Standing Committee 
have tabled a total of eight reports concerning Canadians with disabilities (See Table 12).

The Committee structure implemented in 1980 has served as an important cornerstone for the advancement of disability initiatives within the federal government. A comprehensive review of these reports is beyond the scope of this investigation, but I do want to pay particular attention to the establishment of the Special Committee and the release of its first report, Obstacles in 1981 because a major impetus for the establishment of the Canaaian Independent Living movement stemmed from recommendations contained in this report, as I show in detail in the final section.

The Special Committee's mandate was to evaluate the scope and effectiveness of existing federal government programs for persons with disabilities, identify barriers limiting the participation of Canadians with disabilities in society and to suggest practical measures to overcome these barriers. The Special Committee was unique among the existing Committee structure in Parliament ${ }^{9}$ at that time (Prince, 1992: 207) because it was small with only seven members of Parliament, 10 had the authority to hire and fire staff, travel and to hold hearings anywhere in Canada. Having heard from 600 witnesses and received over 700 written briefs, the Committee tabled its report, Obstacles, in Parliament in February of 1981. Using the principles of equal opportunity for full participation, social responsibility for change and self-help, the Obstacles report made 130 recommendations in 20 issues areas all of which stemmed from eight broad objectives for Canadians with disabilities:

- Achievement of adequate income;

- Support for the promotion of self-help ideas and activities;

- Provision of technical aids and community support services;

- Equal benefits and protection under the law; 
- Equal opportunity of access to public buildings, facilities, and programs;

- Equal access to a full range of opportunities in employment, housing, education, transportation, recreation, sports and leisure, and communication and information;

- Provision of community support services to reduce or eliminate the need for institutional care;

- Improved quality of life for disabled people who live in institutional care facilities (Obstacles, 1981a: ii)

The report's recommendations, although broad, emphasized primarily the social and economic aspects of citizenship for PWDs. They addressed the social rights, civil rights (i.e., equality before the law) and political rights (e.g., voting, rights to stand for political office) of Canadians with disabilities as a means to these ends (Prince, 1992: 208). The Special Committee paid insufficient attention to the situation faced by First Nations peoples with disabilities only making ten recommendations. As a result, its report was heavily criticized by some First Nations groups for not considering comprehensively enough the 'special needs' of Native Peoples with disabilities who face the double oppression of being both Native and disabled. In December of 1981 (ten months after the first report), the Special Committee issued a follow-up report to the Obstacles report in which it analyzed in depth the particular needs of Native Peoples with disabilities. ${ }^{11}$

Over the course of the 1980s and early 1990s, the Parliamentary Committee's responsibilities have evolved in three main areas: policy development; consideration of proposed legislation; and scrutiny of existing legislation and departmental administration. Each report tabled by the Committee had its own particular focus, but in general, they all stressed the social, economic and political rights of PWDs and the goal of their integration into Canadian society. The Committee structure and process has been significant for the advancement of citizenship principles for PWDs and their 
organizations. The Committee established a public record of the concerns of the disability movement, the responses of the various mandated authorities within government, and the viewpoints of various recognized 'experts' on disability-related issues (Prince, 1992: 210). In addition, the Committee's effectiveness grew because it has been viewed positively by members of the disability movement. In fact, the disability movement perceived the Committee as an advocate of the movement within Parliament and therefore fully supported and co-operated with it. Henry Enns, speaking on behalf of the Canadian Independent Living movement, concluded that:

From our perspective as an independent living movement, we want to encourage you, we want to work with you, and we hope that you will continue and not get too frustrated because we have been at this thing for a long time and though we are frustrated we are going to continue (Canada, Standing Committee on Human Rights and the Status of Disabled Persons, Minutes, September 28, 1990: 28).

Francine Arsenault, the current chair of the Council of Canadians with Disabilities (CCD), the consumer disability movement's national organization, told the Standing Committee in 1993 that

[its work] represents a significant departure from the way in which government bodies in the past approached issues that affect people who have a disability. The leadership the committee has demonstrated has had both a direct and indirect impact, domestically and on the international scene (Canada, Standing Committee on Human Rights and the Status of Disabled Persons, Minutes, June 8, 1993: 94).

The Standing Committee on Human Rights and the Status of Disabled Persons was established during a period in Canadian politics when the advancement of disadvantaged groups (i.e., PWDs, women, Natives) citizenship rights was an important component of federal political discourse. Indeed, during the early 1980s, the federal state had an activist orientation which encouraged the citizenship participation of Canadians with disabilities 
and their organizations. ${ }^{12}$ This orientation is reflected in the Committee's mandate from the House of Commons: "[To] propose, promote, monitor and assess initiatives aimed at the integration and equality of disabled persons in all sectors of Canadian society" (Canada, The Grand Design, 1995: 3).

\section{TABLE 12}

\section{Summary of Parliamentary Actions Concerning Persons with Disabilities}

\begin{tabular}{|c|c|c|}
\hline Date & Report Title & Key Recommendations \\
\hline 1981 & Obstacles & $\begin{array}{l}\text { - emphasized social, economic and political rights of PWDs } \\
\text { - recommended for deinstitutionalization and the adoption of } \\
\text { Independent Living principles } \\
\text { - replace VRDP } 13 \text { with new legislation that is more } \\
\text { responsive to employment needs of PWDs } \\
\text { - establish a new comprehensive disability insurance program } \\
\text { to be integrated with CPP and QPP }\end{array}$ \\
\hline 1981 & $\begin{array}{l}\text { Obstacles: Follow-Up } \\
\text { Report }\end{array}$ & $\begin{array}{l}\text { - dealt specifically with First Nations peoples with } \\
\text { disabilities }\end{array}$ \\
\hline 1982 & $\begin{array}{l}\text { Progress Report to } \\
\text { Obstacles }\end{array}$ & $\begin{array}{l}\text { - presented a 'status report' of the government's response to } \\
\text { Obstacles-106 of the } 142 \text { recommendations had been acted } \\
\text { upon, but concluded they were not being dealt with quickly } \\
\text { enough } \\
\text { - called for the designation of a Minister Responsible for the } \\
\text { Status of Disabled Persons }\end{array}$ \\
\hline 1987 & $\begin{array}{l}\text { Challenge: Putting } \\
\text { Our House in Order }\end{array}$ & $\begin{array}{l}\text { - recommended that the federal government's ratio of } \\
\text { disabled to non-disabled employees in the federal civil } \\
\text { service was drastically low } \\
\text { - recommended that the Committee become a Standing } \\
\text { Committee of Parliament }\end{array}$ \\
\hline 1988 & $\begin{array}{l}\text { No News is Good } \\
\text { News }\end{array}$ & $\begin{array}{l}\text { - study of the Canadian media's portrayal and coverage of } \\
\text { Canadians with disabilities }\end{array}$ \\
\hline 1990 & $\begin{array}{l}\text { A Consensus for } \\
\text { Action: The Economic } \\
\text { Integration of } \\
\text { Disabled Persons }\end{array}$ & $\begin{array}{l}\text { - critically analyzed the economic production and consumption } \\
\text { activities of persons with disabilities, as well as the public } \\
\text { and private programs in place to assist Canadians with } \\
\text { disabilities to integrate into the market-place } \\
\text { - recommended that the development of a national economic } \\
\text { integration strategy be a priority of the federal government }\end{array}$ \\
\hline 1990 & $\begin{array}{l}\text { Unanswered } \\
\text { Questions }\end{array}$ & $\begin{array}{l}\text { - sharply criticized the government for its vague promises and } \\
\text { inaction concerning disability issues }\end{array}$ \\
\hline 1995 & $\begin{array}{l}\text { The Grand Design: } \\
\text { Achieving an 'Open } \\
\text { House' Vision }\end{array}$ & $\begin{array}{l}\text { - expressed concern that every major federal program dealing } \\
\text { with disability is changing or being eliminated } \\
\text { - calls for a renewed federal strategy on disability to ensure } \\
\text { the protection of Canadians with disabilities during the } \\
\text { implementation of the CHST }\end{array}$ \\
\hline
\end{tabular}


Each of the Committee's reports since Obstacles has been unanimous and consistently pointed to ways in which the access, participation and integration of Canadians with disabilities and their organizations could be attained through public policy and program initiatives. ${ }^{14}$

Nonetheless, the Committee structure of Parliament has limitations. There are numerous recommendations the Committee has made to Parliament upon which no or limited action was taken. Parliamentary Committees have limited resources and very little power beyond releasing their reports and formally requesting a response from the government. Even this is not guaranteed. The dissolution of Parliament in 1993, for example, left four of the Committee's previous reports and recommendations in limbo (Canada, The Grand Design, 1995: 5).

Despite these limitations, the Standing Committee on Human Rights and the Status of Disabled Persons and its predecessors have been effective in two importanit ways: (1) they have served as an important vehicle for the advancement of the goals of the Canadian disability movement concerning federal disability policy, programs and funding allocation; and (2) the disability movement has consistently supported and participated in the Committee's work. I now want to turn to a more detailed analysis of the major initiatives undertaken by the federal government concerning PWDs and their organizations since the 1980s. Since it is not possible to discuss every aspect in detail, my goal is to highlight the central initiatives in three areas-major policy initiatives; key program developments; and overall funding allocation. 
TABLE 13

Highlights of Federal Government Initiatives Affecting Persons with Disabilities Since 1980

1980 - Special Parliamentary Committee on the Disabled and the Handicapped established

1981 - Obstacles report released

1982 - Canndian Charter of Rights and Freedoms proclaimed

1983 - Secretary of State is designated the ministry responsible for the status of disabled persons

- Canadian Human Rights Act amended to include persons with physical and mental disabilities

1985 - Equality provisions (s. 15 (1)) in the Charter come into effect-including persons with disabilities

- Prime Minister Brian Mulroney acknowledges the United Nations Decade for Disabled Persons (1983-1992) with a statement of 11 principles to guide the federal government vis-à-vis persons with disabilities

- Benoit Bouchard designated Minister Responsible for the Status of Disabled Persons

- Disabled Persons Participation Program (DPPP) established-funding was increased five fold to $\$ 3.2$ million/year from fiscal year 1986-87 through 1990-1991

- Special Committee on the Disabled and Handicapped became a Sub-Committee of Parliament

1986 - the Employment Equity Act is passed

- Statistics Canada undertakes the Health and Activity Limitations Survey (HALS) represents the first comprehensive statistical overview conducted on persons with disabilities

1987 - Sub-Committee on the Disabled and the Handicapped became the Standing Committee of the House of Commons on Human Rights and the Status of Disabled Persons and therefore a permanent fixture of Parliament

- National Access Awareness Week is established and funded through DPPP

1988 - "The Special Initiative" is announced to support the development of Independent Living in Canada-funding comes from NHW and SOS

1989 - DPPP provided funding for the first conference on women with disabilities

1990 - Commitment to proceed with a post-censal survey on disability to establish a national database on disability-related issues-estimated cost of $\$ 6.4$ million over three years

1991 - National Strategy for the Integration of Persons with Disabilities (NSIPD) is announced-commitment of $\$ 158$ million over five years in ten federal departments

1992 - Bill C-78 passed-Omnibus legislation which amended six separate statutes concerning accessibility issues relating to persons with disabilities

- DPPP funds the National Aboriginal Network on Disability (NAND)

1993 - Major government re-organizations occurs resulting in the dismantling of the SOS and the creation of Human Resources Development Canada (HRDC) - citizenship/social development focus is replaced with employment focus

- Minister Responsible for the Status of Disabled Persons is removed

1994 - Liberal government undertakes comprehensive review of social security arrangements in Canada-releases green paper entitled Improving Social Security in Canada: A Discussion Paper

1995 - announcement that the Disabled Persons Participation Program is being eliminated in April of 1996

- announcement of the elimination of CAP and its replacement with the single block transfer, the CHST 


\section{Key Federal Disability Policy Initiatives Since 1980}

Since 1980, there have been three different governments in power at the federal level. While this complicates discussions of federal initiatives, Michael Prince, in his review of federal disability policy from 1980 to 1991, suggests that federal disability initiatives are best summarized simply as "one step forward and two steps back" (1992: 233). Both the Trudeau and Mulroney government's implemented a number of strategic policy and program initiatives, but in the late 1980s many of these initiatives were thwarted by expenditure restraints and program cutbacks. With the election of the Liberals in 1993, this tendency has become more pronounced. As I discuss below, the current government has adopted a neo-liberal philosophy which is driven primarily by the goals of fiscal constraint and deficit reduction undermining past federal disability initiatives.

The federal government was slow to respond to the recommendations contained in the Obstacles report. In October of 1985, the Sub-Committee on Equality Rights ${ }^{15}$ noted in its report Equality for All that there were many bureaucratic delays and ineffective federal co-ordination in the implementation of the recommendation contained in Obstacles. Furthermore, it rejected the legitimacy of the government's argument that delays were because of the costs involved with the recommended changes (Canada, Equality for All, 1985: 75-93). Nevertheless, throughout the 1980s the federal government did take some action on disability initiatives. I have highlighted some of the most important in Table 13.

Federal Legislation: The named inclusion of 'disabled persons' in the Section 15 (1) and (2) of the Charter (1982) and the protection against discrimination 
because of physical and mental disability under the Canadian Human Rights Act (1983) are important advancements for Canadians with disabilities during this period. ${ }^{16}$ In 1985, the equality rights provisions of the Charter came into force under the Constitution. As well, the implementation of the Employment Equity Act (1986) required all federally-regulated employers, Crown corporations and grant recipients to report on efforts to hire and promote persons with various disabilities. ${ }^{17}$ In 1988, the National Transportation Act was amended to provide greater accessibility to the public transportation system for persons with disabilities. Finally, in 1992, Bill C-78, An Act to Amend Certain Acts with Respect to Persons with Disabilities, received Royal Assent. This Omnibus legislation amended six separate statutes concerning accessibility issues relating to persons with disabilities. The statutes affected were: thic Ariess to Information Act, the Citizenship Act, the Criminal Code, the Canada Elections Act, the National Transportation Act, and the Privacy Act.

Administrative Arrangements: In 1985, as a response to the UN's Decade of Disabled Persons, 1983-92, Prime Minister Brian Mulroney announced a set of eleven principles concerning PWDs which would direct and guide federal government actions. In the same year, the federal government designated a Minister Responsible for the Status of Disabled Persons (which was discontinued in 1993). ${ }^{18}$ This designation was based on the model of having a Minister Responsible for the Status of Women and represented the first time a member of cabinet was explicitly accountable for the federal government's initiatives concerning PWDs. Shortly after the new Minister assumed responsibilities in this position, the government announced the creation of the Status of Disabled Persons Secretariat (SDPS) within the SOS. Its mandate 
was to coordinate all federal actions concerning persons with disabilities and it marked the first permanent unit within the federal bureaucracy concerning policies and programs relating to disability (Prince, 1992: 216).

Income Provisions and Disability-Related Supports: While this investigation does not focus on the provision of programs and services for individual PWDs, it is important to note that for most individuals with disabilities, income provisions and disability-related supports are the most important element of the federal government expenditures. As a result, I briefly highlight them below.

The delivery of disability-related supports and services is a responsibility of the provinces and territories. Since the mid-1960s, however, federal taxes have paid for some of the cost for these programs through costshared programs such as Canada Assistance Plan (CAP) ${ }^{19}$, the Established Program Financing (EPF) and the Vocational Rehabilitation for Disabled Persons (VRDP) agreements. All of these cost-sharing agreements between the federal government and the provinces/territories serve as important tools financially to assist PWDs. These programs have been important because revenue sharing for program expenditures has addressed disparities among regions and provinces. It has enabled smaller, less prosperous provinces and territories, to enter into cost-sharing agreements with the federal government so that they can offer programs for PWDs which they otherwise would be unable to afford.

The disabled-related income system is an equally important component of the Canadian welfare state for PWDs. It is delivered by provincial, municipal and territorial governments, and like disability-related supports and programs, is funded through cost-shared agreements such as 
CAP. The system has been heavily criticized by the disability movement because of its fragmented nature across jurisdictions and between public and private systems. Individual benefits vary from province to province, territory to territory based on presumed differences in income requirements and needs-based testing within each province or territory. As I discuss below, however, all of these arrangements will change significantly with the elimination of CAP and its replacement, in April of 1996, by the Canada Health and Social Transfer (CHST).

Key Federal Program Developments and Funding Allocation Since 1980

The federal government's program development and its funding allocations to disability are inextricably linked so I deal with them together in this section. The program initiatives undertaken in the $1980 \mathrm{~s}$ advanced Canadian disability movements, and in particular, the Canadian Independent Living movement. The government's two key programming initiativesthe Disabled Persons Participation Program (DPPP) and the National Strategy for the Integration of Persons with Disabilities (NSIPD) - had monies directed to their establishment.

Disabled Persons Participation Program (DPPP): In December of 1985, the same year the SDPS was established, the federal cabinet made a program commitment to disability issues. Cabinet agreed to separate funding for consumer disability organizations from the existing Volunteer Action Program which had provided limited funding for disability initiatives. Instead, Treasury Board supported, and the Minister Responsible for the Status of Disabled Persons created, the Disabled Persons Participation Program within the SDPS. The programs objectives were grounded in the principles of 
citizenship participation and were consistent with the philosophy of the Obstacles report (Prince, 1992: 216). Nowhere is this more clear than in the program's three guiding principles:

- to enhance the capacity for disabled persons to represent effectively their rights and responsibilities as Canadian citizens;

- to support the development of community based mechanisms aimed at addressing attitudinal, institutional, and informational barriers that exclude disabled persons from integration into Canadian society; and

- to facilitate the development by disabled persons of innovative approaches to participating fully in the social and economic life of Canada (Price Waterhouse, 1991: 17).

The funding program was to support consumer-controlled, disability organizations addressing barriers of social, economic and political integration. The 1985-86 Annual Report from the SOS states that DPPP was to "provide technical and financial assistance to disabled persons' voluntary organizations for activities designed to encourage the full participation of disabled persons in Canada" (Canada, Secretary of State, Annual Report, 1985-86: 31)

With the creation of DPPP, Cabinet approved an increase in funding disability initiatives that amounted to $\$ 16$ million over five years (including fiscal year 1986-87 through 1990-91) in the form of grants to disability consumer organizations (See Table 14). ${ }^{20}$ In fiscal year 1986-87, contributions to disability organizations increased to $\$ 3.2$ million from the previous year's level of $\$ 837,000$. In addition, $\$ 1$ million was approved in $1986-87$ for the 'Rick Hansen Man in Motion Canadian Trust Fund'. As well, an additional $\$ 559,000$ was granted in $1986-87$ to support the development of the Walter Dinsdale Disability Information Resource Centre in Calgary and in 1989-90, funding amounting to $\$ 2$ million was given to the University of British Columbia for the establishment of the 'Rick Hansen Centre'. 
TABLE 14

Grants and Contributions by the Disabled Persons Participation Program (1981-1997)

\begin{tabular}{|c|c|c|c|}
\hline Year & $\begin{array}{c}\text { Funding Level } \\
\text { (in thousands of } \\
\text { dollars) }\end{array}$ & Number of Grants & $\begin{array}{c}\text { \% of Social } \\
\text { Development } \\
\text { Activity }\end{array}$ \\
\hline $1981-82$ & $\$ 478$ & n/a & 0.8 \\
\hline $1982-83$ & 876 & n/a & 0.9 \\
\hline $1983-84$ & 800 & $n / a$ & 0.9 \\
\hline $1984-85$ & 832 & n/a & 0.8 \\
\hline $1985-86$ & 837 & n/a & 1.0 \\
\hline $1986-87$ & 4,000 & n/a & 4.9 \\
\hline $1987-88$ & 3,500 & 239 & 4.3 \\
\hline $1988-89$ & 4,100 & 245 & 4.7 \\
\hline $1989-90$ & 3,500 & 266 & 4.4 \\
\hline $1990-91$ & 3,400 & 263 & 5.3 \\
\hline $1991-92$ & 7,300 & 300 & 9.0 \\
\hline $1992-93$ & 6,800 & 325 & 8.8 \\
\hline $1993-94$ & 7,000 & 375 & 8.9 \\
\hline $1994-95$ & 11,700 & 375 & n/a \\
\hline $1995-96$ & 11,900 & 400 & n/a \\
\hline $1996-97$ & DPPP is eliminated from the Status of Disabled Persons Secretariat \\
\hline
\end{tabular}

Source: Canada, Treasury Board, Part III Estimates.

Notes: a The Social Development activity (which had until 1992 been called Citizenship Development) includes the Women's Program, Native Friendship Centres, Aboriginal Language Representative Organizations, Youth Initiatives and Community Development programs.

b Prior to 1985, funding to disability organizations was disseminated under a DPPPlike model known as the Handicapped Participation and Voluntary Action programs. c Fiscal years 1981-82 through 1993-94 are actual expenditures, with fiscal year 199495 is a forecast and fiscal year $1995-96$ is an estimate.

National Strategy for the Integration of Persons with Disabilities: In 1991, the federal government launched the NSIPD for the Integration of Persons with Disabilities (NSIPD). Its establishment was largely a response by the government to the recommendations contained in the June 1990 report of the Standing Committee on Human Rights and the Status of Disabled Persons entitled $\underline{A}$ Consensus for Action: The Economic Integration of Disabled Persons. Their report detailed the major issues facing Canadians with 
disabilities in the 1990s and recommended, among other initiatives, that "the economic integration of persons with [become] a continuing national priority" (Canada, A Consensus for Action, 1990: 35). The NSIPD committed $\$ 159.35$ million over five years (fiscal 1991-92 through 1995-96) involving ten federal government departments and agencies (See Table 15a). As I discuss in greater detail below, while the overall budget remained unchanged, the 1993 federal government restructuring changed the federal departments involved in the NSIPD. This ultimately changed the initial of the National Strategy from citizenship initiatives to employment programs (See Table 15b). Through its original three goals-equal access, economic integration and effective participation-the activities by the federal departments and agencies were to fall into five areas: employment and training opportunities; community integration; partnership development; information exchange and coordination; and access to transportation, housing and communication.

The lead department in the coordination of the NSIPD was the SOS through the SDPS. Of the $\$ 38$ million allocated to the SOS, $\$ 14$ million was directed to DPPP to support consumer disability organizations. This new funding targeted, in particular, Aboriginal, women's, multicultural and rural disability organizations. As well, monies from the NSIPD ensured that existing national consumer disability organizations, including C.CD and CAILC, would continue to receive federal support. The NSIPD has been criticized, however, because the government lacked an overall coordinated approach to the implementation of the its goals (Canada, The Grand Design, 1995: 10-12). Nevertheless, it is clear that the monies made available through the NSIPD ensured federal support for disability consumer organizations. The NSIPD created a separate and secure pool of money for disability initiatives within the federal government. While many other programs were 
being cut, for instance, women's programs, disability initiatives remained intact.

\section{TABLE 15a}

\section{Funding Under the NSIPD by Federal Department and Agency} (at time of Treasury Board 1991 decisions)

\begin{tabular}{|l|c|c|}
\hline \multicolumn{1}{|c|}{ DEPARTMENT/AGENCY } & $\begin{array}{c}\text { TOTAL FUNDS } \\
\text { (in millions) }\end{array}$ & $\begin{array}{c}\% \\
\text { OF TOTAL }\end{array}$ \\
\hline Communications Canada & $\$ 5.7$ & 3.6 \\
\hline Canada Mortgage and Housing Corporation & $\$ 13.1$ & 8.2 \\
\hline Employment and Immigration Canada & $\$ 19.9$ & 12.5 \\
\hline Health and Welfare Canada & $\$ 46.0$ & 29 \\
\hline Indian and Northern Affairs Canada & $\$ 5.0$ & 3.1 \\
\hline Justice Canada & $\$ 1.2$ & 0.7 \\
\hline Labour Canada & $\$ 2.3$ & 1.4 \\
\hline National Library & $\$ 2.3$ & 1.4 \\
\hline National Transportation Agency & $\$ 0.9$ & 0.5 \\
\hline Secretary of State & $\$ 38.0$ & 23.9 \\
\hline Transport Canada & $\$ 24.6$ & 15.5 \\
\hline TOTAL & $\$ 159.3$ & 100 \\
\hline
\end{tabular}

Source: Standing Committee, The Grand Design (1995): 8.

TABLE 15b

Funding Under the NSIPD by Federal Department and Agency (after the 1993 restructuring of the federal bureaucracy)

\begin{tabular}{|l|c|c|}
\hline \multicolumn{1}{|c|}{ DEPARTMENT/AGENCY } & $\begin{array}{c}\text { TOTAL FUNDS } \\
\text { (in millions) }\end{array}$ & $\begin{array}{c}\% \\
\text { OFTOTAL }\end{array}$ \\
\hline Canadian Heritage & $\$ 0.58$ & 0.4 \\
\hline Canada Mortgage and Housing Corporation & $\$ 13.1$ & 8.2 \\
\hline Health and Welfare Canada & $\$ 6.7$ & 4.2 \\
\hline Human Resources Development Canada & $\$ 99.0$ & 62.2 \\
\hline Indian and Northern Affairs & $\$ 5.0$ & 3.1 \\
\hline Industry Canada & $\$ 5.8$ & 3.6 \\
\hline Justice Canada & $\$ 1.2$ & 0.8 \\
\hline National Library & $\$ 2.4$ & 1.5 \\
\hline National Transportation Agency & $\$ 0.9$ & 0.6 \\
\hline Transport Canada & $\$ 24.6$ & 15.5 \\
\hline TOTAL & $\$ \mathbf{1 5 9 . 3}$ & $\mathbf{1 0 0}$ \\
\hline
\end{tabular}

Source: Standing Committee, The Grand Design (1995): 9. 
It is important to highlight that while the DPPP and the NSIPD are important programs, disability movements and their organizations received federal funding through the SOS prior to their establishment. COPOH, for example, secured core funding through the SOS in the late-1970s. The extension of federal funding to disability organizations, therefore, has been ongoing since the late-1970s. Without the financial and technical support of the federal government it is unlikely disability movements would have been successful in achieving the development of a pan-Canadian network. As one government official told the Standing Committee on Human Rights and the Status of Disabled Persons,

[The] funding made available through the [Status of Disabled Persons] secretariat to organizations of persons with disabilities has been a major catalyst in the growth of the disabled persons' movement in Canada and has enabled persons with disabilities to more effectively participate in community life (Canada, Standing Committee on Human Rights and the Status of Disabled Persons, Minutes, April 26, 1994: 6)

The question that must be asked is: why has the federal government provided ongoing funding to disability organizations?

I maintain that the complexity of the Canadian polity and Canada's vast geography, northern climate and sparse population are all central considerations. Prior to the broadening of the welfare state to include the federal level beginning in the 1950s, disability issues were largely a provincial and/or local responsibility. The increased federal focus through the development of the contemporary welfare state, however, meant that disability organizations had to organize at the federal level. Without the support of the federal government, disability organizations could not have organized federally and developed pan-Canadian networks. Indeed, Canada's vast geography and more importantly, its sparse population mean that PWDs 
cannot achieve and maintain a 'critical mass' of individuals to mobilize effectively. Federal support provided subsidies for travel, accommodation and administrative costs related to the development of pan-Canadian disability networks and shared institutions such as CAILC and its affiliated ILRCs.

With the end of the NSIPD in April of 1996, however, the future of federal disability initiatives remains unclear. Despite continued support for employability initiatives, there is certainly evidence to suggest the federal government has abandoned its commitment to disability initiatives, and in particular, support for consumer disability organizations in the 1980s. My discussion now turns to examining this hypothesis in more detail.

\section{A Changing Environment: Federal Disability Initiatives in the Mid-1990s}

Beginning in 1993, we can identify a general shift in the area of federal disability initiatives away from the participatory citizenship principles of the 1970s and 1980s toward an approach focused on economic and employment concerns. This shift affected both disability consumer organizations which have developed largely as a result of the funding made available through the SOS and individuals with disabilities who depend on federally-regulated or cost-shared income support and disability-related support systems. For people with disabilities the federal withdrawal of support has been pronounced.

Consumer Disability Organizations: At the federal level, the withdrawal of sustaining support for movement groups began in the late 1980s under the Mulroney Conservatives and has become more pronounced under the Chrétien Liberals. ${ }^{21}$ Former Prime Minister Kim Campbell, in her short term in office, initiated a major structural reorganization of the federal state 
which the Liberal government continued to implement when elected in 1993. As a result of this reorganization, parts of the SOS were merged with other federal departments to form a new department called Human Resources Development Canada (HRDC). 22 The existing programs for disability groups were placed within this department as was the Women's Program of the SOS. Multicultural, official language minority and multicultural programs were placed within the newly created department called Heritage Canada. In the name of deficit reduction, the government disbanded the Canadian Advisory Council on the Status of Women (CACSW) in 1994 assigning most of its functions to Status of Women Canada. The future of the Council's research function is still undecided.

Throughout the 1980s, the federal government undertook initiatives which advanced the citizenship rights of Canadians with disabilities. The 1990s, however, have been marked with the reversal of a number of these accomplishments. The Minister Responsible for the Status of Disabled Persons position vanished entirely during Kim Campbell's short tenure as Prime Minister in the summer of 1993 in the restructuring of the Cabinet and the amalgamation and renaming of federal government departments. This has left Canadians with disabilities unrepresented by a designated Minister both in the Cabinet and in the House of Commons. The Standing Committee on Human Rights and the Status of Disabled Persons, however, remains intact.

In April, 1996, a number of government actions will effectively end federal support for disability movements (See Table 16). Two aspects deserve particular attention. First, the NSIPD is coming to an end and a new initiative is not expected. Second, in April of 1996, DPPP, the federal government's disability grants division will close and the money will be 
redirected into employment initiatives operating out of a new division known as 'Employability and Social Partnerships'.

\section{TABLE 16}

Federal Disability Initiatives which are Under Review or Slated for Elimination

- the federal/provincial Vocational Rehabilitation of Disabled Persons (VRDP) agreements expire in 1996 (and have been frozen at 1994-95 levels);

- the elimination of the Canada Assistance Plan (CAP) and its incorporation into the Canada Health and Social Transfer (CHST);

- the mandate of the National Strategy for the Integration of Persons with Disabilities (NSIPD) expires in March of 1996;

- the closure of the Disabled Persons Participation Program (DPPP) within HRDC-funding to community-based disability organizations is being eliminated

- the shift in focus within HRDC from social/citizenship issues toward economic and employment interests;

- the benefits and contribution of the Canada Pension Plan (CPP) are currently under review

Source: Standing Committee, The Grand Design (1995): 3-4

In their most recent report, The Grand Design: Achieving the 'Open House' Vision, the Standing Committee on Human Rights and the Status of Disabled Persons expressed concern that the federal government's disability policy and programs have lost their citizenship focus (1995: 9-10). Nowhere is this more clear than in the Department of Human Resources Development with its exclusively economic focus. The citizenship priorities of the SOS were lost once it was amalgamated with sections of four other federal departments. In 1991, for instance, the NSIPD was controlled by the SOS and its focus was on citizenship rights. By 1996, however, the program was being directed by HRDC and its citizenship focus has been replaced by economic issues and a focus on employability. In The Grand Design, the Standing Committee observes that "HRDC officials [have noticed] a departmental focus towards economic issues and away from social development" initiatives (1995: 14). In light of this, the Committee states: 
Employment may be the single most important issue in assuring integration. But it can serve neither as a panacea nor an excuse for failing to address issues related to income security and pensions, quality of life, physical accessibility, transportation, citizenship rights and responsibilities, communications, housing, de-institutionalization, the criminal justice system or education (1995: 10)

This shift in the department's focus is important particularly if we consider that as a result of the 1993 government restructuring process HRDC. was responsible for $\$ 100$ million (62\% of the funding allocation) of the NSIPD. Prior to the federal restructuring the SOS had been allocated $\$ 38$ million (24\% of the NSIPD) which was largely directed to citizenship initiatives. The SOS and its programs were amalgamated into HRDC, the socalled mega-department. Department officials and members of the Canadian disability movement expressed concern that in this new home "disability issues were receiving a low priority" (Canada, The Grand Design, 1995: 14). The government's direction is no longer defined by the goals of achieving self-advocacy and enjoying self-determination. Instead it is narrowly focused on economic and employmenc initiatives. This shift, Janine Brodie argues represents "a major transformation to make [the social safety net] fit with the market-based, self-reliant, and privatizing ideals" of neo-liberalism (1996: 19). Indeed, Brodie continues by pointing out in the federal government's Green Paper, Improving Social Security in Canada (1994), on redesigning social security arrangements, states that "[i]mproved government support must be directed to those [individuals and groups] who demonstrate a willingness and commitment to self-help" (in Brodie, 1996: 19). Additionally, government reforms are targeted to "help individuals achieve the satisfaction and dignity of work" (Brodie, 1996: 19). 
Individuals with Disabilities: Despite the commitments made by federal, provincial and territorial governments to coordinate income and disabilityrelated supports in the Mainstream 1992 report, in the mid-1990s the federal government is also beginning to abandon its responsibility for the cost-shared provisions directed towards income and disability-related supports and services. At this point it is still unclear what the impact of the current trend of federal decentralization to the provinces and territories of funding and policy control of social services (i.e., social assistance and health care) will be for PWDs and their organizations. In The Grand Design the Standing Committee reports that members of the disability community are concerned these changes will negatively impact PWDs in ways which will compromise "their ability to participate as citizens" (1995: 19).

Indeed, increased provincial autonomy over social services through the CHST to be in effect by April 1996 will certainly result in a loss of Canadawide standards in services and programs delivered by the Canadian welfare state which is a complex amalgam of programs at all levels. Briefly, the federal government will replace existing funding with the provinces for social welfare, education and health through CAP and EPF with a single block funding mechanism called the CHST. ${ }^{23}$ Each province will receive a fixed amount of financial support from the federal government through a combination of cash payments and tax points. James Rice (1995) rotes, however, that the size of "the super block" will be "totally independent" of provincial demand for these programs. (The allocation of the funds transferred to the provinces and territories will relate to the population size of the jurisdiction. This suggests, therefore, that size of the funding block is not "totally independent" of provincial or territorial demand). Rice argues 
further that "the federal government will be free to set its expenditure levels based on financial and deficit reduction considerations" (1995: 186).

Specifically, Rice concludes that the CHST will alter fundamentally social services in three ways: (1) there will be a loss of Canada-wide standards because the block funding arrangements offer no incentive for the provinces to provide a level of minimum services; (2) the federal commitment to the development of universal, substantive rights potentially has been abandoned; and (3) the provinces have been placed in a position which is vulnerable to fluctuations in the economy because they may not in a position to meet the demands for social assistance (1995: 205-6). It is still too early to detail the complete impact of the CHST on people with disabilities and their organizations, but Rice asserts that:

The greatest casualties of the [new spending arrangements] will be those people who are most in need of the benefits provided under the old CAP mechanism: single parents, disabled people, the unemployed employable and lower income families...The CHST makes no attempt to ameliorate the conditions faced by these individuals and families (my emphasis, 1995: 206).

Janine Brodie, with Rice, warns of federal government reforms premised on "the neoliberal consensus" (1996: 4). Indeed, one cannot deny that the impact of the changing nature of federalism for PWDs and their organizations will be pronounced. But, a distinction between the norms of neo-liberalism and the process of de-centralization must be made, especially as it relates to PWDs. I agree with Brodie that the neo-liberal consensus has shifted the federal state's priority of citizenship rights to fiscal constraint and employability, which I maintain will have a negative impact on PWDs and their organizations. But, the process of de-centralization, particularly as it relates to PWDs, may be a positive development for Canadian federalism.

Brodie places too much emphasis on the federal state when she 
advances her theory about the "hollowing out [of] the welfare state" (1996: 16). She assumes that if the federal state does not provide services and supports for its citizens, then no one will. As I detailed earlier, prior to the 1960s, responsibility for social services was located, not at the federal level, but at the provincial and local level of government. It may be that local levels of government are better suited to provide supports and services for individuals living in a particular geographic region, as opposed to a more general panCanadian response. That said, those regions which cannot provide the necessary supports and services for whatever reason, must be compensated by the federal state. De-centralization for PWDs is only viable if the federal state continues to play a role, albeit a smaller one. De-centralization should not mean, however, a re-casting of citizenship for those individuals who require state support; that is, the neo-liberal consensus.

In this section I have surveyed, generally, the federal government's initiatives as they affect PWDs and their organizations. Through an analysis of federal policy, programs and funding, I have argued that the disability movement has been created largely out of the support of the federal government. Beginning in the mid-1990s, however, federal support for disabilities initiatives, including disability organizations, has declined in favour of policies and programs with goals of economic integration and deficit reduction. While the federal government is axing funding to the main disability advocacy organizations, it has continued to provide core funding to the Independent Living movement. The extension of federal support to CAILC was set to expire in April, 1996, but in February the federal government announced it would provide core funds for fiscal year 1996-97. In the last section, I detail the evolution of state support for the Independent Living movement at the federal level and explore why the federal 
government continues to support this wing of the Canadian disability movement while withdrawing support from the movement's other organizations.

\section{IV}

\section{A Case Study: \\ Federal Support for Independent Living in Canada ${ }^{24}$}

In the 1980s, the federal government's response to the disability movement resulted in a significant, long-term investment in Independent Living. In this section, I focus on the federal government's support of this wing of the Canadian disability movement. It will become clear that the Canadian Independent Living movement, although 'invented' in the United States, is largely a creation of the Canadian federal state. Although the federal government supported the alternative service-delivery potential of the Independent Living movement, IL changed in Canada into something different from its U.S. parent as a model of service-delivery. Instead, the IL wing of the movement was shaped out of the Canadian disability consumer movement's rights-based consciousness and the federal state's citizenship participation orientation. This resulted in a movement defined, not by its service-delivery origins and goals as in the U.S., but instead by the principles of self-advocacy and citizenship self-determination.

In a study I completed for CAILC in 1994, I detailed the history of the Canadian Independent Living movement and its federal organization, CAILC. ${ }^{25}$ While that historical study centered primarily on the organizational evolution of CAILC, in this study I focus on the character of the relationship between CAILC and the federal government since the mid1980s. In particular, I discuss the formation of the federal Independent Living 
demonstration project (known as the 'Special Initiative') jointly between CAILC, the Secretary of State (SOS) and National Health and Welfare (NHW) in November, 1988. In 1993, when parts of the SOS were integrated into the Department of Human Resources Development Canada, only two of the 'Special Initiative' partners remain-CAILC and HRDC. I have divided this section into two parts: first, I describe the development of the 'Special Initiative', the central roles and responsibilities of the partnership-model and the funding arrangements. In the second part, I undertake an analysis of the partnership, assessing its impact on both the Independent Living movement and the wider Canadian disability movement.

\section{The Historical Development of the Special Initiative Partnership}

In chapter two, I discussed the central influences which contributed to the development of the Independent Living movement in Canada. Here I focus on support for the idea of Independent Living by the federal government which I argue ultimately led to the development of the panCanadian IL movement. It is clear that the single most important element in the development of Independent Living in Canada was the formal endorsement of the idea of IL and the promotion of an Independent Living demonstration project in recommendations 75 and 76 in the 1981 Obstacles report. The Obstacles recommendations read as follows: 
Recommendation 75-Promote Independent Living over Institutionalization: That the Federal government promote a more suitable and cost-effective alternative to institutionalization by introducing enabling legislation for cost-sharing with provinces and municipalities the provision of comprehensive services to assist disabled persons to live and function independently in the community. That the proposed legislation include the following features: (1) Independent Living services to be made available to disabled adults by non-profit organizations which are managed by disabled persons or their representatives; and (2) family support services to be made available on a sliding fee scale to assist families with a disabled dependent.

\section{Recommendation 76--Establish Funds for Demonstration Projects in Independent Living: That the Federal Government, together with the interested provincial governments, make a commitment in 1981 to assist in the funding and establishment of demonstration projects which would provide Independent Living services to disabled persons (Obstacles, 1981a: 148-197).}

In 1982, the Special Committee released a progress report detailing the federal government's (in)actions on each of its 130 recommendations, incluading those associated with Independent Living. The Committee reported that recommendation 75 was under consideration by the government, but conceded that the implementation of federal legislation concerning IL services was not feasible because it was a matter under provincial jurisdiction. It did state, nonetheless, that the federal government should "promote the concept of independent living through whatever means it could, including the use of pilot projects" (Progress Report, 1982: 107). Recommendation 76 dealt with this issue directly and in 1982 the Committee reported that the government had taken no action on its implementation. The Committee's original report, urged the government to utilize funds from the Canada Assistance Plan or the National Welfare Grants Program within NHW for the establishment of an IL demonstration project. Neither option had been chosen by government in 1982, so the Committee expressed its 
"disappointment" and reiterated its original recommendation to the government (Progress Report, 1982: 108). As well, in 1985, the SubCommittee on Equality Rights endorsed the recommendations of the Obstacles report "urg[ing] the Government...to take measures...to implement them without further delay" (Equality for All, 1985: 83).

Although the government had not implemented an Independent Living demonstration project, by the mid-1980s individual Independent Living Resource Centres (ILRCs) were emerging with the support of the Mennonite Central Committee (MCC) and limited provincial grants. At the same time, support for the idea of Independent Living came from the Hon. Walter McLean, Secretary of State under the Mulroney Conservatives. In fact, the first ILRC to open in Canada was in Waterloo, Ontario; Mr. McLean's home riding (Valentine, 1994: 18). By 1985, five ILRCs were operating (or in the development stages) in Waterloo, Winnipeg, Thunder Bay, Calgary and Toronto. There was concern that these Centres, while all espousing the same philosophy, might encounter problems with communication and organizational development at the federal level. As a result, the five existing ILRCs, with the support of the endorsement of the federal government, formed a pan-Canadian organization, CAILC, to represent them federally (Valentine, 1994: 21-23). Limited funding for these fledgling ILRCs and CARC was provided through project grants from DPPP within the SOS and the Health Promotions Branch of NHW.

In 1988, seven years after the Special Committee's recommendation in Obstacles, the federal government established an Independent Living demonstration project known as the 'Special Initiative'. There is no doubt that the recommendations contained in the Obstacles report and subsequent progress reports by the Special Committee on the Disabled and the 
Handicapped throughout the 1980s, contributed to the establishment of the 'Special Initiative' between CAILC, SOS and NHW. The Minister of Health and Welfare announced that the intent of the 'Special Initiative' was to "advance a network of ILRCs in major Canadian Centres and regions" (Canada, National Health and Welfare, Press Release, November 10, 1988). To date, the 'Special Initiative' has provided funding to the Independent Living movement from fiscal year 1988-89 through 1996-97. Funding for the 'Special Initiative' was allocated initially from DPPP in the SOS, as well as the Disabled Persons Unit in NHW. In 1991, however, the 'Special Initiative' was extended for another five years to be funded out of the National Strategy for the Integration of Persons with Disabilities. Below I explore in more detail the parameters of the 'Special Initiative' through an examination of its roles and responsibilities and funding arrangements.

\section{Roles and Responsibilities of the 'Special Initiative'}

A government official remarked that the 'Special Initiative' got underway in "great haste" 26 because there was a window of opportunity to have cabinet approve a federal demonstration project of this nature. As I described in chapter two, in the mid-1980s there was a federal environment receptive to the idea of Independent Living. The government had recently committed $\$ 1$ million to de-institutionalization projects after a federal/provincial/territorial review of social services and the Minister of National Health and Welfare, Jake Epp, was willing to explore and support alternative service-delivery approaches. As a Mennonite, he knew and trusted several key stakeholders in the Canadian Independent Living movement. 
The idea of the Independent Living movement in Canada was (and is) that PWDs are entitled to full citizenship rights including access to resources which enable them to manage their own disability-related services (CAILC, 1994a). Although social services are a provincial, rather than federal area of jurisdiction, the federal government accepted the principles of consumercontrol, self-advocacy and self-determination of disability-related services and chose to support Independent Living as a federal demonstration project. The original intent was that the federal government would foster the idea of Independent Living through the development of a network of ILRCs and CAILC proving to the provinces that this alternate service-delivery approach was viable and cost-effective. This, in turn, would lead provincial governments to 'buy into' the idea of Independent Living at which point, in theory, provincial governments would share the cost for some services offered through ILRCs with the federal government. The original vision was that the federal government would 'kick start' the idea of Independent Living so that it became 'institutionalized' and 'bureaucratized' through a set of community-based disability resource Centres. This would lead the provinces to invest in the idea of Independent Living which ultimately would result in the sustainability of the Independent Living movement through cost-sharing agreements under CAP. As originally conceived, the overall objectives of the 'Special Initiative' were to:

- demonstrate the Independent Living model;

- assist PWDs to integrate and full participate in Canadian society;

- establish a network of 23 ILRC across Canada; and

- secure provincial funding through the Canada Assistance Plan (Towards Independent Living in Canada, 1990: 2-3).

The scenario of cost-sharing with the provinces was only partially realized, however, largely because of the federal government's 'cap on CAP' in 1993, 
and its projected elimination in 1996. In fact, only one ILRC entered into a cost-sharing agreement with the province of Manitoba.

The overall roles and responsibilities of the 'Special Initiative' were concretely defined two years following the establishment of the partnership between SOS, NHW and CAILC in a document entitled, Towards Independent Living in Canada: A Developmental Initiative (1990). This document details the overall mandate of the federal demonstration project and establishes the compendium of tasks around which each of the 'partners' were responsible for both emerging and established ILRCs. I have highlighted these tasks in Table 8.

\section{TABLE 17}

Roles and Responsibilities of the 'Special Initiative' Partners as Defined in the Terms of Reference

\begin{tabular}{|c|c|c|}
\hline & New and Emerging ILRCs & Established ILRCs \\
\hline CAILC & $\begin{array}{l}\text { promote the development of ILRCs } \\
\text { in local communities } \\
\text { assist ILRCs in bringing forward } \\
\text { proposals to the SOS } \\
\text { - assist in the development of ILRCs } \\
\text { (through organizational } \\
\text { strategies, program development) }\end{array}$ & $\begin{array}{l}\text { provide services to member ILRCs } \\
\text { (through organizational develop- } \\
\text { ment, training, consultation, } \\
\text { information exchange) } \\
\text { - assist ILRCs in discussions with the } \\
\text { SOS and NHW } \\
\text { - help improve financial stability of } \\
\text { ILRCs }\end{array}$ \\
\hline SOS & $\begin{array}{l}\text { work with and provide funding to } \\
\text { ILRCs } \\
\text { assist emerging ILRCs move from } \\
\text { the development stage to the stage } \\
\text { of an established ILRC eligible for } \\
\text { NHW (core) funding }\end{array}$ & $\begin{array}{l}\text { active participation on the funding } \\
\text { review committee with CAILC and } \\
\text { NHW } \\
\text { help improve financial stability of } \\
\text { ILRCs }\end{array}$ \\
\hline NHW & $\begin{array}{l}\text { facilitate the development of } \\
\text { ILRCs (through information } \\
\text { sharing, funding review and } \\
\text { feedback) } \\
\text { assist ILRCs in preparation for } \\
\text { NHW core funding }\end{array}$ & $\begin{array}{l}\text { assist the development of ILRC.s } \\
\text { (though provision of funding) } \\
\text { moritor the administration of NHW } \\
\text { core funding through funding review } \\
\text { committee } \\
\text { - help improve financial stability of } \\
\text { ILRCs }\end{array}$ \\
\hline
\end{tabular}

Source: CAILC, NHW, SOS, Towards Independent Living in Canada, 1990. 


\section{Funding Arrangements of the 'Special Initiative'}

The overall funding allocation under the 'Special Initiative' was divided into two separate, yet interrelated parts:

The Secretary of State, through DPPP, provided funding to a limited number of emerging ILRCs. These ILRCs, known as Developing Centres, would be eligible to receive development funding for a maximum period of three years. The first year of funding would be allocated to complete a needs/feasibility study to assess the viability of developing an ILRC in a particular community. Funding over the next two years would be used to implement the results of the study and stabilize the community base for the ILRC. (Towards Independent Living in Canada, 1990: 3).

National Health and Welfare, through the Disabled Persons Unit, provided a total of $\$ 1.5$ million per fiscal year to cover operational costs of selected and established ILRCs. The three partners, NHW, SOS and CAILC, would identify and approve funding through an application process that each ILRC was required to complete (Towards Independent Living in Canada, 1990: 3).

In addition, the process of planning, managing and monitoring the 'Special Initiative' was the responsibility of a joint planning committee comprised of members from each of the partners. The federal government notes, however, in the partnership document that "[f]inal funding decisions....are the exclusive responsibility of the Department affected" (1990: 3).

As I noted above, the original intent of the 'Special Initiative' was to demonstrate the efficacy of the idea of Independent Living to the provinces through the development of the Independent Living movement federally. This, in turn, was to lead to the sustainability of the movement through costsharing agreements via CAP. ${ }^{27}$ The federal funding allocation therefore was developed as a three stage process: 
Stage 1 Development Stage-Secretary of State (feasibility study)

Stage 2 Establishment of Centres-National Health and Welfare (core funding for programs)

Stage 3 Ongoing Operations-Canada Assistance Plan (funding through provincial governments)

For the ILRCs, federal support was provided by the SOS to get the Centres 'off the ground' at which point they would move along the tiered funding model to receive core funding from NHW to establish the core programs and an administrative infrastructure. Finally, in the third stage, the provinces would invest in the infrastructure developed by the federal government through the 'Special Initiative' and cost-share to support the ILRCs. Although plausible, this model ignored the fragmented nature of social services across the country and the inability and/or unwillingness of some provinces to invest in the idea of Independent Living. Moreover, the imposed 'cap on CAP' in some provinces meant that they could not enter into new cost-sharing agreements. These factors meant most ILRC.s did not move to the third stage of the funding model, although many developing II.RCs (funded by the SOS) moved to the second stage (NHW). ${ }^{28}$ This meant most ILRCs received federal funding through the National Health and Weifare section of the 'Special Initiative' which was set at \$1.5 million per fiscal year. In 1988, the NHW funding allocation provided sustaining funds for ten ILRCs and CAILC; in 1996, the number of ILRCs receiving funding through the same allocation had increased to 17 and CAILC (See Appendix B). Barring future negotiations between CAILC and the federal government, this funding arrangement will come to an end in March of 1997.

While the goal of funding model for the ILRCs was a diversified funding base, the national organization, CAILC, has relied completely on 
federal funding. Over the last five years, the 'Special Initiative' funding has accounted for approximately one-half of CAILC's annual budget, the remainder coming from project grants from a variety of federal departments. ${ }^{29}$ Nevertheless, as a result, CAILC, like CCD, is dependent on federal government funding. As the federal representative disability organization CAILC, required the support of the federal government to fulfill its mandated responsibilities under the 'Special Initiative' including: translation and interpretation (bilingual and sign), the presentation of material in alternate formats and the provision of disability-related supports and attendant care to Board members during meetings. Most important, however, were the costs associated with transportation. The geography of Canada presents an obstacle for all federal non-profit organizations. For PWDs, fewer of whom are in paid employment, travel is especially difficult. 30 Without the support of the federal government CAILC could not have held Board of Directors and Executive Committee meetings resulting in the organization having no central decision-making bodies.

The goal of federal support for the Independent Living movement was not to provide funding for the dissemination of disability-related services at the local level. Indeed, the jurisdictional complexity of the Canadian polity makes this difficult because social services are a provincial, rather than federal responsibility. Instead, federal funding was to assist the IL movement, as a collection of pan-Canadian organizations, develop a community-based infrastructure through which services funded from other sources (i.e., federal, provincial, local and private) could be co-ordinated. The objective was to harness the self-knowledge of PWDs through the creation of a disabilityresponse Centres in which they could, among other things, arrange and coordinate service-delivery for individuals. ${ }^{31}$ The idea was that ILRCs would 
deal with the complexity of the Canadian federal state in arranging and coordinating supports and services, rather than the individual. I have shown this arrangement schematically below:

FIGURE 2

Schematic of the Goal of the 'Special Initiative'

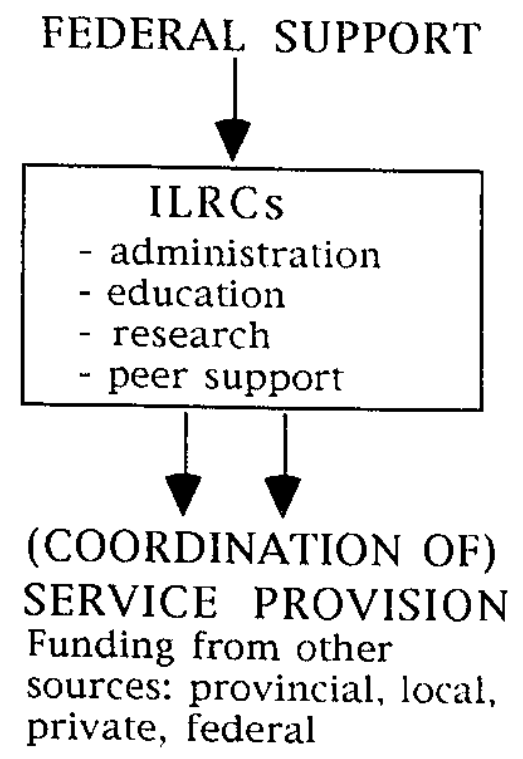

The arrangements of the 'Special Initiative' differ radically from the U.S. model. Because of the nature of the U.S. political system, the federal government has much more direct involvement in the provision of supports and services for PWDs at the state and local levels. In fact, as I discussed in chapter two, the amendments to the federal Rehabilitation Act in 1978 established funding for the Independent Living movement and disabilityrelated services at the local and state levels. The Canadian arrangement, however, provided funding to establish the infrastructure necessary to coordinate services which originated and were funded from other sources. 


\section{Assessing the Partnership-Model of the 'Special Initiative'}

Susan Phillips suggests that the emergence of "strategic partnerships" between the federal government and movement organizations has been used as a tool to ensure that groups have increased accountability to the government, as well as providing the government with a consultative body on policy and program ideas (1991: 205). The term, "partnerships," Phillips continues, "has become the buzzword of the 1990s" (1991: 206). The development of the 'Special Initiative' is an excellent early example of the partnership-model to which Phillips refers. She argues that there are four types of partnership-models:

- Consultative Partnerships refer to institutionalized stakeholder consultations, such as the Round Table on the Economy and the Environment. This type of partnership is simply an up-dated version of government advisory councils.

- Contributory Partnerships are an innovation of the Mulroney government and their primary purpose is to put in place new resources which ultimately will lead to the replacement of government with private sector money. It is a model premised on corporate-group-government partnerships.

- Community Development Partnerships are intended to cultivate human and financial resources at the community-level so that local communities can deliver government policy. The emphasis does not centre on social change, but rather the intent is to de-centralize the process of policy and program formulation and implementation to the community.

- Collaborative Partnerships are said to involve true power-sharing in an attempt to develop broad policy consensus among the partners. In practice, this type of partnership is rare (Phillips, 1991: 206-210).

Using Phillips typology of partnership models, the 'Special Initiative' is best understood as a community development partnership.

The federal government viewed the idea of Independent Living and the development of the Independent Living movement as providing an opportunity to foster the self-sufficiency of PWDs. Leaders in the 
Independent Living movement argue that a central principle of IL. is to "create their own consumer-based methodologies" (CAILC., 1994a). The government interpreted the idea of Independent Living as meaning the end to permanent dependence on the welfare state, through an investment in greater self-sufficiency. In short, Independent Living seemed to present the federal government with the ability to transfer its responsibility for services and programs for PWDs (through cost-sharing) to the provincial/territorial and local levels through a process of federal mentoring via the 'Special Initiative'.

The idea of the 'Special Initiative', from the government's perspective, was to build an alternate community-based service-delivery system which PWDs would be responsible for managing. The ultimate control over the new system (i.e., funding), however, would still remain in the hands of the state (at different levels). Shlomo Hasson and David Ley, in their comparative investigation of neighbourhood organizations and the welfare state, characterize this situation in the following way: "On the one hand, the state appears as centralist and even manipulative, and, on the other, as open to new experiments of decentralization and democratization" (1994: 329). This situation, Hasson and Ley continue, is a "salient feature of neocorporatism, where citizens' groups are allowed a high level of political discretion as long as they follow the prevailing rules of the game" (1994: 329). The consequence is that governments decrease public services while sustaining public consultation. This results in a pattern in which,

the state is apparently seeking to resolve both economic and legitimation crises...to reduce its social expenditures and at the same time to foster political loyalty through collaboration with informal and formal organizations [which can result] in cooptation, bureaucratization, organizational closure, and professional leadership (Hasson and Ley, 1994: 331). 
The 'Special Initiative' directly contributed to the advancement of the Canadian disability movement, while at the same time, fostering the creation of a federally oriented and dependent movement. In my earlier study I found that a majority of the ILRCs surveyed reported that the 'Special Initiative' funding had resulted in a "dependent relationship between the Centres and the funding partners [the federal government]" (Valentine, 1994: 66). There is, however, another, ecually important element of the 'Special Initiative' to consider.

I suggested at the beginning of this section that the Independent Living movement in Canada does not reflect the service-delivery orientation of the U.S. Independent Living movement, but thus far I have not given this particular consideration. While it is the case that some Canadian ILRCs offer a service-delivery component, most do not engage in (hard) service provision. This raises a fundamental contradiction over the goals of the 'Special Initiative' between the federal government and the Independent Living movement. It is clear that the federal government invested in Independent Living and fostered the development of the IL movement because the government believed it would offer an alternative communitybased institutional framework from which disability-related services could be disseminated. Members of the IL movement, especially at CAILC, however, did not see their primary goal as service-delivery; rather they framed their activities within the rubric of citizenship-rights. The activities undertaken by the IL movement have been defined within the parameters of self-advocacy, self-sufficiency and self-determination. ILRCs did not get involved in the dissemination of (hard) services because members of the IL movement believed that the welfare state should provide the funding and frameworks for services. The role of the IL movement was to assist PWDs coordinate and 
manage their services through skills development and peer support. This citizenship orientation is not surprising given the environment, particularly within government, in which Independent Living emerged and developed. In many ways, IL in Canada simply reflects the wider-environment of citizenship development at the federal level in the 1970s and 1980s.

Despite this contradiction, the 'Special Initiative' partnership has been positive for both the federal government and the Independent living movement. First, without federal support, Independent Living would not have developed into a pan-Canadian movement and, second, the federal government supported what was initially an 'ill-defined' partnership, but has since developed into an idea and movement which is now a central component of disability discourse in Canada. Although in the 1990s, federal support for disability initiatives has waned, the government continues to support the principles of the Independent Living movement. Indeed, CAILC. and the ILRCs offer the federal government a proven vehicle to continue the transfer of responsibility for PWDs from the federal to provincial/territorial and local levels of government. The key, however, is to ensure that ILRC.s have sufficient federal funding to maintain their infrastructure in those regions and provinces where geography, climate and population density play are a central factor. Inde, endent Living should not suffer because of factors relating to Canada's vast territory, northern climate or sparse population. The federal government should continue to support, as it has since the late1970s, the infrastructure of Canadian disability movements. 


\section{V \\ Conclusion}

In this chapter I detailed the environment at the federal level since the 1970s and how it affected PWDs using the concept of political opportunity structure. I began by focusing on how movement literature assists us in understanding the activism of PWDs in Canada. In particular, I highlighted the importance of place for disability movements, as well as the central role that the federal state has played for most movements in Canada. I concluded that the disability movement does not represent a form of political activity which is post-modern or post-materialist in orientation, but instead has fostered close ties with governments. Next, I explained the federal government's positive response towards the goals of the Canadian disability movement beginning in the 1980s through a detailed examination of the general thrust of movement activism in the 1970s, the international context, Canadian federal government programs, and the Charter.

In the third section, I surveyed the federal government's response to disability movements since 1980, arguing that government (mostly) responded favourably to disability through policy, programs and provision of funding. I argued further that funding made available through federal citizenship initiatives directly contributed to the development of Canadian disability movements. Without federal support, disability movements could not have developed into federal networks. In the 1970s and 1980s, the federal government had a commitment to citizenship initiatives and through Standing Committee on Human Rights and the Status of Disabled Persons and its predecessors, the Status of Disabled Persons Secretariat, the Disabled Persons Participation Program, and the National Strategy on the Integration of Persons with Disabilities, disability movements developed as federally 
oriented networks. Finally, I suggested that in the 1990s there has been a shift away from the participatory citizenship principles of the 1970s and 1980s, toward an approach focused on economic and employment concerns. Many of the programs which fostered the development of disability movements are under review or slated for elimination. This has left disability movements in a precarious situation.

In the final section, I examined the federal government's support of the Independent Living wing of the disability movement because, while it emerged as an alternate form of service-delivery in the U.S., it developed in Canada through the citizenship orientation of the federal state embracing the principles of self-advocacy and citizenship self-determination. I detailed the evolution of the 'Special Initiative' partnership between CAILC., NHW and the SOS beginning in 1988 which provided sustaining core funds to a network of community-based ILRCs and the national organization. Finally, I suggested, that while the federal government is axing support to other disability movements, it has continued to support the Independent Living movement to date because the idea of II. is premised on individual selfsufficiency. The government views IL as an opportunity to decentralize supports and services for PWDs thereby reducing its responsibility for welfare state services to PWDs. The federal state is implementing its neo-liberal agenda while continuing to cast its initiatives in the norms of citizenship. The idea of Independent Living and the Independent Living movement fit this scenario squarely. 


\section{NOTES}

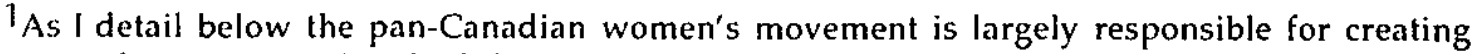
'space' for women within the federal state. The women's movements were successful in getting some of their demands met by the government throughout the 1970s and 1980s. It was women's movements, however, from which the federal government began to withdraw support from first in the late-1980s and 1990s.

2Due to the scope of this problematic, however, I have limited my empirical analysis to the relationship between the Canadian disability movement and the federal state.

3 Sandra Burt has described the difference between role equality and role change in the following manner. Role equality "affects the distribution of men and women in public roles" while role change "affects the definitions of men and women in public roles" (1986: 115). In other words, role equality has its goal in equalizing opportunities between individuals, while role change is concerned with shifting traditional roles so that an individual has both freedom and independence in a variety of contexts.

4These declarations are reprinted in Kallen, (1989): 236-240.

5 It is important to note that Canada seconded the resolution at the United Nations General Assembly to designate 1981 as the International Year of Disab!ed Persons.

6 For a rich discussion on the meanings and experiences of disablement in both the first and the third worlds, see, Benedicte Ingstad and Susan Reynolds Whyte, (eds), Disability and Culture, (Berkeley: University of California Press, 1995).

7For a more comprehensive examination of Disabled Persons International, see, Driedger, (1989). See also, Cherie S. Lewis, "International Aspects of the Disability Issue," Jack A. Nelson, (ed), The Disabled, the Media, and the Information Age, (Westport, Connecticut: Greenwood Press, 1994).

8 The disability groups responsible for arguing that Section 15 should be expanded to include disabled persons are: the Coalition of Provincial Organizations of the Handicapped (COPOH), the Canadian Association for the Nantally Retarded (CAMR), and the Canadian National Institute for the Blind (CNIB). Organizations which supported its expansion included: the Canadian Labour Congress (CLC), the Royal Canadian Legion, the Canadian Human Rights Commission and the Canadian Jewish Congress (Gadacz, 1994: 215).

9 For a more detailed discussion on the composition and role of Parliamentary Committees, see Robert Jackson et. al., Politics in Canada, 2nd ed, (Scarborough: Prentice-Hall, 1990): 344-353.

10The members of the Special Committee in 1980 were as follows: David Smith (chair), Thérèse Killens (vice-chair), Walter Dinsdale (vice-chair), Peter Lang, Bruce Halliday, Stanley Hudecki and Neil Young.

${ }^{1}$ The follow-up report offered a series of twelve recommendations and concluded that existing government initiatives aimed at First Nations peoples had not necessarily helped those First Nations peoples with disabilities. The second part of the report argued that only a 
comprehensive understanding of the history, values and perceptions of Aboriginal peoples would ensure that service programs were effective and productive. See, Canada, speciat Committee on the Disabled and the Handicapped, Follow-Up Report, (Ottawa: Supply and Services, 1981).

${ }^{12}$ Leslie Pal has detailed the organizational and administrative changes which occurred within the SOS through the 1980s. Although the citizenship 'sectors' or 'programs' moved from one section of the department to another, the citizenship participatory focus for disadvantaged groups was constant throughout this period. See, Pal, (1993): 127.

${ }^{13}$ The Standing Committee's most recent report, The Grand Design: Achieving an 'Open House' Vision (1995) is the only Parliamentary Committee report to receive unanimous consent by all federal political parties (Liberal, Bloc Quebécois and Reform) since the formation of the $35 \mathrm{th}$ Parliament in 1993.

${ }^{14}$ Governments have attempted to provide support for PWDs to gain entry into the job market through vocational rehabilitation services as legislated by the Vocalionml Relumbilitution of Disabled Persons Act (VRDP). This Act established a federal program designed to prov: de funds to provincial/territorial governments ( $50 \%$ of the funds incurred) for programs which are intended to integrate PWDs in training and employment programs. Despite its intent, some aspects of VRDP have been criticized as outdated and laden with barriers and cligibility criteria which are not flexible enough to meet contemporary realities. In February of 1995, the federal government initiated a process of reforming employment initiatives under VRDP in an attempt to create new and cost-effective models for Canadians with disabilities. These reforms remain undefined.

15The Parliamentary Committee on Equality Rights was a sub-committee of the standing Committee on Justice and Legal Affairs.

16It is important to note that since the Speech from the Throne in 1986, successive Ministers of Justice have affirmed the government's intention to amend the Camadian Humam Rights A A t as recommended by the report of the Sub-Committee on Equality Rights, Equality for All (1985). Since 1988, this commitment has detailed that the government could amend the Ac $\%$ and include the term of 'reasonable accommodation'. For persons with disabilities, this would remove the employer's capacity to refuse to adjust a job to suit the skills and experience of a qualified employee who has a disability. For more information, see, Gadacz, (1994): 224-231.

17 More specifically, the legislation requires all federally-regulated businesses with over 100 employees to file annual reports beginning in June of 1988 regarding their employment of PWDs, as one of four target groups.

${ }^{18}$ The first Minister Responsible for the Status of Disabled Persons was Benoit Bouchard.

${ }^{19}$ The Canada Assistance Plan (CAP) is a major piece of federal legislation under which social assistance (or welfare) and social services are supported. CAP was introduced in 1966 as a comprehensive plan that replaced several pieces of existing legislation. Under CAP, provinces and territories are responsible for the design and delivery of welfare and social services, but provisions in the legislation allow for the federal government to share with the provinces and territories $50 \%$ of the costs of financial and social services for Canadians. For a greater discussion on CAP as it affects PWDs, see, Roeher Institute, Direct Dollars, (North York: Roeher Institute,1993); CAILC, A Time for Change (Ottawa: CAlLC, 1994). 
${ }^{20}$ According to a program evaluation of DPPP conducted by Price Waterhouse, the average grant to disability consumer organizations amounted to $\$ 17,255$. See, Price Waterhouse, Secretary of State: Evaluation of the Disabled Persons Participation Program. Final Report, (Ottawa: Price Waterhouse, 1991): 22.

${ }^{21}$ As Phillips notes, the Mulroney Conservatives cut funding to groups by $20 \%$ over two years in 1992 and in April of 1993 a further 15\% in each of the next two years and finally an additional $20 \%$ in years subsequent. The Chretien government announced in its 1994 federal budget that the government would impose a $20 \%$ across the board cut to grants extended to groups. See, Phillips, (1994).

22The departments involved included parts of the Secretary of State and the Department of Health and Welfare, the Departments of Labour and Employment and Immigration Canada.

23 It is important to note that in November, 1995, the then-Minister of Human Resource Development Canada, Lloyd Axworthy, reported to the Standing Committee on Human Rights and the Status of Disabled Persons that the federal government would retain VRDP, but with some changes, as a cost-shared program. Discussion between the federal, provincial and territorial governments were to begin to discuss the parameters of a "refocused VRDP." To date, the future of this program remains unclear.

24 It is important to note that I had access to more information than I could present in this investigation. Upon consultation with staff at CAILC, 1 have been directed not to detail some elements of the internal workings of the national organization and its relationship with the federal government. I do not believe this compromises my study in any way, but rather protects the interests of the Canadian Independent Living movement and its supporters.

${ }^{25}$ See, Valentine, (1994).

26 Personal communication. February 21, 1996.

27In March, 1992, the Cost Shared Programs Direcorate of the Social Service Programs Branch of Health and Welfare Canada released a document detailing the way in which the programs offered in each of the ILRCs were applicable under cost-sharing agreements. The documents states that, "|p|rograms offered by IL|R|Cs are shareable under the 'welfare services' component of CAP." See, Canada, Health and Welfare Canada, "Criteria for Sharing under the Canada Assistance Plan in Provincial Costs Related to Independent Living Centres," 1992.

${ }^{28}$ The Independent Living Resource Centre in Winnipeg received formal approval from the Ministry of Family Services in April, 1994, to fund two-thirds of the core programs offered at the ILRC. Nonetheless, the agreement was subject to on-going CAP cost-sharing with the federal government which in April, 1996 ended with the elimination of CAP.

29 In an earlier study, 1 detailed the federal projects undertaken by CAILC. See, Valentine, (1994): 39-44.

30 It was only in 1980 , from pressure by disability movements, that Canada's national public transportation systems began the process of becoming fully accessible for people with various disabilities. 
${ }^{31}$ This idea is similar to the impetus for the creation of women's centres across the country which were funded by the federal government. 


\section{CONCLUSION}

\section{DISABILITY MOVEMENTS, THE CANADIAN FEDERAL STATE AND THE FUTURE}

I

\section{An Overview of the Investigation}

People with disabilities and their movements have been little studied in the social sciences. In this investigation I had two broad objectives: first, to begin the process of redressing the absence of scholarly material within movement analyses on issues relating to disability movements in Canada; second, to disprove the widely-held view that PWDs are passive, 'sick' and politically inactive. In other words, I was interested in challenging the normative belief that PWDs are "non-human" (Noël, 1994) and therefore, not politically active as citizens in the contemporary welfare state. This study did not constitute an investigation of the relationship between PWDs and the medical community. Instead, it addressed a much more profound question; that is, the relationship PWDs have to the Canadian polity and to state institutions as autonomous political actors. To accomplish this task, I focused on a central wing of the Canadian disability movement and its national organization--the Independent Living movement and the Canadian Association of Independent Living Ceritres (CAILC).

In chapter one, I highlighted the fact that there is little material examining PWDs as autonomous political actors because most academic knowledge systems have approached the issue and experience(s) of disablement as individualized and medicalized. The meaning and experience(s) of disablement have been influenced by medical and social 
science research, political philosophy, and the contemporary welfare state. I showed how PWDs have fundamentally challenged these normative understandings of contemporary citizenship and identity politics through the movements they organized on their own behalf beginning in the 1970s.

In particular, I showed how PWDs rejected their dependent position within the contemporary welfare state and began to re-interpret the meaning and experience(s) of disablement. Indeed, the pressure to reconceptualize disablement in a social rather than individual manner comes from both the Canadian disability consumer movement and the Independent Living movement. Concepts such as 'cross-disability' have challenged the individualized pathology of modern medicine, social science research and the administrative frameworks of the contemporary welfare state because this process of 're-naming' brings persons with all types of disabilities (physical and/or mental) to form a collective disability identity. As well, the concept of 'cross-disability' successfully widens disability-discourse to a consideration of how disablement intersects with factors such as race, class, sex/gender, sexual orientation and geographic location/climate.

In chapter two, I turned to a discussion of the history, structure and diffusion of disability movements in Canada. I focused on the choices and strategies Canadian disability movements implemented throughout the 1970s and 1980s, arguing that the political environments in which movements emerge and develop significantly affect their structure, orientation and strategies. In Canada, this is particularly evident at the federal level. To that end, I detailed the way in which the Canadian Independent Living movement, as an organizational body and political strategy 'invented' in the United States, changed when it was transplanted to Canada, a country with a profoundly different political culture and political opportunity structure. 
Finally, in chapter three, I explored the character of the relationship between the Canadian federal state and disability movements since the 1970 using the concept of political opportunity structure to frame my discussion. I argued that, while the Canadian federal state has been receptive to the demands of disability movements beginning in the 1980s, the retrenchment of the contemporary welfare state in the 1990s is threatening the citizenship goals of disability movements. Despite the "hollowing out" (Brodie, 1996) of the welfare state, the federal government continues to support the Canadian Independent Living movement. My study of the relationship between the federal state and the Canadian Independent Living movement revealed that the state fostered the idea of Independent Living and developed the Independent Living movement largely through citizenship initiatives within the federal bureaucracy. It is the potential for devolving service-delivery from the federal to the provincial/territorial and local levels which the state finds appealing in IL in this of neo-liberal era.

\section{II}

\section{Key Findings of the Investigation}

There is little Canadian material which attempts to account for disability movement activity from a 'grounded' Canadian perspective, since most scholars rely on imported U.S. or European frameworks. My analysis of Canadian disability movements was framed within "Canadian realities" (Vickers, 1995) and points to the fact that disability movements, unlike many other movements (i.e., women, peace, ecological), are genuinely 'new', emerging only in the post-World War II period. In other words, disability movements did not have an 'older' wave of organizing. Perhaps the only other movement that can be considered 'new' are gay/lesbian liberation 
movements, which emerged, like disability movements, only in the postWorld War II period. The six key findings of this study are detailed below:

\section{People with Disabilities are political actors, but they cannot be so at the federal level without support from the government.}

This investigation showed that the self-knowledge of PWDs has been largely ignored and undervalued by academic disciplines and fields. As a result, I made the self-knowledge of PWDs central, through an examination of their movements and showed how disability movements have challenged the normative understandings of disablement which are premised on the notion that PWDs are 'sick', passive, imperfect and incomplete human beings. By focusing on the self-knowledge of PWDs, I have shown that they are active political agents with full entitlements to citizenship rights.

PWDs created their own organizations at the local, provincial and federal levels beginning in the 1970s to assert their self-knowledge and influence towards organizations, institutions and/or government. Nonetheless, to assert full citizenship rights, PWDs require the support of government. Since emerging, Canadian disability movements have received support from the federal government through the Secretary of State and other federal departments. In particular, the Canadian Independent Living movement developed into a pan-Canadian network because of the support it received from the federal government through the 'Special Initiative'. I argued that Canada's vast territory, northern climate and sparse population mean that PWDs and their organizations require federal support. In short, without federal funding, disability movements would not have developed into pan-Canadian networks. 


\section{Pan-Canadian disability movements, especially the Independent Living movement, were fostered by the federal state.}

Throughout the 1970s and 1980s, the Citizenship and Social Action Branches of the Secretary of State have been important factors to the development of disability movements in Canada. As this study showed, the core and project funding provided for disability self-organizations from programs within the SOS provided a stimulus for the development and expansion of Canadian disability movements. In particular, the citizenship participation focus of the SOS during this period has heavily influenced the focus and path of disability movements. The Canadian Independent Living movement, for instance, does not reflect the (hard) service-provision origins of the U.S. movement, in part, because much of its funding came from citizenship initiatives.

As well, the federal state fostered the development of Canadian disability movements through the activist-based Standing Committee on Human Rights and the Status of Disabled Persons and its predecessors. As this study has shown, beginning in the early-1980s, the Standing Committee has played an important and central role in advancing the goals of Canadian disability movements through federal policy, programs and funding allocations to disability initiatives. Of particular importance were: the Status of Disabled Persons Secretariat (established in 1985), the Disabled Persons Participation Program (established in 1985) and the National Strategy for the Integration of Persons with Disabilities (established in 1991). All were administered through the Citizenship Development Branch of the Secretary of State.

The development of the pan-Canadian Independent Living movement and its federal organization, CAILC, have been because of federal initiatives. 
Indeed, Independent Living has been an initiative, rather than a response, of the federal government. The idea for Independent Living at the federal level, while 'invented' in the U.S. and adopted by the existing consumer disability movement, was first elaborated in the Obstacles report (1981a) and was fostered through the establishment of the 'Special Initiative' partnership between CAILC, National Health and Welfare and the Secretary of State beginning in 1988. Without the support offered to CAILC and selected ILRC.s through the 'Special Initiative', the Independent Living movement would not have developed into a pan-Canadian network.

\section{The state-focused orientation of Canadian disability movements was positive for their development.}

I argued that Canadian disability movements are not and cannot be counter-hegemonic and anti-state in orientation partly because they require the provision of state supports and services for their existence and partly because Canadian political culture was defined by "radical liberalism" (Vickers, 1992). This investigation showed that disability movements in Canada, unlike in the U.S., are pro-statist and state-focused. Furthermore, the state-focused orientation of Canadian disability movements has been positive. State support has fostered the development of disability selforganizations which would otherwise not have been able to emerge. Moreover, despite its pro-statist stance, disability organizations have been quite 'radical'. This investigation showed that while the Independent Living movement does not seek a revolutionizing of democracy or capitalism, it does assume a radical stance in its challenge to medical and social service institutions. The movement rejects the stigmatizing roles assigned to them through the medical model of disease and stresses the process of 'normalization', deinstitutionalization, and integration. The primary role of 
professionals is rejected and instead the self-knowledge of PWDs is advanced enabling them to see their own potential, exercise their own choices and participate fully in their own lives.

4. The process of de-institutionalization of individuals has turned out to be more difficult than first anticipated.

Disability movements advocated for a move away from institutional living towards community-based alternatives for PWDs. Beginning in the 1980s, the federal government and some provincial governments began to support the idea of de-institutionalization for PWDs and their integration and participation into community life. Independent Living is an excellent example of a key federal government initiative to support the idea of deinstitutionalization. Indeed, the idea of the Independent Living movement was to foster the development of an alternative set of community-based disability response centres at the local level to assist and support PWDs. Both the federal government and CAILC, however, have come to realize that the process of de-institutionalization is difficult due to the complexity of the contemporary welfare state, Canada's vast territory, northern climate and perhaps most important, sparse population.

\section{Federalism, as well as Canada's geography, territory, climate and sparse population impact disability movements.}

This investigation emphasized the importance of place by focusing on the impact different states have in shaping disability movements. I showed that disability movements do not take a common form globally, but instead are influenced by political, economic and cultural factors. The comparative study of Independent Living in the United States and Canada revealed important differences between these two seemingly similar disability movements. Perhaps most important, however, this study also showed the 
central role that space/territory play in contributing to the construction of Canadian identities, as well as to the material experience(s) of Canadians. This is particularly important for PWDs and their self-organizations. Canada is a vast federal state which is geographically northern and sparsely populated. These elements are particular to the Canadian experience and have directly impacted the type, level, organizational structure and orientation of disability movements in Canada.

\section{Neo-liberalism and the process of de-centralization are significantly different.}

This study points to the radical shift which Canadian federalism is undergoing in the 1990s and its potential impact on PWDs and Canadian disability movements. Most important, however, is that this study highlights the need to make a clear distinction between the norms of neo-liberalism and the process of de-centralization, particularly as they relate to PWDs. The need for a clear distinction is evident in the analysis I presented on the Canadian Independent Living movement.

I detailed the parameters of the 'Special Initiative' between CAILC, SOS and NHW through a consideration of 'partnership' discourse and concluded that while the 'Special Initiative' was a partnership (of sorts) between the federal government and a collection of interrelated non-profit organizations, ultimately the government entered into a demonstration project further to devolve its responsibilities to the provincial/territorial and local level. Decentralization, may, in fact, be a positive development for PWDs and their organizations. Simply because supports and services at the federal level are devolved to other levels, does not mean that similar or better suited supports and services will not be offered by the local level. In fact, local levels of 
government are perhaps better positioned to offer services which directly respond to the particular concerns in that region.

This is the idea behind the federal government's support towards the Independent Living movement. The government fostered the development of a community-based infrastructure in which other funding mechanisms (at whatever level) could invest to offer supports and services to PWDs. In other words, Independent Living represents a way to end, what PWDs thought was a permanent relationship with the federal state. Indeed, the government saw IL as an investment in the self-sufficiency of PWDs through the development of government funded community-based, disability-related supports. This explains, therefore, the continued federal investment in the Independent Living movement when support to most other voluntary sectors (women's, visible minority) is being significantly reduced.

Although the process of state-supported de-centralization has validity for PWDs and their movements, the future of disability organizing is uncertain. The federal state's abandonment of the Keynesian welfare state and its growing replacement with the norms of neo-liberalism will most certainly have a negative effect of PWDs and their movements. As this study showed, neo-liberalism operates from a different set of assumptions about the role of government and the rights of citizens (Brodie, 1996, 4). Indeed, while the Keynesian welfare state embraced the development of a comprehensive social-welfare system, advanced the use of macro-economic levers to control inflation and protect the domestic economy and implemented a liberalized trading philosophy, neo-liberalism attempts to maximize exports, reduce social spending, curtail economic regulation and enable the restructuring of the economy through market-forces (Brodie, 1996). For PWDs and their movements, neo-liberalism is replacing the citizenship focus of the federal 
state with fiscal constraint and employability. Most important, however, is the state's growing abandonment of support for disability movements, which I have argued they require to maintain pan-Canadian networks.

\section{III}

\section{Suggestions for Future Research}

This study has raised and left unanswered many questions. Indeed, the undertheorization of disablement and disability movements means that there is an entire field to explore and uncover. Of importance, however, is the respect which scholars must accord to the self-knowledge of PWDs. For too long, the capacity of PWDs as thinking and feeling beings has been ignored or overlooked. I believe that there are two areas which deserve further attention.

Canadian scholars must pay more attention to the importance of place/territory when theorizing about movement activity. Significant comparative research could be undertaken about how place affects the mobilization of movements. If the findings of this study are any indicator, this is particularly true of disability movements. The difference in movement activity between hot and cold climates, for instance, would prove an interesting investigation. As well, there is a dearth of material comparing movements in the same jurisdiction. Throughout this study, I used the panCanadian women's movement as a comparative tool. There is a need for investigations which concretely document the similarities and differences among movements. 


\section{APPENDIX A}

\section{INDEPENDENT LIVING CENTRE MODEL}

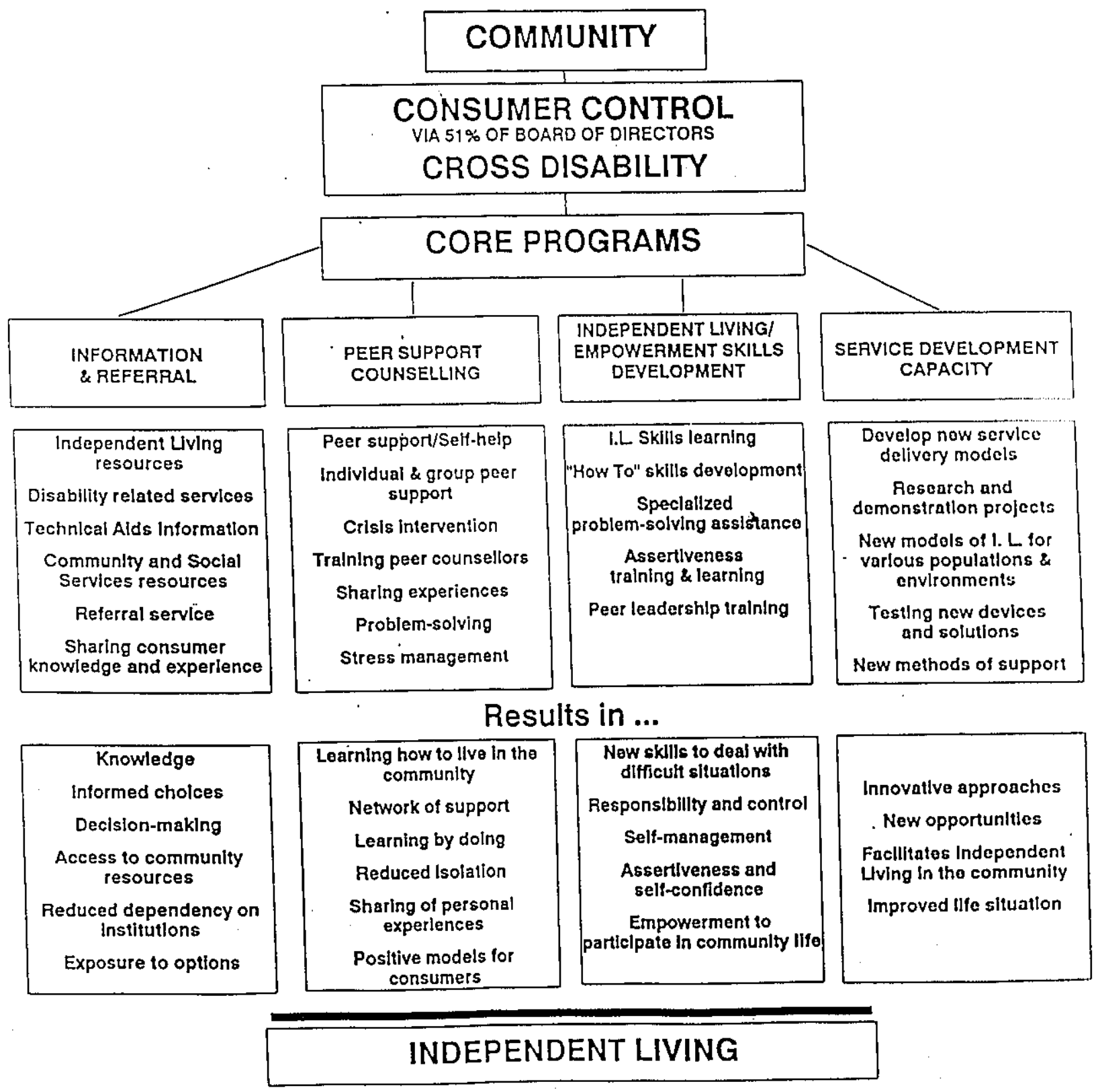




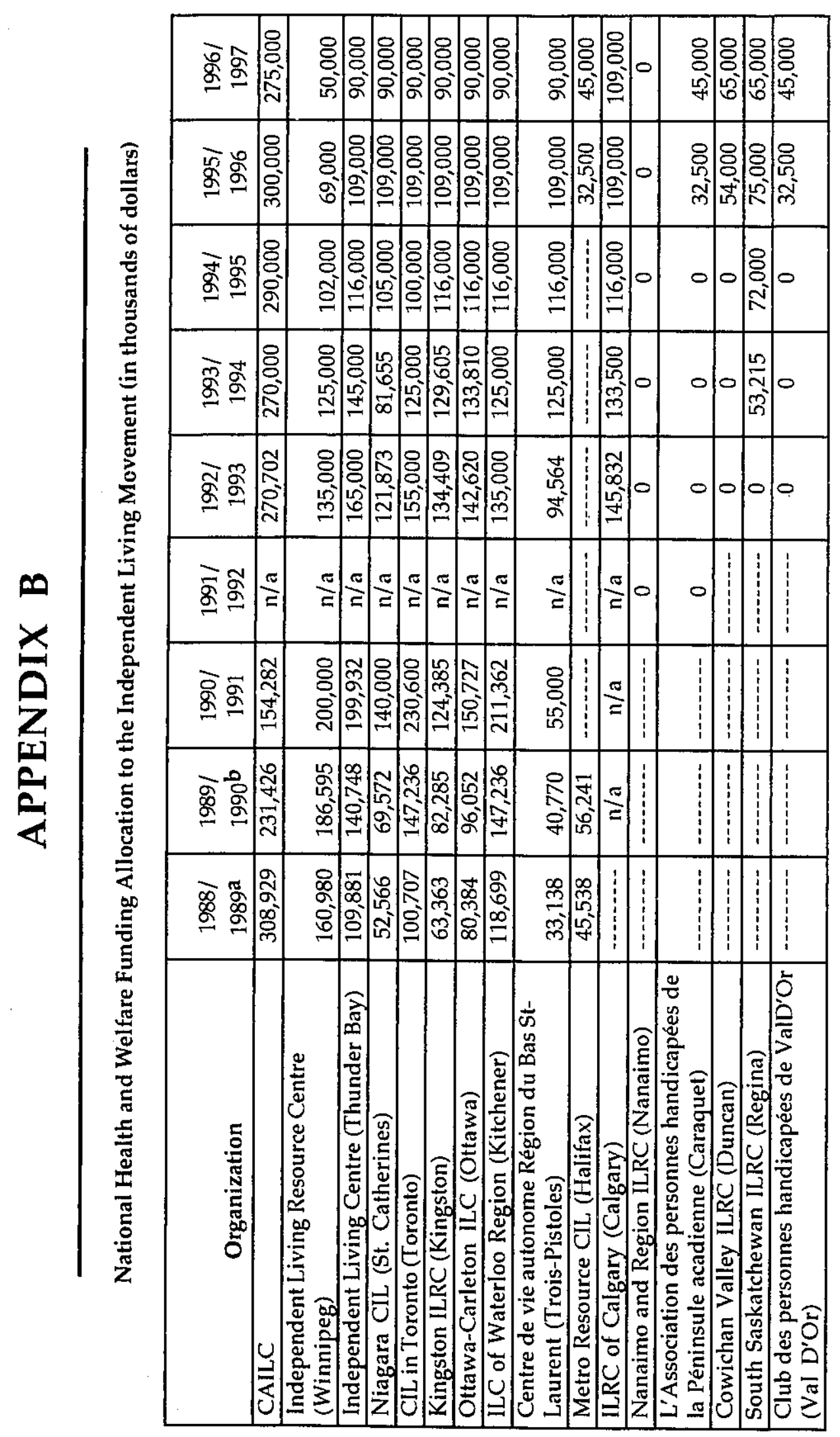




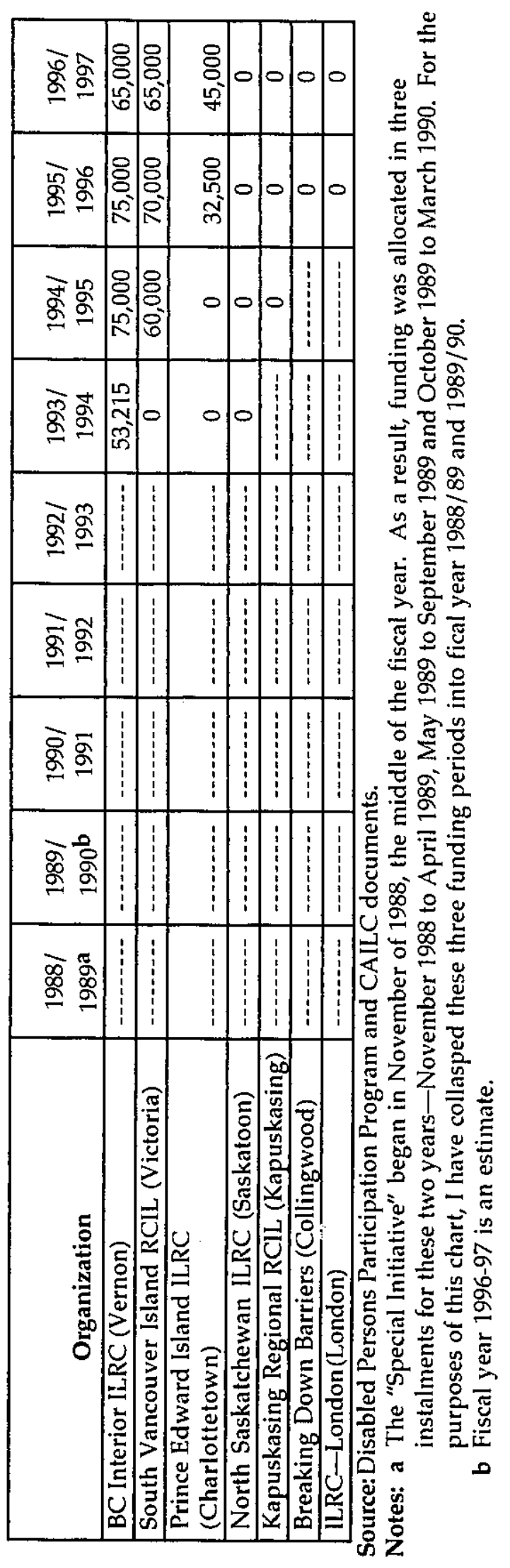




\section{BIBLIOGRAPHY}

Adam, Barry D. 1993. "Post-Marxism and the new social movements," Canadian Review of Sociology and Anthropology. 30 3: 316-36

Adamson, Nancy, Linda Briskin and Margaret McPhail, eds. 1988. Feminist Organizing for Change: The Contemporary Women's Movement in Canada. Toronto: Oxford University Press

Albrecht, Gary L. 1992. The Disability Business: Rehabilitation in America. New York: Sage Publications

Allen, Richard. 1973. The Social Passion: Religion and Social Reform in Canada, 1914-1928. Toronto: University of Toronto Press

Andrew, Caroline. 1984. "Women and the Welfare State," Canadian Journal of Political Science. 27, 4 (December): 667-683

Anspach, Renee R. 1979. "From Stigma to Identity Politics: Political Activism Among the Physically Disabled and Former Mental Patients," Social Science and Medicine. 13A: 765-773

Ball, Christine. 1994. "The History of the Voice of Women." PhD dissertation, Ontario Institute for Studies in Education, Toronto, Ontario

Banting, Keith. 1987. The Welfare State and Canadian Federalism. 2nd ed. Kingston: McGill-Queens University Press

Bashevkin, Sylvia. 1994. "Confronting Neo-Conservatism: Anglo-American Women's Movements Under Thatcher, Reagan and Mulroney," International Political Science Review. 15, 3 (July)

Becker, Howard. 1963. Outsiders: Studies in the Sociology of Deviance. New York: Free Press

Bégin, Monique. 1992. “The Royal Commission on the Status of Women in Canada: Twenty Years Later." In Constance Backhouse and David H. Flaherty, eds., Challenging Times: The Women's Movement in Canada and the United States. Kingston: McGill-Queen's University Press

Berger, T.R. 1981. Fragile Freedoms: Human Rights and Dissent in Canada. Toronto: Clarke Irwin 
Bickenbach, Jerome E. 1991. "AIDS and Disability." In Christine Overall and William P. Zion, eds., Perspectives on AIDS: Ethical and Social Issues. Toronto: Oxford University Press

- 1993. Physical Disability and Social Policy. Toronto: University of Toronto Press.

Boggs, Carl. 1986. Social Movements and Political Power: Emerging Forms of Radicalism in the West. Philadelphia: Temple University Press

Boldt, Menno. 1993. Surviving As Indians. Toronto: University of Toronto Press

Brisenden, Simon. 1986. "Independent Living and the Medical Model of Disability." Disability, Handicap and Society. 1,2

Brodie, Janine. 1996. “Canadian Women, Changing State Forms, and Public Policy." In Janine Brodie, ed., Women and Canadian Public Policy. Toronto: Harcourt Brace \& Company

Brydon-Miller, Mary. 1993. "Breaking Down Barriers: Accessibility SelfAdvocacy in the Disabled Community." In Peter Park, Mary BrydonMiller, Budd Hall and Ted Jackson, eds., Voices of Change: Participatory Research in the United States and Canada. Toronto: OISE Press

Burt, Sandra. 1986. "Women's Issues and the Women's Movement in Canada Since 1970." In Alan Cairns and Cynthia Williams, eds., The Politics of Gender, Ethnicity and Language in Canada. Royal Commission on the Economic Union and Development Prospects for Canada. Toronto: University of Toronto Press

Cairns, Alan C. 1995. "The Embedded State: State-Society Relations in Canada." In Douglas E. Williams, ed., Reconfigurations: Canadian Citizenship \& Constitutional Change. Toronto: McClelland \& Stewart

Cairns, Alan C and Cynthia Williams. 1985. "Constitutionalism, Citizenship and Society in Canada." In Alan Cairns and Cynthia Williams, eds., Constitutionalism, Citizenship and Society in Canada. The Royal Commission on Economic Union and Trade Development Prospects for Canada. Toronto: University of Toronto Press

Canada. Health and Welfare. 1975-1993. Annual Reports. Ottawa: Supply and Services 
- Health and Welfare. 1992. "Criteria for Sharing Under the Canada Assistance Plan in Provincial Costs Related to Independent Living Centres." (March)

—. Human Resources Development Canada. 1994-1996. Annual Reports. Ottawa: Supply and Services

- Human Resources Development Canada. 1994. Improving Social Security in Canada: A Discussion Paper. Ottawa: Supply and Services

- Human Resources Development Canada. 1995. "Notes for an address by the Honourable Lloyd Axworthy, Minister of Human Resources Development and Minister of Western Economic Diversification." Appearance before the Standing Committee on Human Rights and the Status of Disabled Persons, (November 9)

- Secretary of State. 1975-1993. Annual Reports. Ottawa: Supply and Services

—. Secretary of State. Program Evaluation Directorate. 1986. A Framework for Cross-Sectoral Evaluation of Core Funding in the Secretary of State. Ottawa: Supply and Services. (March)

- Secretary of State. 1988. Grants and Contributions Manual. Ottawa: Supply and Services

- Secretary of State. 1991. The National Strategy for the Integration of Persons with Disabilities. Ottawa: Supply and Services

- Special Parliamentary Committee on the Disabled and the Handicapped. 1981a. Obstacles. Ottawa: Supply and Services

- Special Parliamentary Committee on the Disabled and the Handicapped. 1981b. Obstacles: Follow-Up Report. Ottawa: Supply and Services

- Special Parliamentary Committee on the Disabled and the Handicapped. 1982. Progress Report to Obstacles. Ottawa: Supply and Services

- Special Parliamentary Sub-Committee on the Disabled and the Handicapped. 1987. Challenge: Putting Our House in Order. Ottawa: Supply and Services 
- Special Parliamentary Sub-Committee on the Disabled and the Handicapped. 1988. No News is Good News. Ottawa: Supply and Services

- Standing Committee on Human Rights and the Status of Disabled Persons. 1990. A Consensus for Action: The Economic Integration of Disabled Persons. Ottawa: Supply and Services

- Standing Committee on Human Rights and the Status of Disabled Persons. 1990. Unanswered Questions. Ottawa: Supply and Services

- Standing Committee on Human Rights and the Status of Disabled Persons. 1990. Minutes of Proceedings and Evidence. 34 (September 28). Ottawa: House of Commons

- Standing Committee on Human Rights and the Status of Disabled Persons. 1990. Minutes of Proceedings and Evidence. 16 (February 6).

Ottawa: House of Commons

- Standing Committee on H:uman Rights and the Status of Disabled Persons. 1993. Minutes of Proceedings and Evidence. 32 (June 8).

Ottawa: House of Commons

- Standing Committee on Human Rights and the Status of Disabled Persons. 1994. Minutes of Proceedings and Evidence. 6 (April 26). Ottawa: House of Commons

- Standing Committee on Human Rights and the Status of Disabled Persons. 1994. Minutes of Proceedings and Evidence. 9 (May 24).

Ottawa: House of Commons

- Standing Committee on Human Resources Development. 1995. Security, Opportunities and Fairness: Canadians revewing their social programs. Ottawa: Supply and Services

- Standing Committee on Human Rights and the Status of Disabled Persons. 1995. The Grand Design: Achieving an 'Open House' Vision. Ottawa: Canada Communications Group

- Statistics Canada. 1988. The Health and Activity Limitation Survey (HALS)_Users Guide. Ottawa: Statistics Canada

- Sub-Committee on Equality Rights. of the Standing Committee on Justice and Legal Affairs 1985. Equality For All. Ottawa: Queen's Printer 
—. Task Force on Program Review. 1985. Culture and Communications. Ottawa: Supply and Services

- Task Force on Program Review. 1985. Citizenship, Labour and Immigration: A Plethora of "People" Programs. Ottawa: Supply and Services

- Treasury Board. 1980-1993. Department of the Secretary of Canada. The Estimates, Part III. Ottawa: Supply and Services

- Treasury Board. 1980-1993. Department of National Health and Welfare. The Estimates, Part III. Ottawa: Supply and Services

- Treasury Board. 1994-1996. Department of Human Resources Development. The Estimates, Part III. Ottawa: Supply and Services

- Vetrans Affairs. 1988. Vetrans Affairs Annual Report, 1987-88. Ottawa: Supply and Services

Canadian Association of Independent Living Centres. 1986-1995. Annual Reports. Ottawa: CAILC.

- 1986-1995. Annual General Meeting Reports

-1986-1995. Board of Directors Minutes

-1987-1995. CAILC Newsletters

—. 1989a. Eligibility Criteria for CAILC Membership. Ottawa: CAILC

—. 1989b. Independent Living Promotion Kit. Ottawa: CAILC

-1992. Description of the Core Programs of Independent Living Centres. Ottawa: CAILC

- 1990. Towards Independent Living in Canada: A Developmental Initiative. Ottawa: CAILC

- 1994a. A Time for Change, the Time for Choices: A Proposal for Improving Social Security Arrangements for Canadians with Disabilities. Ottawa: CAILC

- 1994b. Choice, Flexibility and Control in Community Research: A Guidebook. Ottawa: CAILC

- 1995. National Directory of ILRCs. Ottawa: CAILC 
Canel, Eduardo. 1992. "New Social Movement Theory and Resource Mobilization: The Need for Integration." In William Carroll, ed. Organizing Dissent: Contemporary Social Movements in Theory and Practice. Victoria: Garamond

Carpenter, Sandra. 1991. “Disability: Towards the Transparent," FUSE. 143 (Winter): $23-30$

Carroll, William K. ed. 1992. Organizing Dissent: Contemporary Social Movements in Theory and Practice. Victoria: Garamond Press

Cavell, Richard A. 1994. "Theorizing Canadian Space: Postcolonial Articulations." In Terry Goldie, Carr:en Lambert and Rowland Lorimer, eds., Canada: Theoretical Discourse/Discours théoriques. Montréal: Association for Canadian Studies/Association d'études canadiennes

Coalition of Provincial Organizations of the Handicapped/Council of Canadians with Disabilities. 1980-1995. Annual Reports. Winnipeg: $\mathrm{COPOH} / \mathrm{CCD}$

Crewe, Nancy M., Irving Kenneth Zola and Associates, eds. 1983. Independent Living for Physically Disabled People. Washington: Jossey-Bass Publishers

Cunningham, Frank, Sue Findlay, Marlene Kadar, Alan Lennon and Ed Silva, eds. 1988. Social Movements/Social Change: The Politics and Practice of Organizing. Toronto: Between the Lines

Dale, Jennifer and Peggy Foster. 1986. Feminists and State Welfare. London: Routledge \& Keagan Paul

Dalton, Russell J., Manfred Keuchler and Wilhelm Burklin, eds. 1990. Challenging the Political Order. London: Polity Press

Darnovsky, Marcy, Barbara Epstein, and Richard Flacks, eds. 1995. Cultural Politics and Social Movements. Philadelphia: Temple University Press

Davis, Lennard J. 1995. Enforcing Normalcy: Disability, Deafness and the Body. New York: Verso

DeJong, Gerben. 1979. "Independent Living: From Social Movement to Analytic Paradigm," Archives of Physical Medicing and Rehabilitation. 60, 10 (October): $435-46$ 
-. 1983. "Defining and Implementing the Independent Living Concept." In Nancy Crewe, Irving Kenneth Zola and Associates, eds., Independent Living for the Physically Disabled. Washington: JosseyBrass Publishers

Dejong, Gerben and Raymond Lifchez. 1983. "Physical Disability and Public Policy." Scientific American. 248, 6: 40-9

DeLoach, Charlene, Ronnie D. Wilkins and Guy W. Walker, eds. 1983. Independent Living: Philosophy, Process and Services. Baltimore: University Park Press

Demas, Doreen, ed. 1993. Access to the Sweet Grass Trail. Winnipeg: Coalition of Provincial Organizations of the Handicapped

Dodge, William. 1992. Boundaries of Identity: A Quebec Reader. Toronto: Lester Publishing

Doucette, Joanne. 1991. “The DisAbled Women's Network: A Fragile Success." In Jeri Dawn Wine and Janice L. Ristock, eds., Women and Social Change: Feminist Activism in Canada. Toronto: Lorimer

Driedger, Diane. 1984. "The Struggle for Legitimacy: A History of the Coalition of Provincial Organizations of the Handicapped (COPOH)." unpublished manuscript

- 1989. The Last Civil Rights Movement: Disabled Peoples International. New York: St. Martin's Press

Driedger, Diane and April D'Aubin. 1985. "So You Want to Start an Independent Living Centre?: A Winnipeg Case Study," Caliper. (December)

Driedger, Diane and Susan Gray, eds. Imprinting Our Image: An International Anthology by Women with Disabilities. Charlottetown: Gynergy

Dyke, Rand. 1991. Provincial Politics in Canada. 2nd ed. Scarborough: Prentice-Hall Canada, Inc

Eisenberg, Avigail. 1994. "The Politics of Individual and Group Difference in Canadian Jurisprudence." Canadian Journal of Political Science. 27, 1 (March): 3-21 
Enns, Henry. 1981. "The Historical Development of Attitudes Toward the Handicapped: A Framework for Change." In David S. Freeman and Barry Trute, eds., Treating Families with Special Needs. Ottawa: Alberta Association of Social Workers

Esping-Anderson, Gosta. 1985. "Power and Distributional Regimes." Politics and Society. 14, 2

“Facts about Centres," 1985. The Disability Rag, (September): 42

Farlinger, Shirley. 1995. A Million for Peace. Etobicoke: The United Church Publishing House

Farrell, Ronald A. and Victoria Lynn Swigert. 1988. Social Deviance, 3rd ed. Belmont: Wadsworth

Flora, Peter and A. Heidenheimer, eds. 1981. The Development of Welfare States in Europe and America. Transaction

Finbow, Robert. 1993. "Ideology and Institutions in North America." Canadian Journal of Political Science. 26, 4 (December): 671-697

Findlay, Sue. 1987. "Facing the State: The Politics of the Women's Movement Reconsidered." In Heather Jon Maroney and Meg Luxton, eds., Feminism and Political Economy: Women's Work, Women's Struggles. Toronto: Methuen

Frideres, James S. 1993. Native Peoples in Canada: Contemporary Conflicts. Scarborough: Prentice Hall

Gadacz, René. 1994. Rethinking Disability: New Structures, New Relationships. Edmonton: University of Alberta Press

Galipeau, Claude. 1989. "Political Parties, Interest Groups and New Social Movements." In A.G. Gagnon, ed., Canadian Parties in Transition. Toronto: Nelson

Gelb, Joyce. 1989. Feminism and Politics: A Comparative Perspective. London: University of California Press

Goffman, Erving. 1961. Asylums. New York: Anchor

- 1963. Stigma: Notes on the Maintenance of Spoiled Identity. Englewood Cliffs, NJ: Prentice-Hall

Gramson, William. 1968. Power and Discontent. Homewood: Dorsey Press 
- 1975. The Strategy of Social Protest. Homewood: Dorsey Press

Guly, Christopher. 1993. "The Means to a Cure," Disability Today. (Fall): 23-8

Gwyn, Sandra 1972. "The Great Ottawa Grant Boom." Saturday Night. 87, 10 (October): 22-24

Hahn, Harlan. 1985. "Changing Perception of Disability and the Future of Rehabilitation." In Leonard Perlman and Gary F. Austin, eds., Social Influences in Rehabilitation Planning: Bluepring for the 21st Century. Alexandria: National Rehabilitation Association

—. 1988. "The Politics of Physical Differences: Disability and Discrimination." Iournal of Social Issues. 44, 1: 39-47

- 1989. "Disability and the Reproduction of Bodily Images: The Dynamics of Human Appearances." In Jennifer Wolch and Michael Dear, eds., The Power of Ceography: How Territory Shapes Social Life. Boston: Unwin Hyman

Hasson Shlomo and David Ley. 1994. Neighbourhood Organizations and the Welfare State. Toronto: University of Toronto Press

Heaney, Thomas W. 1993. "If You Can't Beat 'Em, Join 'Em: The Professionalization of Participatory Research." In Peter Park, Mary Brydon-Miller, Budd Hall and Ted Jackson, eds., Voices of Change: Participatory Research in the United States and Canada. Toronto: OISE Press

Ingstad, Benedicte and Susan Reynolds Whyte, eds. 1995. Disability and Culture. Berkeley: University of California Press

Jenkins, J.C. 1983. "Resource Mobilization Theory and the Study of Social Movements," Annual Review of Sociology. 9: 527-553

Jennett, Christine and Randal G. Stewart, eds. 1989. Politics of the Future: The Role of Social Movements. South Melbourne: MacMillian Company of Australia

Jenson, Jane. 1991. "All the World's A Stage: Ideas, Spaces and Times in Canadian Political Economy," Studies in Political Economy. 36 (Fall): 43-71 
—. 1993. "Naming Nations: Making Nationalist Claims in Canadian Public Discourse," Canadian Review of Sociology and Anthropology. 30, 3: 337-358

—_ 1994. "Understanding Politics: Contested Concepts of Identity in Political Science." In James Bickerton and Alain-G. Gagnon, eds., Canadian Politics. 2nd ed. Peterborough: Broadview Press

Jessop, Bob. 1990. State Theory: Putting Capitalist States in their Place. University Park: The Pennsylvania State University Press

Kallen, Evelyn. 1982. "Multiculturalism: Ideology, Policy and Reality," Journal of Canadian Studies. 17, 1 (Spring): 51-63.

- 1989. Label Me Human: Minority Rights of Stigmatized Canadians. Toronto: University of Toronto Press

Kaplan, William, ed. 1993. Belonging: The Meaning and Future of Canadian Citizenship. Montreal \& Kingston: McGill-Queen's University Press

Kellough, D. Gall. 1992. "Pro-Choice Politics and Postmodernist Theory." In William Carroll, ed. Organizing Dissent: Contemporary Social Movements in Theory and Practice. Victoria: Garamond

Kinsman, Gary. 1992. "Managing AIDS Organizing: 'Consultation,' 'Partnership,' and the National AIDS Strategy." In William Carroll, ed. Organizing Dissent: Contemporary Social Movements in Theory and Practice. Victoria: Garamond Press

Kuechler, Manfred and Russell J. Dalton. 1990. “New Social Movements and the Political Order: Inducing Change for Long-term Stability?" In Russell J. Dalton, Manfred Keuchler and Wilhelm Burklin, eds., Challenging the Political Order. London: Polity Press

Lewis, Cherie S. 1994. "International Aspects of the Disability Issue." In Jack A. Nelson, ed, The Disabled, the Media, and the Information Age. Westport, Connecticut: Greenwood Press

Lord, John, Mary McGeown, Andrew Taylor and Sherri Young. 1992. More Than Just Another Human Service: Independent Living Centres in Ontario. Kitchener: Centre for Research \& Education in Human Services

Lord, John and Lynn Osborne-Way. 1987. Toward Independence and Community: A Qualitative Study of Independent Living Centres in Canada. Ottawa: Secretary of State 
McAdam, Doug. 1988. "Gender Implications of the Traditional Academic Conception of the Political." In Susan Hardey Aiken et al., eds., Changing Our Minds: Feminist Transformations of Knowledge. Albany: State University of New York Press

McAdam, Doug and Dieter Rucht. 1993. "The Cross-National Diffusion of Movement Ideas," Annals of the American Academy of Political and Social Science. 528 (July): 56-74

McColl, Mary Ann, M. Law and D. Stewart. 1993. Theoretical Basis of Occupational Therapy: An Annotated Bibliography. Thorofare, NJ: Slack

McColl, Mary Ann, Nancy Gerein and Fraser Valentine. (forthcoming). "Meeting the Challenges of Disability." In C. Christiansen and C. Baum, eds., Occupational Therapy: Overcoming Human Performance Deficits. New Jersey: Slack, Inc

McLaren, Angus. 1990. Our Own Master Race: Eugenics in Canada, 1885-1945. Toronto: McClelland \& Stewart

MacEachen, Sara Ellen. 1993. Persons United for Self-Help in Ontario: The Story of a Successful Consumer Driven Disability Advocacy Group. Toronto: PUSH

Macpherson, C.B. 1973. Democratic Theory: Essays in Retrieval. Oxford: Clarendon Press

Magnusson, Warren. 1990. “Critical Social Movements: De-Centring the State." In A.G. Gagnon and J.P. Bickerton, eds., Canadian Politics. Toronto: Broadview Press

Maguire, Patricia. 1987. Doing Participatory Research: A Feminist Approach The Centre for International Education, School of Education, University of Massachusetts

Mahon, Rianne. 1977. "Canadian Public Policy: The Unequal Structure of Representation." In Leo Panitch, ed., The Canadian State: Political Economy and Political Power. Toronto: University of Toronto Press

Mallory, J.R. 1985. "The Continuing Evolution of Canadian Constitutionalism." In Alan Cairns and Cynthia Williams, eds., Constitutionalism, Citizenship and Society in Canada. Royal Commission on Economic Union and Trade Development Prospects for Canada. Toronto: University of Toronto Press 
Marshall, T.H. 1963. "Citizenship and Social Class." In T.H. Marshall and Tom Bottomore (1992), Citizenship and Social Class. Concord, Mass: Pluto Press

Marlett, N.J., R. Gall and A. Wight-Felske, eds. 1984. Dialogue on Disability: A Canadian Perspective. Calgary: University of Calgary Press

Mathews, Robin. 1988. Canadian Identity. Ottawa: Steel Rail Publishing

Melucci, Alberto. 1988. "Social Movements and the Democratization of Everyday Life." In John Keane, ed. Civil Society and the State: New European Perspectives. London: Verso

- 1989. Nomads of the Present: Social Movements and Individual Needs in Contemporary Society. Philadelphia: Temple University Press

Mittelstaedt, Martin. 1995. "Ontario Tories slash spending by \$1.9-billion," The Globe and Mail. (July 22): A1, A4

Monsebraaten, Laurie. 1995. "Disabled group drowns in red ink." Toronto Star. (January 21)

Mooers, Colin and Alan Sears. 1992. "The 'New Social Movements' and the Withering Away of State Theory. "In William Carroll, ed. Organizing Dissent: Contemporary Social Movements in Theory and Practice. Victoria: Garamond

Morris, Aldon D, and Carol McClurg Mueller, eds. 1992. Frontiers in Social Movement Theory. New Haven, Conn: Yale University Press

Morris, Jenny. 1991. Pride Against Prejudice. London: The Women's Press

National Aboriginal Network on Disability (NAND). 1993. "Background of the National Aboriginal Network on Disability." Brief Submitted to the Royal Commission on Aboriginal Peoples

Nelson, Jack A, ed. 1994. The Disabled, the Media, and the Information Age. Westport, Connecticut: Greenwood Press

__ 1994. "Broken Images: Portrayals of Those with Disabilities in American Media." In Jack A. Nelson, ed, The Disabled, the Media, and the Information Age. Westport, Connecticut: Greenwood Press

Neufeldt, Aldred H, ed. 1993. Independent Living: An Agenda for 'the '90s. Ottawa: CAILC 
Noël, Lise. 1994. Intolerance: A General Survey. Montreal \& Kingston: McGill-Queen's University Press

Ng, Roxana. 1988. The Politics of Community Services: Immigrant Women, Class and State. Toronto: Garamond

O'Toole, Corbett Joan and Jennifer L. Bregante. 1992. "Lesbians with Disabilities," Sexuality and Disability. 10, 3: 163-172

Oberschall, Anthony. 1973. Social Conflict and Social Movements. Englewood Cliffs, NJ: Prentice-Hall

Offe, Claus. 1985. "New Social Movements: Challenging the Boundaries of Institutional Politics." Social Research. 52, 4

-1 1984. "Social Policy and the Theory of the State." In John Keane, ed., Contradicitions of the Welfare State. Boston: MIT

Oliver, Michael. 1990. The Politics of Disablement. London: MacMillan Press

Oliver, Michael and Gerry Zarb. 1989. "The Politics of Disability: a new approach." Disability, Handicap and Society. 4, 3: 221-39

Olson, Mancur. 1965. The Logic of Collective Action: Public Goods and the Theory of Groups. Cambridge: Harvard University Press

Pal, Leslie A. 1989. "Identity, citizenship, and mobilization: The Nationalities Branch and World War Two." Canadian Public Administration. 32, 3 (Fall): 407-426

- 1993. Interests of State: The Politics of Language, Multiculturalism, and Feminism in Canada. Kingston: McGill-Queen's University Press

Park, Peter. 1993. "What Is Participatory Research? A Theoretical and Methodological Perspective." In Peter Park, Mary Brydon-Miller, Budd Hall and Ted Jackson, eds., Voices of Change: Participatory Research in the United States and Canada. Toronto: OISE Press

Park, Peter, Mary Brydon-Miller, Budd Hall and Ted Jackson, eds. 1993. Voices of Change: Participatory Research in the United States and Canada. Toronto: OISE Press 
Pathway to Integration: Final Report, Mainstream 1992. 1993. Report to the Ministers of Social Services on The Federal/Provincial/Territorial Review of Services Affecting Canadians with Disabilities. (author and publisher not listed)

Pateman, Carole. 1988. "The Patriarchal Welfare State." In A. Gutmann, ed., Democracy and the Welfare State. Princeton: Princeton University Press

-1 1989. The Disorder of Women: Democracy, Feminism and Political Theory. Stanford: Stanford University Press

Philip, M. Nourbese. 1992. Frontiers: Essays and Writings on Racism and Culture. Stratford: The Mercury Press

Phillips, Susan D. 1991a. "How Ottawa Blends: Shifting Government Relationships with Interest Groups." In Frances Abele, ed., How Ottawa Spends 1991-1992: The Politics of Fragmentation. Ottawa: Carleton University Press

- 1991b. "Meaning and Structure in Social Movements: Mapping the Network of National Canadian Women's Organizations." Canadian Iournal of Political Science. 24, 4 (December): 755-782

- 1992. "New Social Movements and Unequal Representation: The Challenge of Influencing Public Policy." In Alain-G. Gagnon and A. Brian Tanguay, eds., Democracy with Justice. Ottawa: Carleton University Press

-1994. "New Social Movements in Canadian Politics: On Fighting and Starting Fires." In James Bickerton and Alain-G. Gagnon, eds., Canadian Politics. 2nd ed. Peterborough: Broadview Press

Price Waterhouse. 1991. Secretary of State. Evaluation of the Disabled Persons Participation Program (DPPP). Final Report. Ottawa: Price Waterhouse (March)

Prince, Michael J. 1992. "Touching Us All: International Context, National Policies, and the Integration of Canadians with Disabilities." In Frances Abele, ed., How Ottawa Spends: The Politics of Competitiveness. Ottawa: Carleton University Press

Pross, Paul. 1992. Group Politics and Public Policy. 2nd ed. Toronto: Oxford University Press 
Radford, John P. 1994. "Intellectual Disability and the Heritage of Modernity," In Marcia H. Rioux and Michael Bach, eds., Disability Is Not Measles: New Research Paradigm in Disability. North York: The Roeher Institute

Rankin, Pauline. 1995. "Matters of Place and Space: A Locational Analysis of Women's Movements in Ontario." Paper presented at the Annual Conference of the Association for Canadian Studies in the United States. Seattle, Washington. (October 15-20)

Rankin, Pauline and Jill Vickers. forthcoming. "Locating Women's Politics." In Manon Tremblay and Caroline Andrew, eds., Women and Politics Representation. Ottawa: University of Ottawa Press

Ratner, R.S. 1992. "New Movements, New Theory, New Possibilities? Reflections on Counter-Hegemony Today." In William Carroll, ed. Organizing Dissent: Contemporary Social Movements in Theory and Practice. Victoria: Garamond

Rice, James J. 1995. "Redesigning Welfare: The Abandonment of a National Commitment." In Susan Phillips, ed., How Ottawa Spends 1995-96. Ottawa: Carleton University Press

Rioux, Marcia H. 1994. "New Research Directions and Paradigms: Disability is Not Measles." In Marcia H. Rioux and Michael Bach, eds., Disability Is Not Measles: New Research Paradigm in Disability. North York: The Roeher Institute

Rioux, Marcia H. and Michael Bach, eds. 1994. Disability Is Not Measles: New Reseach Paradigms in Disability. North York: The Roeher Institute

Roberts, Ed. 1995. "Goodbye, Ed," Mouth: The Voice of Disability. 6, 1 (MayJune)

Safilios-Rothschild, Constantina. 1970. The Sociology and Social Psychology of Disability and Rehabilitation. New York: Random House

Sargent, Lyman. 1972. New Left Thought: An Introduction. Berkeley: University of California Press

Sayers, Sohnya, Anders Stephanson, Stanley Aronowitz and Fredric Jameson, eds. 1984. The 60s Without Apology. Minneapolis: University of Minnesota Press

Scotch, Richard K. 1984. From Goodwill to Civil Rights: Transforming Federal Disability Policy. Philadelphia: Temple University Press 
—_. 1988. "Disability as the Basis for a Social Movement: Advocacy and the Politics of Definition," Lournal of Social Issues. 44, 1: 159-172

Shaw, Barrett. 1994. The Ragged Edge: The Disability Experience from the Pages of the First Fifteen Years of the Disability Rag. Louisville: The Advocado Press

Simmons, Harvey G. 1982. From Asylum to Welfare. Downsview: National Institute on Mental Retardation

Splane, Richard B. 1965. Social Welfare in Ontario 1791-1893. Toronto: University of Toronto Press

Stasiulis, Daiva and Radha Jhappan. 1995. "The Fractious Politics of a Settler Society: Canada." In Daiva Stasiulis and Nira Yuval-Davis, eds., Unsettling Settler Societies: Articulations of Gender, Race, Ethnicity and Class. London: Sage Publications

Stone, Deborah A. 1984. The Disabled State. Philadelphia: Temple University Press

Tarrow, Sindey. 1989. Struggle, Politics, and Reform: Collective Action, Social Movements, and Cycles of Protest. Ithaca, NY: Center for International Studies, Cornell University

Tate, Denise G., Robert L. Jarvis and Gerald D. Juhr. 1979. “International Efforts in Independent Living," Archives of Physical Medicine and Rehabilitation. 60 (October): 462-67

Taylor, Charles. 1992. Multiculturalism and "The Politics of Recognition". Princeton, New Jersey: Princeton University Press

Teodori, Massimo, ed. 1969. The New Left: A Documentary Story. New York: Bobbs-Merrill Company

Tiily, Charles. 1978. From Mobilization to Revolution. Reading, Mass: Addison-Wesley

- 1985. "Models and Realities of Popular Collective Action," Social Research. 524

Toughill, Kelly. 1995. "Thousands facing loss of disability benefits," The Toronto Star. (October 7): A1, A14 
Touraine, Alain. 1981. The Voice and the Eye: An Analysis of Social Movements. Cambridge: Cambridge University Press

- 1988. Return of the Actor: Social Theory in Postindustrial Society. Minneapolis: University of Minnesota Press

Valentine, Fraser. 1994. The Canadian Independent Living Movement: An Historical Overview. Ottawa: CAILC

- (forthcoming). "The Political Growth of the Canadian Independent Living Movement." In Gary Woodill and Ray Haines, eds., The History of Disabilities: International Perspectives. New York: Garland Publishing

Verville, Richard E. 1979. "Federal Legislative History of Independent Living Programs." Archives of Physical Medicine and Rehabilitation. 60 (October): 447-51

Vickers, Jill. 1986. “Equality Seeking in a Cold Climate." In Lynn Smith, Gisèle Côté-Harper, Robin Elliot and Magda Seydegart, eds., Righting the Balance: Canada's New Equality Rights. Saskatoon: The Canadian Human Rights Reporter Inc

- 1988. Getting Things Done: Women's Views of Their Involvement in Political Life. Ottawa/Paris: CRIAW and UNESCO

—. 1989. "Issues and Strategies." In Caroline Andrew, ed., Getting the Word Out: Communicating Feminist Research. Ottawa: University of Ottawa Press

- 1991. "Bending the Iron Law of Oligarchy: Debates on the Feminization of the Political Process in the English Canadian Women's Movement, 1970-1988." In Jeri Dawn Wine and Janice L. Ristock, eds., Women and Social Change: Feminist Activism in Canada. Toronto: James Lorimer and Company

1992. "The Intellectual Origins of the Women's Movements in Canada." In Constance Backhouse and David H. Flaherty, eds., Challenging Times: The Women's Movement in Canada and the United States. Kingston: McGill-Queen's University Press

1995. "The 'New Politics' in Ontario: Grounding 'Social' Movement Theory and Research in Canadian Studies." Paper presented at the Annual Conference of the Association for Canadian Studies in the United States. Seattle, Washington. (October 15-20) 
Vickers, Jill, Pauline Rankin and Christine Appelle. 1993. Politics as if Women Mattered: A Political Analysis of the National Action Committee on the Status of Women. Toronto: University of Toronto Press

Voet, Rian. 1994. "Women as Citizens: A Feminist Debate," Australian Feminist Studies. 19 (Autumn): 61-77

Walzer, Michael. 1992. "Comment." In Charles Taylor, Multiculturalism and the "Politics of Recognition". Princeton: Princeton University Press

Weir, Fred. 1995. "Canadian project aims to help disabled," Ottawa Citizen. (July 10)

Weir, Lorna. 1993. "Limitations of New Social Movement Analysis," $\underline{\text { Studies }}$ in Political Economy. 40 (Spring): 73-102

Weir, M., A. Shola Orloff and T. Skocpol. 1988. The Politics of Social Policy in the United States. Princeton

Whyte, Susan Reynolds and Benedicte Ingstad. 1995. "Disability and Culture: An Overview." In Benedicte Ingstad and Susan Reynolds Whyte, eds., Disability and Culture. Berkeley: University of California Press

Williams, Clifford J. 1984. A History of the Ontario Ministry of Community and Social Services, 1930-1980: Decades of Service. Toronto: Ministry of Community and Social Services

Williams, Cynthia. 1985. "The Changing Nature of Citizen Rights." In Alan Cairns and Cynthia Williams, eds., Constitutionalism, Citizenship and Society in Canada. The Royal Commission on Economic Union and Trade Development Prospects for Canada. Toronto: University of Toronto Press

Williams, Gareth H. 1983. "The Movement for Independent Living: An Evaluation and Critique," Social Science and Medicine. 1, 15: 1003-10

Wolch, Jennifer R. 1989. "The shadow state: transformations in the voluntary sector." In Jennifer Wolch and Michael Dear, eds., The Power of Geography: How Territory Shapes Social Life. Boston: Unwin Hyman

Woodill, Gary. 1992. Independent Living \& Participation in Research: A Critical Analysis. Toronto: Centre for Independent Living in Toronto

Woodward, John R. 1995. "What's Happening to the CILs?" The Disability Rag. (May/June): 21-4 
1995. "The ADA at 5," The Disability Rag. (July/August): 27-31

World Health Organization. 1980. International Classification of

Impairments, Disabilities and Handicaps. Geneva: WHO

Young, Iris Marion. 1990. Justice and the Politics of Difference. Princeton:

Princeton University Press

Zald, M and J.D. McCarthy, eds. 1979. The Dynamics of Social Movements. Cambridge: Winthrop Publishers

- 1987. Social Movements in an Organizational Society. New Brunswick, NJ: Transaction Books

Zola, Irving Kenneth. 1994. "Towards Inclusion: The Role of People with Disabilities in Policy and Research Issues in the United States-A Historical and Political Analysis." In Marcia H. Rioux and Michael Bach, eds., Disability Is Not Measles: New Research Paradigm in Disability. North York: The Roeher Institute 